May 8, 1900.

\title{
W. T. Blanford, Esq., LL.D., F.R.S., Vice-President, in the Chair.
}

The Secretary read the following report on the additions to the Society's Menagerie during the month of April 1900 :-

The total number of registered additions to the Society's Menagerie during the month of April was 120 , of which 41 were by presentation, 52 by purchase, 15 were received on deposit, and 12 were born in the Menagerie. The total number of departures during the same period, by death and removals, was 103 .

Amongst the additions attention may be called to :-

1. A young Lyre-bird (Menura superba), presented by Messrs. Carrick and Fry on April 12th. Of this well-known Australian type no specimen has been received by the Society since 1876 . The present example is immature, and may be either a female or a young male, the tail-feathers being not yet developed.

2. A Ural Owl (Syrnium uralense) obtained by purchase April 24 th. This fine Owl of North-eastern Europe has not been previously represented in the Society's collection.

Mr. Sclater exhibited a specimen of a male Reedbuck (Cervicapra), which had been mounted by Messrs. Rowland Ward \& Co., for Mr. Ewart S. Grogan, F.Z.S. It had been already exhibited as a skin to the Society by Mr. R. Lydekker, on May 2nd, $1899^{1}$. The specimen was of about the same size and dimensions as the Common Reedbuck (C. arundinum $)^{2}$, but differed entirely in its pale grizzled grey colour above and white under surface, the anterior surface of all four limbs being of a dark rich brown. It had been supposed by Mr. Lydekker, and other good authorities who had examined this specimen, that the animal might be an albino or pale-coloured variety of the Common Reedbuck; but, after studying the specimen carefully, Mr. Sclater had come to a different conclusion, and considered it to be referable to a new species, which, at the request of $\mathrm{Mr}$. Grogan, he proposed to call Cervicapra thomasince, with the following characters :-

Cervicapra thomasine, sp. nov. (Plate XXVI.)

C. quoad formam C. arundinum fere similis, sed colore albo, in dorso cineraceo et pedibus antice fulvo-brunneis, ut videtur, satis diversa : alt. ad humeros 35 poll.

$H a b$. in ripis Laci Nyasæ, Afr. or.

The specimen exhibited had been obtained by Mr. Grogan on the Songwé River, about six miles from its entrance into Lake

${ }^{1}$ See P. Z. S. 1899 , p. 555.

2 Book of Ant. vol. ii. p. 157, pl. xliii.

Proc. Zoot. Soc.-1900, No. XXIX. 
Nyasa in December 1898, during the journey from the Cape to Cairo, of which Mr. Grogan had lately given an account to the Royal Geographical Society (see 'Geographical Journal,' xvi. p. 164). Mr. Grogan had been informed of the existence of a herd of four of these animals on the Songwé, and on proceeding to the spot indicated by his informant, had succeeded in shooting the present specimen, which he met with while grazing in a patch of grass near the river. Mr. Grogan had been told that a similar animal had been seen at Fort Johnston at the south end of the Lake, and that a specimen had likewise been met with on the shores of Lake Nyasa about 40 miles from its north end. Altogether Mr. Grogan had heard of eight specimens of this animal.

Mr. C. Davies Sherborn, F.Z.S., called attention to the progress of his 'Index Animalium,' commenced in 1889, which would contain an alphabetical list of all names used in Zoology from 1758 to 1900. The first portion, now approaching completion, was that for the years 1758 to 1800 inclusive. This part would contain about 60,000 entries; the whole of the slips were already in alphabetical order, and had had the duplicate entries eliminated. About six months' more work would be required to check the generic names. Mr. Sherborn, who is the Recorder under the British Association Committee, stated that he had been able to purchase no less than 250 volumes dealing with systematic zoology and dated before 1800 , copies of which were not previously to be found in England. All of these volumes had now been incorporated in the Libraries of public institutions in this country. Some of these volumes were unique, and most of them of considerable rarity.

Mr. R. Lydekker called attention to the following misprint in the notice of his exhibition of the head of a Swamp-Deer (P.Z. S. 1899 , p. 829), where the word 'Thameny' in the bottom line should read 'Thameng'; also to an error in the lettering of the plate in his paper on "The Dental Formula of the Marsupial and Placental Carnivora," where in fig. 4, " $p p .2$ " should be read " $m p .2$."

A paper was read by Mr. J. S. Budgett, F.Z.S., "On some Points in the Anatomy of Polypterus," of which the following is an abstract:-

Having obtained a large amount of material of both the species of Polypterus found in the Gambia, in the spring of 1899, I thought it advisable to attempt to fill up some gaps in our knowledge of the anatomy of this most interesting of tishes.

Though much work has been done by many zoologists in this direction, there are many points in which the descriptions already 
published of the anatomy of Polypterus are either deficient or inaccurate.

In the present paper, I have described in detail the urinogenital system of the male and female Polypterus, together with the later stages of the development of these organs. I have also added observations upon the vascular system, the external gills, the abdominal pores, the anal fin, and the skull.

In obtaining my material, I was aided by a grant of $£ 50$ from the Balfour Fund of the University of Cambridge. The work has been done in Mr. Adam Sedgwick's laboratory. To Mr. Sedgwick, Mr. Graham Kerr, and Prof. Howes my thanks are due for much help and advice.

The Male Organs.-In the adult male Polypterus a ridge of testicular tubules extends on either side the entire length of the body, but is only functional towards the anterior end of the ridge, where it swells out to form a conspicuous lobulated testis. A longitudinal duct lies at the base of the whole ridge ventral to and parallel with the ureter. Into this duct the tubules of the testis and of the testis-ridge open by very numerous short ducts.

The duct on either side leaves the testis-ridge as the "vas deferens," and running backwards in the same sheath of connective tissue as the ureter, opens upon a papilla into the urinogenital sinus just before the latter opens to the exterior. The spermatozoa are very small, about the length of the long axis of a red bloodcorpuscle, slightly swollen anteriorly, tapering posteriorly.

The duct of the testis-ridge is developed before the tubules of either the testis or testis-ridge, but in a specimen $9 \mathrm{~cm}$. in length ends blindly in the wall of the ureter.

The Female Organs. - The funnel-like openings of the oviduct into the body-cavity were mentioned and figured by Joh. Müller and again by Hyrtl.

According to Hyrtl, the two oviducts unite to form a urinogenital sinus, into which the two ureters open by a common middorsal aperture.

I find, however, that the ureters are dilated posteriorly, lying closely approximated to one another, but not communicating except immediately before opening to the exterior. Shortly before they open to the exterior, the oviducts open into their lateral walls precisely as do the vasa deferentia in the male.

Further, in the young female, $9 \mathrm{~cm}$. in length, the course of these ducts has exactly the same relation to the ureter as in the male, only that the oviducts are considerably more dilated in the female. The ducts at this stage, like those of the male, end blindly in the lateral wall of the ureter. The peritoneal opening of the oviduct is already open at this early stage.

The ovary of Polypterus develops as a genital ridge lying on either side along the ventral surface of the kidney, from which it is separated posteriorly by the oviduct. The ovary becomes early divided into numerous compartments, on the external walls of which the ova are developed. 
With increase in size of the ova, the external wall bulges out into great folds between the septa, while the internal wall remains a smooth sheet of peritoneum. As the ova develop, they become deeply pigmented upon the pole of the ovum, which is attached to the original outer wall of the ovary. It thus comes about that when ripe, through the smooth internal wall of the ovary only the colourless poles are seen, while through the external much-folded wall only the pigmented poles are seen. It has been stated that the outer wall of the ovary of Polypterus is without a covering of peritoneum; it will be seen from the description that this is not strictly correct.

General considerations on the Structure and Growth of the Urinogenital Organs.-I have shown that in the male Polypterus there are no connections between the testis and the kidney by which the latter could carry off the products of the testis, as is the case in Lepidosteus and perhaps some other Ganoids.

I have shown also that the arrangement of the ducts of the genital glands is very similar in male and female, and that in the larva this resemblance amounts almost to identity. From the early development of these ducts, and the similarity in the male and female, I regard the condition found in Polypterus as the primitive arrangement; and that in all cases where connections are found between the testis-tubules and the tubules of the kidney, they are either inherited along a divergent line of ascent, or, as in the case of Lepidosteus, secondarily acquired.

Abdominal Pores.-In both male and female, abdominal pores are present in Polypterus. These pores are acquired late in life, after the Polypterus is $9 \mathrm{~cm}$. in length.

Anal Fin.-Traquair has already noted in Calamoichthys that the males have an enlarged anal fin. This difference is, in the breeding-season, one also of form as well as size. The anal-fin muscle in the male increases in size so much that the viscera in the posterior end of the cœlom are displaced. Fertilization is probably not internal, as has been suggested by Leydig.

External Gill.-The structure of the external gills is precisely that of larval Dipnoi and Amphibia.

Hyrtl supposed the external gill of Polypterus to be homologous with the endodermal pseudobranch of Acipenser. From a study of the blood-supply, I conclude that it is rather homologous with the external ectodermal gill of larval Dipnoi and Amphibia, which have properly an external and an internal gill to each visceral arch.

Vascular System.-In this preliminary abstract of my paper, I will merely state that my investigations lead me to agree with Pollard in regarding the arterial system of Polypterus as only comparable with the primitive Chlamydoselachus and embryo Selachians, where from each gill-arch a single efferent vessel unites with a median precardial aorta.

Cranium.-I find that there is an important specific difference in the form of the sphenoid of the two species $P$. senegalus and 
P. lapradei, a difference which Bridge observed in two specimens of Polypterus and which he attributed to great range of variation.

This paper will be published in full in the Society's 'Transactions.'

The following papers were read:-

\section{A List of the Batrachians and Reptiles of the Gaboon (French Congo), with Descriptions of new Genera and species. By G. A. Boulenger, F.R.S.}

[Received March 20, 1900.]

\section{(Plates XXVII.-XXXII.)}

Mr. G. L. Bates, who has been stationed for some time on the Benito River, north of the Gaboon River, between 20 and 30 miles inland from the coast, has been so kind as to collect Batrachians and Reptiles for the British Museum, and so lucky as to discover, especially among the former, a number of new or interesting forms, on some of which I have already reported ${ }^{1}$. Whilst describing the new forms of which an account is given in this paper, it appeared to me useful to compile a complete list of all the species on record from the Gaboon district-viz., the part of West Africa situated between Camaroons and Loango, in the French Congo ${ }^{2}$. Such a stock-taking seemed to me particularly useful with reference to the work on the distribution of species in the Congo basin, with which I am now engaged. I must observe, however, that I am convinced that the list will have to be increased by the addition of a number of widely distributed species which are known both north and south of the Gaboon district, and which will, no doubt, be found when more extensive collections are made; but I have introduced the names of such species ouly of which I have seen examples from the district, or which have been recorded on reliable authority.

Only five contributions dealing specially with the Batrachians and Reptiles of the Gaboon district have been published so far :-

DumérIL, A._ “ Note sur les Reptiles du Gabon.” Rev. et Mag. de Zool. 1856, pp. 369-377, 417-424, 460-470, 553-562, pls. xx. \& xxi.-The new species described in this paper have been redescribed and mostly figured in the same author's "Reptiles de l'Afrique occidentale," Arch. du Mus. x. 1859, pp. 137-240, pls. xiii.-xviii.

1 Ann. \& Mag. N. H. (7) iii. 1899, pp. 274, 276, and iv. 1899, p. 122.

2 The term Gaboon is here taken in the old sense. I do not know on what authority the Gold Coast is included in the Gaboon Country by Giinther, P.Z.S. 1899, pp. $716 \& 721$. 
Halloweld, E.- "Notice of a Collection of Reptiles from the Gaboon County, West Africa, recently presented to the Academy of Natural Sciences of Philadelphia by Dr. Henry A. Ford." Proc. Acad. Philad. 1857, pp. 48-72.

Peters, W., and Buchноцz, R.- " Zweite Mitthejlung über die in West Africa gesammelten Amphibien.” Mon. Berl. Ac. 1867, pp. 117-123. [Mostly from the Gaboon and Ogowe.]

GüNTHer, A.- " Report on a Collection of Reptiles and Fishes made by Miss M. H. Kingsley during her Travels on the Ogowe River and in Old Calabar." Ann. \& Mag. N. H. (6) xvii. 1896 , pp. $261-285$.

Mocquard, F.- "Sur une Collection de Reptiles recuillie par M. Haug à Lambaréné." Bull. Soc. Philom. (8) ix. 1897, pp. 5-20.

For the nomenclature and synonyms I must refer the reader to the British Museum Catalogues. I have added references to publications issued since the appearance of these general works.

Mr. Bates's discoveries have enriched herpetology with 5 new genera and 13 new species, some of which are of special morphological interest. The discovery of Hymenochirus and Cardioglossa has extended our knowledge of geographical distribution by adding African representatives to the families Pipida and Dendrobatida, the former having been based on the single SouthAmerican genus Pipa, the latter being hitherto regarded as characteristic of Tropical America and Madagascar.

I wish to record my thanks to the Board of Curators of the Philadelphia Academy of Natural Sciences for the loan of type specimens described in 1857 by the late Dr. Hallowell.

\section{BATRACHIA.}

\section{APODA.}

1. Uraotyphlus seraphini A. Dum.

$H a b$. Gaboon.

2. Herpele squalostoma Stutchbury.

Hab. Gaboon.

\section{ECAUDATA.}

\section{DACTYLETHRID $\pi$.}

\section{Xenopus calcaratus Ptrs.}

$H a b$. West Africa, from Liberia to the Congo.

One of the specimens collected by Mr. Bates on the Benito River has been prepared as a skeleton. There are only seven præcaudal vertebræ, the first being formed by the fusion of two (as is clearly proved by the large nerve-foramen in front of the diapophysis). 


\section{PIPIDA.}

4. Hymenochirus boettaeri Tornier.

Xenopus boettgeri, Tornier, Kriechth. Deutsch-Ost-Afr. p. 163, fig. (1896).

Hymenochirus boettgeri, Bouleng. Ann. \& Mag. N. H. (6) xviii. 1896 , p. 420, and (7) iv. 1899, p. 122 ; Ridewood, Journ. Linn. Soc., Zool. xxvii. 1900 , p. 454 , pl. xxxi.

$H a b$. German East Africa; Gaboon.

In recently recording the occurrence of this extraordinary Batrachian on the Benito River, I have pointed out that the absence of teeth necessitates its removal from the Dactylethridce to the Pipida. My notes on the skeleton have been corrected and supplemented by Dr. Ridewood in the paper quoted above, dealing with the hyoid and larynx and the carpus.

\section{BUFONIDE.}

כ. Bufo tuberosus Gthr.

$H a b$. Fernando Po, Camaroons, Gaboon.

Several specimens were obtained on the Benito River by Mr. Bates. The upper parts are not always uniformly coloured; they are sometimes handsomely spotted or marbled with darker brown, and a yellow or crimson vertebral line is often present.

6. Bufo regularis Reuss.

$H a b$. The whole of Africa with the exception of Barbary. I have, however, not myself examined specimens from the Gaboon and there were none in the collection made by Mr. Bates.

7. Bufo latifrons, sp. n. (Plate XXVII. fig. 1.)

Crown without bony ridges; snout short, blunt; interorbital space slightly concave, broader than the upper eyelid; tympanum distinct, three-fifths the diameter of the eye. First finger much longer than second; toes half-webbed, with single subarticular tubercles; two rather small metatarsal tubercles; a tarsal fold. The tarso-metatarsal articulation reaches the anterior border of the eye. Upper parts with irregular warts, some of which may be conical; parotoids elliptic, feebly prominent, rather indistinct. Olive-brown above, with or without a yellowish vertebral line, with more or less symmetrical black markings; limbs with dark cross-bars; bright pink spots on the back of the thighs; lower parts dirty white, throat greyish, breast with small greyish spots.

From snout to vent 73 millim.

Three specimens, females and young, from the Benito River (G. L. Bates).

This species stands very near to $B$. regularis. It is distinguished by the broader interorbital region, the smaller tympanum, and the feebly prominent parotoid glands. 


\section{Bufo superciliaris Blgr.}

Bufo superciliaris, Bouleng. Proc. Zool. Soc. 1887, p. 565.

Bufo lavissimus, Wemer, Sitzb. Bayer. Ak. xxvii. 1897, p. 212, and Verh. zool.-bot. Ges. Wien, xlviii. 1898, p. 202, pl. ii. fig. 1.

This curious Toad was described from young specimens collected by Sir H. H. Johnston in the Rio del Rey district, Camaroons. Adult specimens have been redescribed by Werner under the name of B. lavissimus, from Camaroons. A young specimen is in Mr. Bates's collection from the Benito River. I have also examined a fine specimen, measuring about 120 millim. from snout to vent, from the Congo Free State.

\section{Bufo gracilipes Blgr.}

Bufo gracilipes, Blgr. Ann. \& Mag. N. H. (7) iii. 1899, p. 276, pl. xii. fig. 2.

I have recently described this Toad from a single specimen from the Benito River, collected by Mr. Bates. I have now examined several specimens, and have to add that the tarso-metatarsal articulation may fail to reach beyond the anterior border of the eye, that the toes are one-third webbed in breeding specimens, that the parotoid glands may be more distinct than in the type specimen, narrow and shorter than the head, and that the male is provided with an internal subgular vocal sac and brown nuptial asperities on the inner side of the two inner fingers. Limbs with dark cross-bars. The largest male measures 30 millim. from snout to vent, the largest female 40 .

\section{Nectophryne afra Ptrs.}

Originally described from Camaroons. Two specimens ( $\delta$ $q$ ) are in Mr. Bates's collection from the Benito River.

Fig. 1.
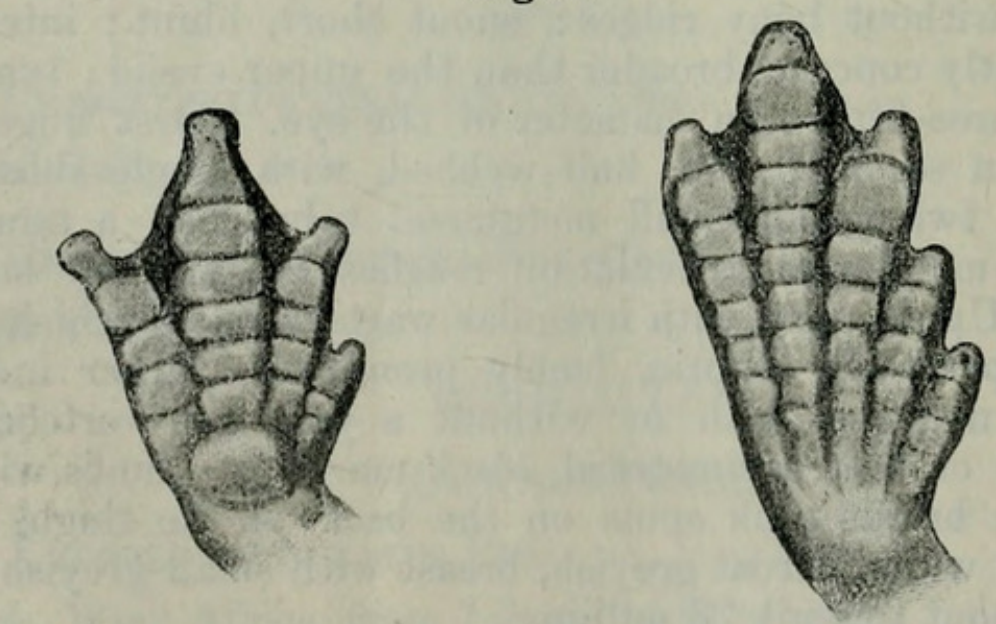

Hand and foot of Nectophryne afra, showing the subarticular tubercles of the fingers and toes.

The subarticular tubercles of the fingers and of the toes are much developed, and flattened into overlapping pads which bear a 
close resemblance and are no doubt functionally analogous with the subdigital lamellæ of the seansorial Geckos. Such a structure had not been observed before in any Batrachian. Buchholz and Peters have not alluded to it otherwise than by mentioning "dunkle Querlinien unter den Zehen," which I believe to be the result of an optical delusion caused by the lamellæ to which attention is now drawn.

The male, which is devoid of vocal sacs, measures only 17 millim. from snout to vent; the female measures 21 .

\section{RANIDE.}

\section{Rana crassipes Ptrs.}

This species is known from Camaroons and the Gaboon. I have examined 10 specimens collected by $\mathrm{Mr}$. Bates on the Benito River, the largest measuring 63 millim. from snout to vent.

As pointed out by Günther (Ann. \& Mag. N. H. [6] xvii. 1896, p. 266), the vomerine teeth are sometimes absent; this is the case in three of Mr. Bates's specimens. When present, they form two very small groups just behind the level of the choanæ. The tympanum is more or less distinct, measuring three-fourths or fourth-fifths the diameter of the eye. The colour of the upper parts varies from greyish olive or purplish brown to blackish, with or without very indistinct darker and lighter spots or marblings; dark cross-bars on limbs usually irregular, sometimes absent; lower parts white, throat often spotted or marbled with dark brown.

\section{Rana subsigillata A. Dum.}

This species, which has been well figured by A. Duméril, is known from Old Calabar, Camaroons, and the Gaboon. Several specimens were collected by Mr. Bates on the Benito River, the largest measuring 88 millim. from snout to vent.

The species is remarkable for its long head without eanthi rostrales, and its short limbs, the tibio-tarsal articulation reaching the tympanum; the diameter of the latter is two-thirds to threefourths that of the eye. The upper parts are of a dark brown, but the sides of the head and body and the fore limbs are often tinged with bright carmine. The lower parts, in the young, are olive, with close-set round pale yellow spots on the throat and belly; with age, the dark colour between the spots becomes reduced to a network, which may even almost entirely disappear. Some specimens have a rather indistinct flat round gland under each thigh, as in most species of the genus Mantidactylus.

\section{Rana feviplicata Werner.}

Rana mascareniensis, var, cequiplicata, Werner, Verh. z.-b. Ges. Wien, xlyiii. 1898, p. 192.

Vomerine teeth in two short oblique series commencing from the inner front edges of the choanæ. Head moderate, as long as broad or a little longer than broad; snout pointed, longer than the 
diameter of the orbit; canthus rostralis distinct; loreal region deeply concave; nostril midway between the eye and the end of the snout; interorbital space nearly as broad as the upper eyelid; tympanum distinct, two-thirds or three-fourths the diameter of the eye. Fingers moderate, obtusely pointed, first not extending beyond second; toes broadly webbed, the web reaching the extremity of the third and fifth toes, but leaving two phalanges of the fourth toe free; subarticular tubercles moderate; a very small, oval, inner metatarsal tubercle, no outer tubercle. The tibio-tarsal articulation reaches far beyond the tip of the snout; tibia more than two-thirds the length of head and body. Skin more or less distinctly granular above, with numerous, interrupted, glandular, longitudinal folds on the back; a glandular fold from beneath the eye to the shoulder. Olive-brown above, with small dark spots, with or without a broad whitish or pink vertebral band; usually a dark cross-bar between the eye; a black canthal streak and a black temporal spot; tympanum reddish brown; limbs with dark cross-bars; hinder side of thighs black, spotted or marbled with white or pink; a series of black spots on the lower jaw ; throat and belly yellow, immaculate. Male with two black external vocal vesicles projecting through two slits below the lower jaw.

From snout to vent 50 millim.

Five specimens from the Benito River are in Mr. Bates's collection. Dr. Werner's specimens were from Camaroons.

Closely allied to $R$. mascareniensis; differs in the more extensively webbed toes and the more numerous, interrupted folds along the back.

\section{Rana mascareniensis D. \& B.}

Hab. Egypt, Tropical Africa, Seychelles, Madagascar, Mascarenes. The Gaboon specimens belong to the var. bibronii Hallow. (superciliaris Gthr.), with longer snout and longer hind limbs. The head is longer than broad, and the tibio-tarsal articulation reaches beyond the end of the snout.

\section{Rana albolabris Hallow.}

$H a b$. Fernando Po, Camaroons, Gaboon, Lower Congo.

Females grow to a length of 93 millim. from snout to vent. In such large specimens the dorso-lateral glandular fold becomes more indistinct, the tibio-tarsal articulation reaches the eye or between the eye and the end of the snout, the first finger does not extend beyond the second, and the white border to the upper lip, whence the species derives its name, disappears more or less completely.

\section{ScotoblePs, g. n.}

Pupil vertical. Tongue free and deeply notched behind. Vomerine teeth. Tympanum distinct. Fingers free; toes webbed. Outer metatarsals narrowly separated by web. Omo- 
sternum and sternum with a bony style. Terminal phalanges simple, obtuse.

This genus may be defined as Rana with a vertical pupil.

16. Scotobleps gabonicus, sp. n. (Plate XXVIII. fig. 1.)

Vomerine teeth in two small groups on a line with the posterior borders of the choanæ. Head rather large, as long as broad; snout obtusely pointed, with feeble canthus rostralis; loreal region slightly concave; nostril equally distant from the eye and the end of the snout; eye large ; interorbital space narrower than the upper eyelid; tympanum not quite half the diameter of the eye. Fingers and toes' moderately elongate, with slightly swollen tips and very strong subarticular tubercles; first finger extending as far as second; toes half-webbed; an oval inner metatarsal tubercle. The tibio-tarsal articulation reaches the nostril. Skin smooth, or with small flat warts on the back. Olive-brown above, with small blackish spots; a dark cross-band between the eyes; upper lip with blackish vertical bars, the one below the anterior third of the eye extending on the lower lip ; limbs with dark crossbars ; lower parts white. Male with internal vocal sacs.

From snout to vent 57 millim.

Three specimens from the Benito River (G. L. Bates).

\section{Petropedetes newtoni Bocage.}

Tympanoceros newtonii, Bocage, Jorn. Sc. Lisb. (2) iii. 1895, p. 270 , and iv. 1895 , p. 18, pl. - .

Males differ from females in the larger tympanum, which is larger than the eye, and from the centre of which a horn-like dermal tubercle projects, in the presence of a long spine on the inner side of the first finger, and in the greater size of a large flat oval gland on the lower side of the thigh.

Several specimens were obtained on the Benito River by Mr. Bates. The specimens described by Barboza du Bocage are from Fernando Po.

The genus Petropedetes Reichenow (Arch. f. Nat. 1874, p. 290) is nearly related to Cornufer, but differs in the division of the dermal pad on the upper surface of the digital expansions by a short distal groove, giving it a cordiform appearance. The males are remarkable for the large glands under the thighs, which are absent or feebly developed in the females. In addition to the type species and the one now referred to, the genus embraces Cornufer johnstoni Boulenger, from the Rio del Rey, Camaroons. The three species may be distinguished as follows :-

$P$. cameronensis Reich. Toes half-webbed; tympanum half diameter of eye.

P. johnstoni, Blgr. Toes with a mere rudiment of web; tympanum half diameter of eye.

$P$. newtoni Bocage. Toes with a mere rudiment of web; tympanum more than half diameter of eye; male with a spine on the inner finger and a dermal tubercle on the tympanum. 
18. Phrynobatrachus auritus, sp. n. (Plate XXVIII. fig. 2.)

Tongue with a free conical papilla in the middle. Habit slender. Head moderate, as long as broad; snout pointed, projecting beyond the mouth, with angular canthus and nearly vertical loreal region; nostril equally distant from the eye and the end of the snout; interorbital space narrower than the upper eyelid; tympanum distinct, measuring nearly half the diameter of the eye. First finger as long as second; toes two-thirds webbed; tips of fingers and toes dilated into small disks ; subarticular tubercles small ; two small metatarsal tubercles; a very small tubercle not far from the latter, on the inner side of the tarsus. The tibio-tarsal articulation reaches the tip of the snout. Skin smooth, or with very small warts above; a narrow glandular fold on each side of the back from the eyes to the sacral region, the two folds converging on the scapular region; a similar fold from the eye to the shoulder. Greyish or reddish brown above, darker on the middle of the back, with or without a filiform light vertebral line, which is continued along the middle of the upper surface of the thigh and the inner side of the leg; glandular folds edged with blackish; a few round black spots may be present on the pelvic region; limbs with rather indistinct darker cross-bars; hinder side of thighs blackish brown, edged with whitish above near the vent; inner side of legs also blackish brown; lower parts white, with small brownish spots on the throat and breast in the female; the throat blackish in the male. Male with an internal subgular vocal sac.

From snout to vent 37 millim.

Three specimens from the Benito River (G. L. Bates).

The distinct tympanum distinguishes this species from $P$. plicatus Gthr., to which it bears some resemblance.

19. Phrinobatrachus latirostris, sp. n. (Plate XXVIII. fig. 3.)

Tongue with a free conical papilla in the middle. Habit moderately slender. Head moderate, as long as broad; snout short, rounded ; canthus rostralis distinct; loreal region concave ; nostril equally distant from the eye and the end of the snout; interorbital space as broad as the upper eyelid ; tympanum distinct, measuring three-fifths the diameter of the eye. Fingers and toes moderate, the tips dilated into small disks ; first finger not extending as far as second; toes half-webbed; a small, oval, inner metatarsal tubercle. The tibio-tarsal articulation reaches between the eye and the end of the snout. Skin smooth; a slight curved fold behind the eye, converging towards its fellow on the scapular region. Dark greybrown above; a dark triangular spot between the eyes; glandular folds dark-edged; upper lip lighter, with dark vertical bars ; lower lip dark brown in the male, with a series of small white spots; limbs with dark cross-bars; anal region blackish, edged with whitish above; throat grey in the male, white, spotted with brown, in the female; belly and lower surface of limbs white, breast spotted with brown, Male with an internal subgular vocal sac. 
From snout to vent 30 millim.

A single male specimen from the Benito River (G. L. Bates).

A smaller female specimen from Lambarene, collected by Miss Kingsley, has been referred by Günther to Cornufer johnstoni.

20. Arthroleptis africanus Hallow.

Heteroglossa africana, Hallow. Proc. Ac. Philad. 1857, p. 64 ; Cope, Proc. Ac. Philad. 1862, p. 343. (1882).

Arthroleptis? africanus, Bouleng. Cat. Batr. Ecaud. p. 119

Arthroleptis gabonensis, Mocquard, Bull. Soc. Philom. (8) ix. 1897 , p. 17.

Thanks to the kindness of Dr. Chapman, Chairman of the Board of Curators of the Museum of the Academy of Sciences of Philadelphia, I have been able to examine the type specimen from the Gaboon, preserved in that Institution, and compare it with two specimens, male and female, collected by Mr. Bates on the Benito River.

Tongue with a free conical papilla in the middle. Head rather large, as long as broad; snout obtusely pointed, with feeble canthus and concave loreal region; interorbital space narrower than the upper eyelid ; tympanum distinct, two-thirds the diameter of the eye. Fingers and toes moderate, the tips swollen into small disks; first finger not extending beyond second; toes with a short but very distinct web ; two metatarsal tubercles, inner oval, outer round, subconical; a small tubercle on the tarsus, near the inner metatarsal tubercle. The tibio-tarsal articulation reaches the nostril. Upper parts with small flat warts; a feeble curved fold on each side of the scapular region. Dark brown above; limbs with darker cross-bars; blackish vertical bars on the sides of the head; white beneath, limbs spotted with brown; throat spotted with brown in the female, entirely black in the male, which is provided with an internal vocal sac.

From snout to vent 30 millim.

21. Arthroleptis variabilis Matschie.

Arthroleptis dispar (non Peters, 1870), Peters, Mon. Berl. Ac. 1875 , p. 210 , pl. iii. figs. $1-3$.

Arthroleptis variabilis, Matschie, Sitzb. Ges. nat. Fr. Berl. 1893, p. 173 ; Bocage, Jorn. Sc. Lisb. (2) iv. 1895, p. 18; Werner, Verh. zool.-bot. Ges. Wien, xlviii. 1898, p. 193.

Hab. Fernando Po, Camaroons, Gaboon.

22. Arthroleptis macrodactylus Blgr.

Arthroleptis macrodactylus, Bouleng. Cat. Batr. Ecaud. p. 117, pl. xi. fig. 5 (1882), and Zool. Rec. 1885, Rept. p. 23 ; Günth. Proc. Zool. Soc. 1893, p. 620.

Arthroleptis bivittatus, F. Müll. Verh. nat. Ges. Basel, vii. 1885, p. 671 , pl. ix. figs. $\mathrm{k}-\mathrm{l}$.

Hab. Gaboon, Tumbo Id. (Gulf of Guinea), Nyassaland. 


\section{Arthroleptis inguinalis, sp. n. (Plate XXVII. fig. 2.)}

Tongue without conical papilla. Head moderate, as long as broad; snout rounded; canthus rostralis obtuse ; loreal region concave; interorbital space as broad as the upper eyelid; tympanum distinct, three-fifths to two-thirds the diameter of the eye. Fingers and toes rather elongate, slender, the tips merely swollen; subarticular tubercles very prominent; first finger not extending beyond second; toes practically free, the rudiment of web being very indistinct; a rather large, very prominent, oval, compressed inner metatarsal tubercle; no outer metatarsal tubercle; no tarsal tubercle. The tibio-tarsal articulation reaches the eye or between the eye and the end of the snout. Skin smooth. Coloration very variable : greyish or brownish above, uniform or spotted or freckled with darker, or with dark symmetrical markings; a black canthal and temporal streak; a more or less distinct dark spot or short oblique band on the groin; limbs with dark spots or bars; lower parts white, throat usually freckled with brown. Male with an internal vocal sac.

From snout to vent 30 millim.

Numerous specimens from the Benito River (G. L. Bates).

\section{Gampsosteonyx, g. n.}

Pupil vertical. Tongue free and feebly notched behind. Vomerine teeth. Tympanum distinct. Fingers and toes free, the tips slightly swollen; terminal phalange of all but the inner toe a sharp curved claw, projecting through a slit on the lower surface of the extremity of the toe. Outer metatarsals bound together. Omosternum and sternum with a bony style.

The projecting, non-retractile bony claw, uncovered with a horny sheath, which arms the toes with the exception of the hallux, is a feature unique, so far, not only among Batrachians but among Vertebrates. The only other instance I know of bone being exposed through the skin in Vertebrates higher than Fishes is to be found in the ends of the ribs of Molge (Pleurodeles) waltlii Mich. and Tylototriton andersonii Blgr.

\section{Gampsosteonyx batesi, sp. n. (Plate XXIX.)}

Vomerine teeth in two small round groups between the choanæ. Head large, much broader than long; snout broadly rounded, with short canthi and very oblique, slightly concave lores; nostril equally distant from the eye and the end of the snout; eye large ; interorbital space as broad as the upper eyelid; tympanum very distinct, oval, little smaller than the eye. First finger longer than second, nearly as long as third; subarticular tubercles of fingers and toes feeble; a small, oval, inner metatarsal tubercle. The tibiotarsal articulation reaches the eye. Skin smooth and shiny; a glandular fold above the tympanum. Dark purplish brown above, white beneath; a black canthal and temporal streak; a black transverse line between the eyes; two dark bars on the upper lip, 
the first under the nostril, the second below the anterior third of the eye; limbs with rather indistinct dark cross-bars; lower surface of crus and tarsus dark brown.

From snout to vent 70 millim.

A single specimen from the Benito River (G. L. Bates).

\section{Trichobatrachus, g. $\mathrm{n}$.}

Pupil vertical. Tongue subcordiform, free and notched behind. Vomerine teeth. Tympanum distinct. Fingers free; toes webbed. Outer metatarsals bound together. Omosternum with a bony style; sternum a cartilaginous plate, without style. Terminal phalanges simple, obtuse.

To these characters might be added the villose dermal papillæ which cover some parts of the body, whence the name proposed for this new genus, were it not that I suspect it to be a mere seasonal peculiarity ; far from being a nuptial attribute of the males, as one might have been inclined to suppose from analogy with various Fishes, the character is more strongly developed in the female than in the male.

\section{Trichobatrachus robustus, sp. n. (Plate XXX.)}

General appearance suggestive of Rana liebigi Gthr. Vomerine teeth in two short transverse series between the rather large choanæ. Head larger, broader than long, much depressed; snout very short, rounded, with distinct canthi and very oblique, slightly concave lores; nostril slightly nearer the eye than the end of the snout; interorbital space a little broader than the upper eyelid; tympanum moderately distinct, half the diameter of the eye. Limbs robust; tips of digits slightly swollen; first finger much longer than second, as long as third; toes half-webbed; subarticular tubercles large; a feebly prominent, elongate, inner metatarsal tubercle. The tibio-tarsal articulation reaches the eye. Skin smooth; sides of body, back of thighs, and a stripe along the upper surface of the latter with hair-like papillæ, more developed in the female than in the male. Olive-brown above; a darker, black-edged broad band along the back, fading away behind and sharply defined in front by a black cross-bar between the eyes; a black canthal and temporal streak; sides of body and limbs blackish ; lower parts white, female with brown dots on the throat. Male with a pair of internal vocal sacs, and with three short ridges (two longitudinal and one transverse) of small horny black spines on the inner side of the first finger.

From snout to vent 110 millim.

Two specimens ( $\sigma^{*}+$ ) from the Benito River (G. L. Bates).

\section{Dilobates, $\mathrm{g} . \mathrm{n}$.}

Pupil vertical. Tongue subcordiform, free and notched behind. Vomerine teeth. Tympanum distinct. Fingers free; toes nearly free, with a slight rudiment of web. Outer metatarsals bound 
together. Omosternum and sternum small, cartilaginous. Terminal phalanges simple, obtuse.

26. Dilobates platycephalus, sp. n. (Plate XXVII. fig. 3.)

Vomerine teeth in two small groups on a line with the posterior borders of the choanæ. Head very broad, much broader than the body, depressed, with very oblique lores and temples; snout rounded; canthus rostralis distinct; a loreal concavity; nostril equally distant from the eye and the end of the snout; interorbital space as broad as the upper eyelid; tympanum almost as large as the eye. Fingers and toes rather short, obtuse; first finger extending beyond second; subarticular tubercles moderate; a small, oval, inner metatarsal tubercle. Hind limb slender; the tibiotarsal articulation reaches the anterior border of the eye. Skin smooth. Olive above, with small black spots; a dark cross-band between the eves, preceded by a yellowish one; sides of head yellowish, with two dark bars, the first below the nostril, the second below the anterior half of the eye ; fore limb yellowish ; limbs with blackish transverse spots ; lower parts white.

From snout to vent 26 millim.

A single specimen from the Benito River (G. L. Bates).

27. Rappia fimbriolata Buchh. \& Ptrs.

Hyperolius fimbriolatus, Buchholz \& Peters, Mon. Berl. Ac. 1876, p. 121.

Rappia fimbriolata, Boettg. Ber. Senck. Ges. 1887-88, p. 96.

Hab. Ogowe and Loango.

28. Rappia marmorata Rapp.

$H a b$. Tropical and South Africa.

29. Rappia ocellata Gthr.

Hab. Fernando Po to Angola.

30. Rappia fuscigula Bocage.

Hab. Gaboon to Angola.

31. Rappia tuberculata Mocq. p. 18.

Rappia tuberculata, Mocquard, Bull. Soc. Philom. (8) ix. 1897,

Hab. Ogowe.

32. Rappia phantastica Blgr.

Rappia phantastica, Bouleng. Ann. \& Mag. N. H. (7) iii. 1899, p. 274 , pl. xi. fig. 2 .

Hab. Benito River (G. L. Bates).

33. Rappia platycers, sp. n. (Plate XXVII. fig. 4.)

Head rather large, as long as broad, much depressed; snout rounded; loreal region oblique; interorbital space broader than 
the upper eyelid; tympanum hidden. Outer fingers one-fourth webbed; toes two-thirds webbed; disks rather large. The tibiotarsal articulation reaches the eye. Skin smooth, faintly areolate on the belly. Pale brownish above, with a large blackish-brown marking with indentations extending from between the eyes to the sacral region; sides of head and body and upper surface of legs blackish brown; a whitish spot on the leg above the tibio-tarsal articulation; upper surface of thigh whitish, with a narrow dark brown streak; lower parts white.

From snout to vent 29 millim.

Two specimens from the Benito River (G. L. Bates).

34. Rappia pusilla Cope.

Hab. Niger Delta to Gaboon.

35. Megalixalus fornasinit Bianc.

Megalixalus fornasinii, Werner, Verb. zool.-bot. Ges. Wien, xlviii. 1898 , p. 195.

Hyperolius dorsalis, Peters, Mon. Berl. Ac. 1875, p. 206, pl. i. fig. 2.

Hyperolius leptosomus, Peters, op. cit. 1877, pl. 619, pl. - fig. 5 .

Megalixalus leptosomus, Mocq. Bull. Soc. Philom. (8) ix. 1897, p. 19.

Hab. Gold Coast to Congo, Nyassaland, East Africa from the Zanzibar Coast to Delagoa Bay.

36. Chiromantis rufescens Ptrs.

$H a b$. Camaroons, Gaboon.

37. Hylambates Rufus Reichen.

Hab. Fernando Po, Camaroons, Gaboon.

38. Hylaybates brevirostris Werner.

Hylambates brevirostris, Werner, Verh. zool.-bot. Ges. Wien, xlviii. 1898 , p. 199 , pl. ii. figs. 5 \& 6 .

In addition to the characters given by Werner from Camaroons specimens, this well-marked species is easily distinguished from $H$. rufus by the more dorsal position of the tympanum. The only specimen obtained by Mr. Bates on the Benito River is uniform purplish above.

\section{Dendrobatide.}

\section{Cardioglossa, g. n.}

Pupil horizontal. Tongue large, cordiform, deeply notched behind. Tympanum distinct. Fingers and toes free, the tips dilated into regular disks. Outer metatarsals united. Omosternum with a slender bony style; sternum a small cartilaginous plate, without bony style. Terminal phalanges T-shaped.

Proc. Zool. Soc.-1900, No. XXX. 
The family Dendrobatida, which may be defined as Ranidae without teeth, was previously represented by two genera only : Dendrobates, from Tropical America, with the tongue elongate and entire and without bony style to the sternum; and Mantella, from Madagascar, with the tongue elongate and nicked behind and with a bony style to the sternum.

39. Chardioglossa gracilis, sp. n.

Fig. 2.

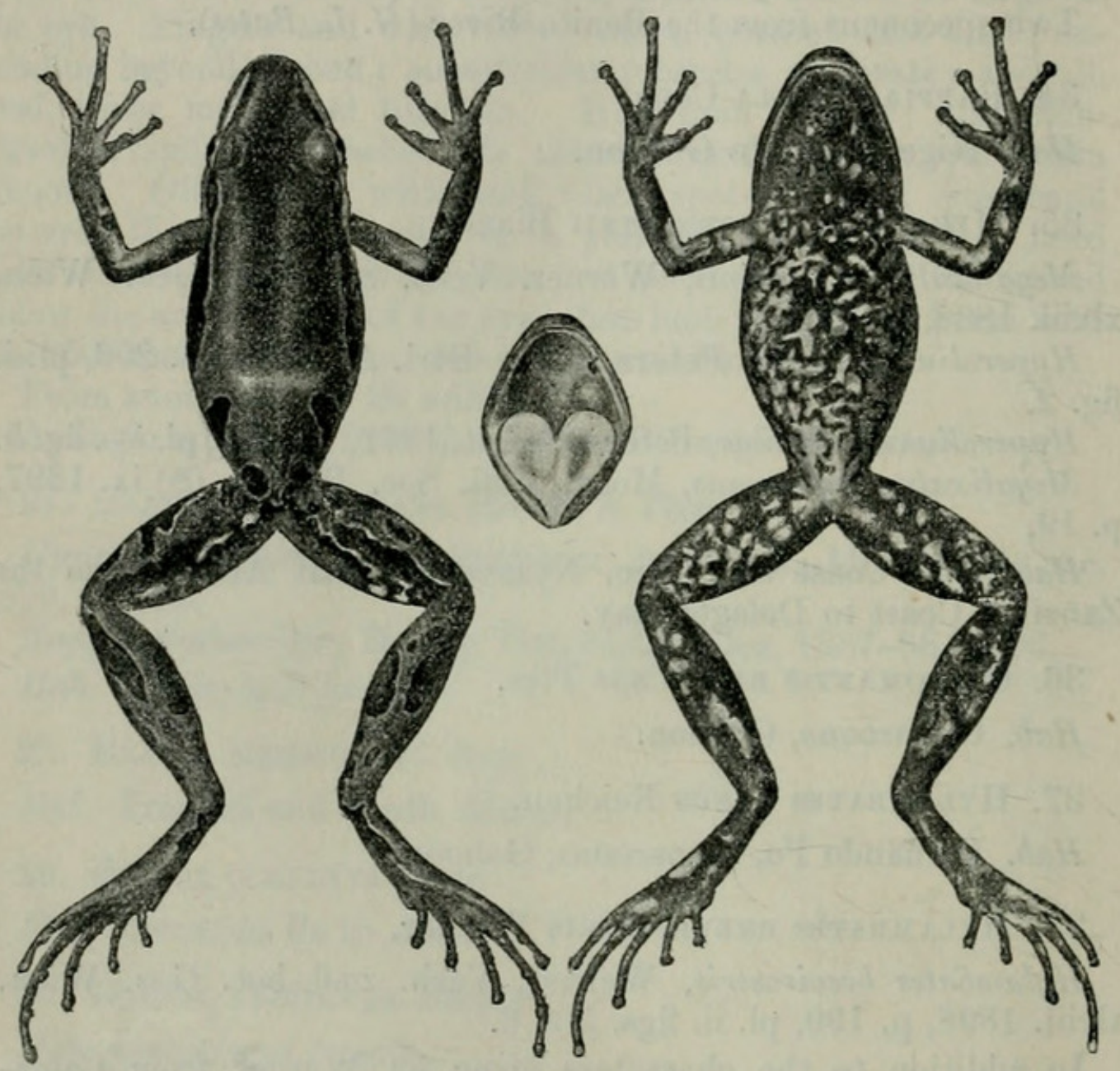

Cardioglossa gracilis.

Head much depressed, a little longer than broad; snout longer than the orbit, truncate at the end, scarcely projecting beyond the mouth; canthus rostralis distinct; loreal region concave; nostril near the end of the snout; eye rather small; interorbital space much broader than the upper eyelid; tympanum very distinct, two-thirds or three-fourths the diameter of the eye. Fingers and toes long and slender, the tips dilated into small disks; subarticular tubercles small but very prominent; first finger not extending quite as far as second; a rather prominent, moderately large, oval inner metatarsal tubercle. The tibio-tarsal articulation reaches the tip of the snout or a little beyond. Dark brown above and beneath; a black band, edged beneath with white, extends on each 
side from the nostril to halfway down the side of the body, passing through the eye and tympanum, and widening behind; this band followed by a large black inguinal spot; dark symmetrical markings on the limbs, those on the front and back of the thighs black, edged with white; lower surfaces spotted or marbled with white. Male with internal vocal sacs.

From snout to vent 37 millim.

Several specimens from the Benito River (G. L. Bates).

\section{REPTILIA.}

\section{CHELONIA.}

\section{Pelomedusid}

1. Sternotherus gabonensis A. Dum.

$H a b$. Gaboon; Angola.

2. Sternotherus derbianus Gray.

Hab. Cape Verde to Angola.

\section{TESTUdinide.}

3. Cinixys erosa Schweigg.

$H a b$. Gold Coast to Gaboou.

4. Cinixys homeana Bell.

$H a b$. Cape Verde to Gaboon.

\section{TRIONYCHIDÆ.}

5. Trionyx triunguis Forsk.

Hab. Tropical Africa, Nile, Syria.

6. Cycloderma aubryi A. Dum.

$H a b$. Gaboon.

\section{EMYDOSAURIA.}

Crocodilid $Æ$.

7. Crocodilus cataphracitus Cuv.

$H a b$. Senegal to Congo.

8. Crocodinus niloticus Laur.

$H a b$. Nile and Senegal to Cape of Good Hope; Madagascar; Syria.

9. Osteolames tetraspis Cope.

$H a b$. Sierra Leone to Gaboon. 


\section{LACERTILIA.}

Geckonid .

10. Hemidacty lus mabuia Moreau.

? $H$. angulatus Hallow.

$H a b$. Tropical Africa, Madagascar, South America.

11. Hemidactylus echinus O'Shaugh.

Hab. Camaroons, Gaboon.

12. Hemidactylus fasciatus Gray.

$H a b$. Gold Coast to Gaboon.

Through an oversight, this species appears in Günther's list of the Reptiles collected by Miss Kingsley as Gymnodactylus fasciatus, which is the name of an American Gecko.

13. Hemidactylus bocagin Blgr.

Hab. Gaboon, Angola.

14. Hemidactylus richardsoni Gray.

Hemidactylus richardsonii, J. G. Fischer, Jahrb. Hamb. wiss. Aust. v. 1888, p. 49, pl. iv. fig. 10.

Hab. Gaboon.

15. Ligodactylus capensis Smith.

Hab. Gaboon (Benito River) and Lake Tanganyika to Natal.

Agamide.

16. Agama colonorum Daud.

Hab. Senegambia to Angola, Somaliland, and Uganda.

\section{VARANIDE.}

17. Varanus niloticus L.

Hab. Tropical and South Africa, Egypt.

AmpHisbenide.

18. Monopeltis dumerilit Strauch.

Hab. Gaboon.

19. Monopeltis magnipartita Ptrs.

Hab. Gaboon.

20. Monopeltis koppenfelsi Strauch.

$H a b$. Gaboon. 


\section{LACERTIDA.}

21. Poromera fordi Hallow. (Plate XXXI. fig. 1.)

Tachydromus fordii, Hallow. Proc. Ac. Philad. 1857, p. 48.

Poromera fordii, Bouleng. Cat. Liz. iii. p. 6 (1887); Günth. Ann. \& Mag. N. H. (6) xvii. 1896, p. 264.

Poromera haugi, Mocquard, Bull. Soc. Philom. (8) ix. 1896, p. 6.

Hallowell's description is faulty in several points, as I have been able to satisfy myself through inspection of the type specimen $\left(\sigma^{*}\right)$ kindly sent to me from Philadelphia.

The ventral shields are in 10 longitudinal rows, not in 6 . The large anal shield is bordered by a semicircle of keeled scales, a larger one on each side, connected by a series of 6.12 femoral pores on one side, 13 on the other. In addition to this specimen, I have examined one from Lambarene, on the Ogowe, collected by Miss Kingsley and described by Dr. Günther, and seven procured by Mr. Bates on the Benito River. The dorsal shields are in 6 or 8 longitudinal, the ventrals in 8 or 10 longitudinal and 23 to 26 transverse series. The collar contains 12 to 14 shields. Males have a large, smooth præanal shield, bordered by a series of 6 or 8 keeled scales; females have the whole præanal region covered with keeled scales. 11 to 13 femoral pores on each side. Two superposed postnasals; 4 to 6 upper labials anterior to the subocular. Dark olive aliove, turning to bronze or copper-colour posteriorly ; two light dorsal streaks, bright bluish white anteriorly; beneath greenish white in front, salmon-pink behind. The largest specimen measures 65 millim. from snout to vent.

Only known from the Gaboon district.

22. Lacerta echinata Cope.

Hab. Liberia to Loango.

23. Holaspis guentheri Gray.

$H a b$. Tropical Africa, from the Gold Coast and the coast of Zanzibar to Angola and the Zambesi.

\section{Gerrhosauridæ.}

24. Gerrhosaurus nigrolineatus Hallow.

$H a b$. Gaboon to Angola.

\section{SCINCID}

25. Mabuia Raddonil Gray.

$H a b$. Sierra Leone to Congo.

26. Mabuia batesi, sp. n. (Plate XXXI. fig. 2.)

Snout short, obtuse, much depressed. Lower eyelid with a 
large transparent disk. Nostril behind the suture between the rostral and the first labial; a post-nasal; anterior loreal not touching the first labial; supranasals widely separated from each other, the rostral forming a broad suture with the frontonasal; latter nearly twice as broad as long; præfrontals forming a short median suture; frontal as long as the fronto-parietals and interparietal together, in contact with the first and second supraoculars; four supraoculars, second largest; seven superciliaries, first largest; frontoparietals distinct, twice as long as the interparietal; parietals short, twice as broad as long, forming a suture behind the interparietal; no nuchals; fifth and sixth upper labials largest and below the eye. Ear-opening smaller than the transparent palpebral disk; two small obtuse lobules on its anterior border. Scales smooth, smallest on the sides, 32 round the middle of the body. The hind limb reaches the elbow of the adpressed fore limb. Digits short; subdigital lamellæ obtusely keeled. Tail slightly compressed, nearly once and a half the length of the head and body, Dark olive above, with widely separated bluish spots preceded by blackish ones, forming two longitudinal series on the back; a black canthal streak; sides of the neck and axilla lineolate black and white, with some black spots; lower parts white.

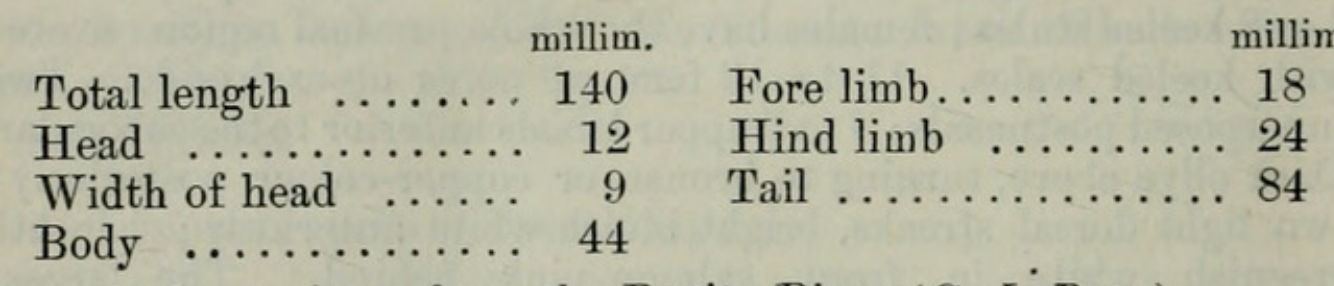

A single specimen from the Benito River (G. L. Bates).

27. Lygosoma reichenovir Peters.

Lygosoma reichenovii, Mocquard, Bull. Soc. Philom. (8) ix. 1897, p. 8.

Hab. Camaroons ; Lower Ogowe.

28. Lygosoma fernandi Burton.

Hab. Fernando Po to Congo.

Anelytropide.

29. Feylinia currori Gray.

Hab. Sierra Leone to Angola.

\section{RHIPTOGLOSSA.}

Chameleontide.

30. Cham eleon quilensis Bocage.

Chamaleon parvilobus, Bouleng. Cat. Liz. iii. p. 449. Hab. Camaroons to South Africa. 
31. Chamaleon gracilis Hallow.

$H a b$. Tropical Africa, from the Gold Coast and Somaliland to Angola and Lake Tanganyika.

32. Chamaleon dilepis Leach.

$H a b$. Gaboon and Somaliland to Angola, Mashonaland, and Mozambique.

33. Chamaleon oweni Gray.

Hab. Camaroons to Gaboon.

34. Chameleon oristatus Stutchb.

Hab. Calabar to Gaboon.

35. Rhampholeon SPECTRUM Buchh.

Rhampholeon spectrum, Mocquard, Bull. Soc. Philom. (8) ix. 1897 , p. 5.

Hab. Camaroons; Lower Ogowe.

\section{OPHIDIA.}

TYPHLOPIDÆ.

36. Typhlops punctatus Leach.

$H a b$. West Africa, from the Gambia to Angola; Central Africa.

37. Typhlops cencus A. Dum.

Hab. Sierra Leone, Gaboon.

BoIDe.

38. Python sebe L.

$H a b$. Tropical and South Africa.

39. Calabaria Reinhardti Schleg.

$H a b$. Liberia to Congo.

Colubride.

40. Tropidonotes fuliginoides Gthr.

Hab. Gold Coast to Congo; Central Africa; Mozambique.

41. Tropidonotus olivaceus Ptrs.

Hab. Sudan to Congo and Mozambique.

42. Hydrathiops Melanogaster Gthr.

Hab. Camaroons to Congo. 
43. Gonionotophis brussauxi Mocq.

Gonionotophis brussauxi, Mocquard, Bull. Soc. Philom. (8) ix. 1897, p. 13.

Gonionotus vossii, Boettg. Zool. Anz. 1892, p. 418.

$H a b$. Camaroons to Congo.

44. Bothrophthalmus lineatus Ptrs.

Hub. Liberia to Congo; Central A frica.

45. Boodon virgatus Hallow.

Hab. Gold Coast to Gaboon.

46. Boodon lineatus D. \& B.

Hab. Tropical and South Africa.

47. Boodon olivaceus A. Dum.

$H a b$. Niger to Congo.

48. Lycophidium laterale Hallow.

$H a b$. Gold Coast to Gaboon.

49. Lycophidium fasciatum Gthr.

$H a b$. Sierra Leone to Gaboon.

50. Hormonotus modestus D. \& B.

$H a b$. Gold Coast to Loango.

51. Simocephadus Capensis Smith.

$H a b$. Gaboon, Nyassaland, South-east Africa.

52. Simocephalus guirali Moeq.

$H a b$. Camaroons to Loango.

53. Chlorophis irregularis Leach.

$H a b$. Tropical Africa from the Gambia and British East Africa to Angola and Mozambique.

54. Chlorophis heterodermus Hallow.

Hab. Sierra Leone to Congo.

55. Philothamnes semitariegatus Smith.

$H a b$. Tropical and South Africa.

56. Philothamnes dorsalis Bocage.

$H a b$. Gaboon to Angola.

57. Gastropyxis smaragdinus Schleg.

$H a b$. Liberia to Angola. 
58. Hapsidophris lineata Fisch.

$H a b$. Liberia to Congo.

59. Rhamiophis methiops Gthr.

$H a b$. Liberia to Gaboon.

60. Thrasops flavigularis Hallow.

$H a b$. Sierra Leone to Congo.

61. Grayia smythi Leach.

$H a b$. Liberia to Angola.

1 have re-examined all the specimens in the British Museum in the light of the remarks recently made by Prof. Barboza du Bocage (Herp. d'Angola et du Congo, pp. $102 \&$ 104) and by Dr. Mocquard (Bull. Soc. Philom. [8] ix. 1897, p. 9), and although I admit the possibility of several species being confounded under the name of $G$. smyihi, I am unable to separate them into two by means of the characters pointed out by these authorities. This is obvious from the following tabulation of the shields and scales in the specimens examined by me:-

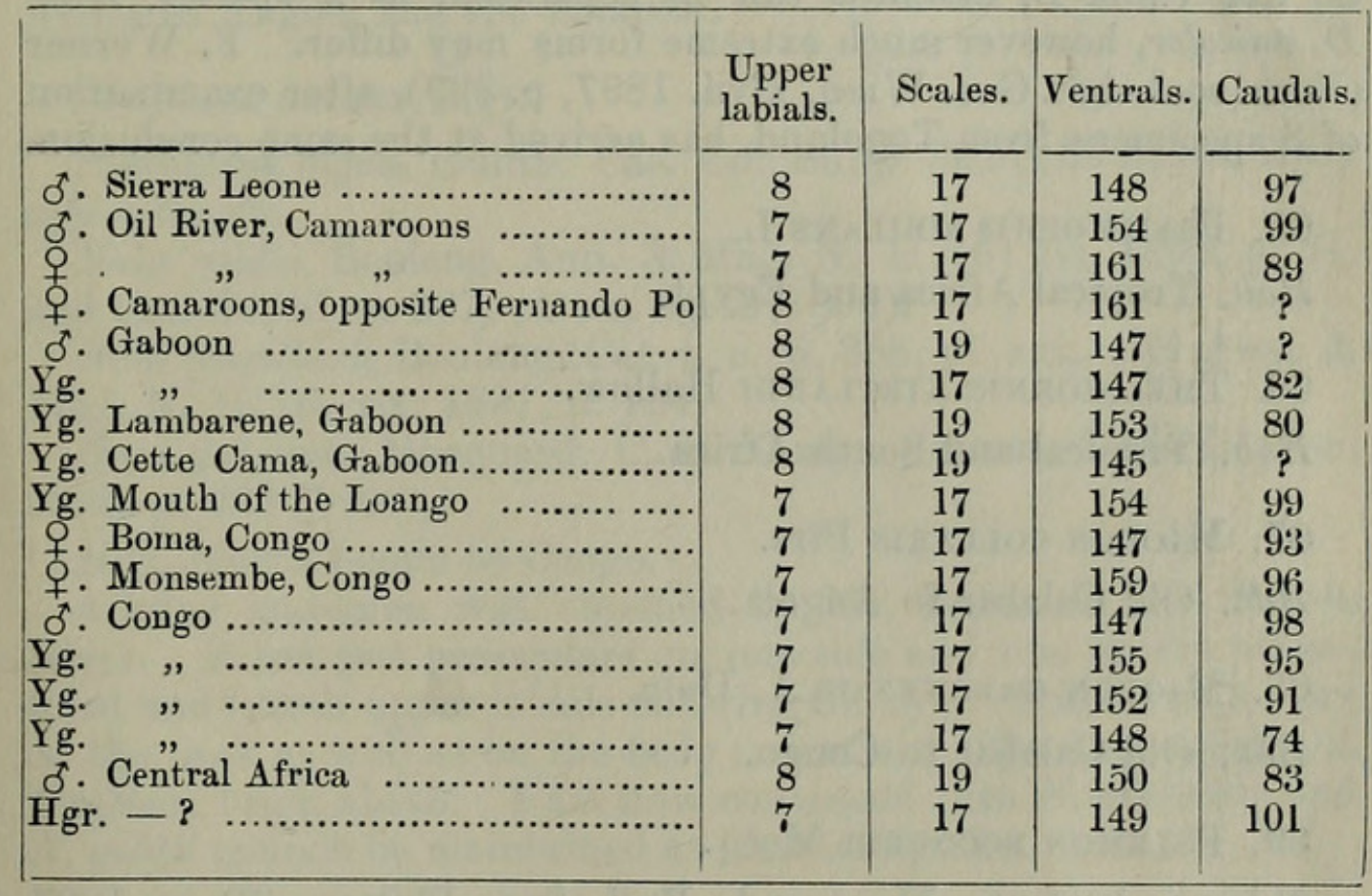

Mocquard gives 19 as the number of scales in G. ornata = furcata, but the types of both these supposed species are described as having only 17. A much larger material than was accessible to Bocage, Mocquard, and myself is required before the variations of the forms of this genus can be properly understood.

62. Dipsadomorphus pulverulentus Fisch.

$H a b$. Liberia to Angola. 
63. Dipsadomorphus blandingin Hallow.

Hab. West Africa, from the Senegal to the Congo ; Zanzibar.

\section{Dipsadoboa unicolor Gthr.}

$H a b$. Sierra Leone to Gaboon.

A single specimen ( 9 , V. 192 ; C. 58 ) was sent by Mr. Bates from the Benito River. It is blackish above and white beneath, Eight upper labials, third and fourth entering the eye. A smaller specimen, collected by Miss Kingsley at Lambarene, noticed by Günther under the name of $D$. assimilis Matschie, is brown above with ill-defined darker cross-bars; eight upper labials, fourth and fifth entering the eye on the left side, third, fourth, and fifth on the left. The typical $D$. unicolor Gthr., green above, with nine upper labials, fifth and sixth entering the eye, is not confined to the island of Fernando Po, as Günther was inclined to believe; the British Museum has recently acquired a similar, but larger, specimen (total length 710 millim.; tail 145) from Sierra Leone. Anoplodipsas viridis Ptrs., of which Heterurus bicolor Jan is a strict synonym, is green above and has eight upper labials, fourth and fifth entering the eye. There is thus no correspondence between the colour and the number of the labials. I therefore do not think $D$. assimilis can be separated, as a species, from D. unicolor, however much extreme forms may differ. F. Werner (Verh. zool.-bot. Ges. Wien, xlvii. 1897, p. 399), after examination of 8 specimens from Togoland, has arrived at the same conclusion.

65. Psammophis sibilians L.

$H a b$. Tropical Africa and Egypt.

66. Thelotornis kirtlandi Hallow.

$H a b$. Tropical and South Africa.

67. Miodon collaris Ptrs.

Hab. Old Calabar to Angola.

68. Miodon gabonensis A. Dum.

$H a b$. Old Calabar to Congo.

69. Polemon bocourti Mocq.

Polemon bocourti, Mocquard, Bull. Soc. Philom. (8) ix. 1897, p. 13.

This species differs from $P$. barthi Jan in having two postoculars and a lower number of ventral shields (178-202). A single specimen from Lambarene (V.171 ; C. 24) in Miss Kingsley's collection has been referred by Günther to $P$. barthi.

70. Elapops modestus Gthr.

Hab. Liberia to Congo. 
71. Boulengerina annulata Buchh. \& Ptrs. (Plate XXXII.) Naja annulata, Buchh. \& Peters, Mon. Berl. Ac. 1876, p. 419; Mocquard, Bull. Soc. Philom. (7) xi. 1887, p. 84 ; Bocage, Herp. Angola, p. 137 (1895).

Aspidelaps bocagii, Sauvage, Bull. Soc. Zool. France, 1884, p. 205 , pl. vi. fig. 2 .

Boulengerina annulata, Mocquard, Bull. Soc. Philom. (8) ix. 1897, p. 14.

Two perfectly typical young specimens (V. $227-230$; C. 72,70 ) were obtained on the Benito River by Mr. Bates. The only difference, apart from the markings, between this species and B. stormsi Dollo resides in the number of scales (23 instead of 21), and it is quite possible the two may have to be united when we become acquainted with a larger number of specimens.

$H a b$. Gaboon to Congo.

72. Elapechis guentheri Bocage.

Hab. Gaboon to Angola; Nyassaland.

73. Naia melanoleuca Hallow.

$H a b$. Tropical Africa, from the Gambia and British East Africa to Angola and the Zambesi.

74. NaIa goldiI Blgr.

Pseudohaje nigra, Günth. Cat. Col. Sn. p. 222 (1858), nec Naia nigra, Smith.

Naia goldii, Bouleng. Ann. \& Mag. N. H. (6) xvi. 1895, p. 34, and Cat. Sn. iii. p. 387, pl. xx. fig. 2 (1896).

Naia guentheri, Bouleng. Cat. t. c. p. 388 , pl. xxi., and Ann. \& Mag. N. H. (6) xix. 1897 , p. 154.

Naia yakomae, Mocquard, C. R. Congr. Intern. Zool. Leyden, 1895 , p. 233 (1896).

$H a b$. Sierra Leone to Congo.

A large specimen was obtained by $\mathrm{Mr}$. Bates on the Benito River. It has two præoculars on one side and one on the other; third and fourth upper labials entering the eye. Scales in 15 rows on the neck as well as on the body ; ventrals 199 ; subcaudals 92 . Uniform black above. I am now convinced that $N$. guentheri and $N$. goldii cannot be maintained as distinct species.

75. Dendraspis Jamesoni Traill.

$H a b$. Niger to Angola; Central Africa.

76. Bitis gabonica D. \& B.

$H a b$. Liberia to Damaraland; Zanzibar; Mozambique.

77. Bitis nasicornis Shaw.

$\mathrm{Hab}$. Liberia to Gaboon. 
78. AtHeris ChLOREChis Schleg.

$H a b$. Liberia to Gaboon.

79. Atheris squamiger Hallow.

$H a b$. Camaroons to Angola.

80. Atractaspis corpulenta Hallow.

$H a b$. Liberia to Gaboon.

81. Atractaspis boulengeri Mocq.

Atractaspis boulengeri, Mocq. Bull. Soc. Philom. (8) ix. 1897, p. 16.

$H a b$. Lambarene, Ogowe.

\section{EXPLANATION OF THE PLATES. \\ Plate XXVII.}

Fig. 1. Bufo latifrons, p. 435.

2. Arthroleptis inguinalis, p. 442 , two specimens.

3. Dilobates platycephalus, p. 444.

4. Rappia platyceps, p. 444.

\section{Plate XXVIII.}

Fig. 1. Scotobleps gabonicus, p. 439.

1 a. " " , Side view of head.

1 b. " " " Open mouth.

2. Phrynobatruchus auritus, p. 440.

3. . " latirostris, p. 440.

Plate XXIX.

Gampsosteonyx batesi, p. 442.

a. Upper view.

b. Side view of head.

c. Open mouth. d. Side view of 4 th toe, enlarged.

$e$. Lower view of 4 th toe, enlarged.

$f$. Distal phalanges.

\section{Plate XXX.}

Trichobatrachus robustus, p. 443.

a. Female, upper view.

b. Side riew of head. c. Open mouth.

d. Inner side of first finger of breeding male, enlarged.

\section{Plate XXXI.}

Fig. 1. Poromera fordi, female, p. 449.
$1 a$.
$\begin{array}{llll}1 \text { b. } & \text { lc. } \quad " \quad, \quad, \quad \text { Lower view of head }\end{array}$
Side view of head, $\times 2$.
]d. " " " male. Anal region, $\times 2$.
2. Mabuia batesi, p. 449.

\section{Plate XXXiI.}

Boulengerina annulata, p. 455, with upper and lower views of head. 

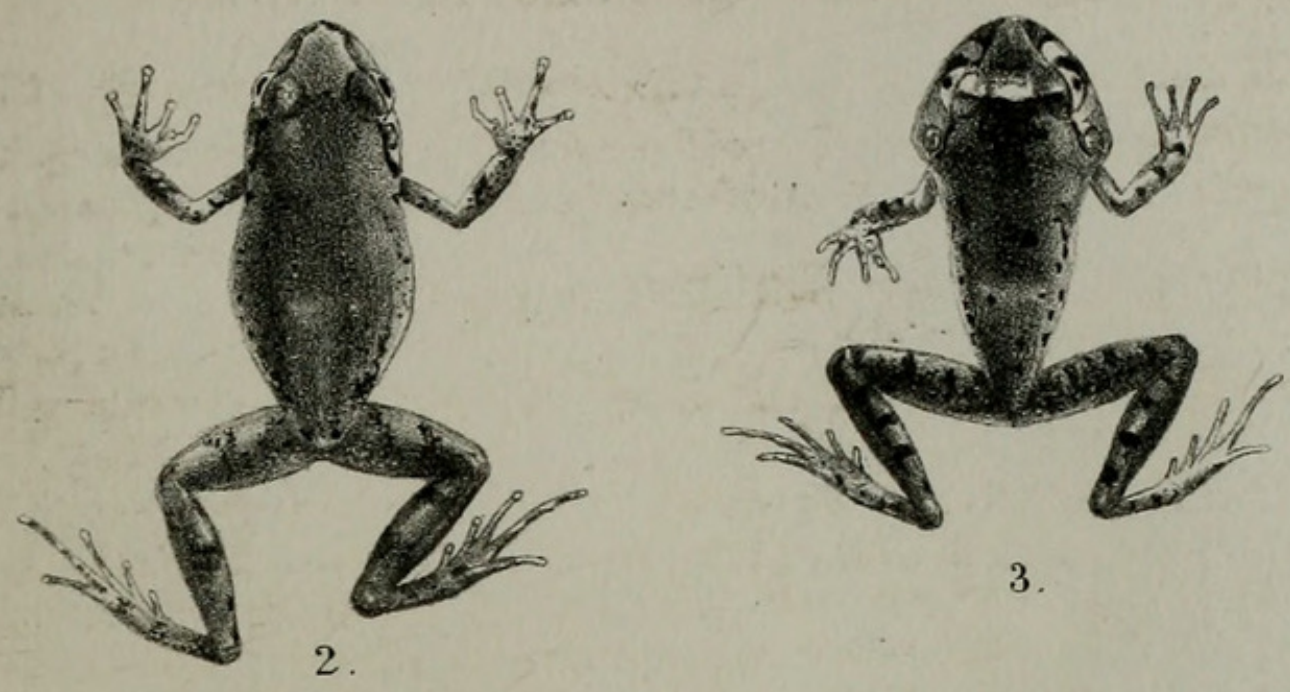

3.
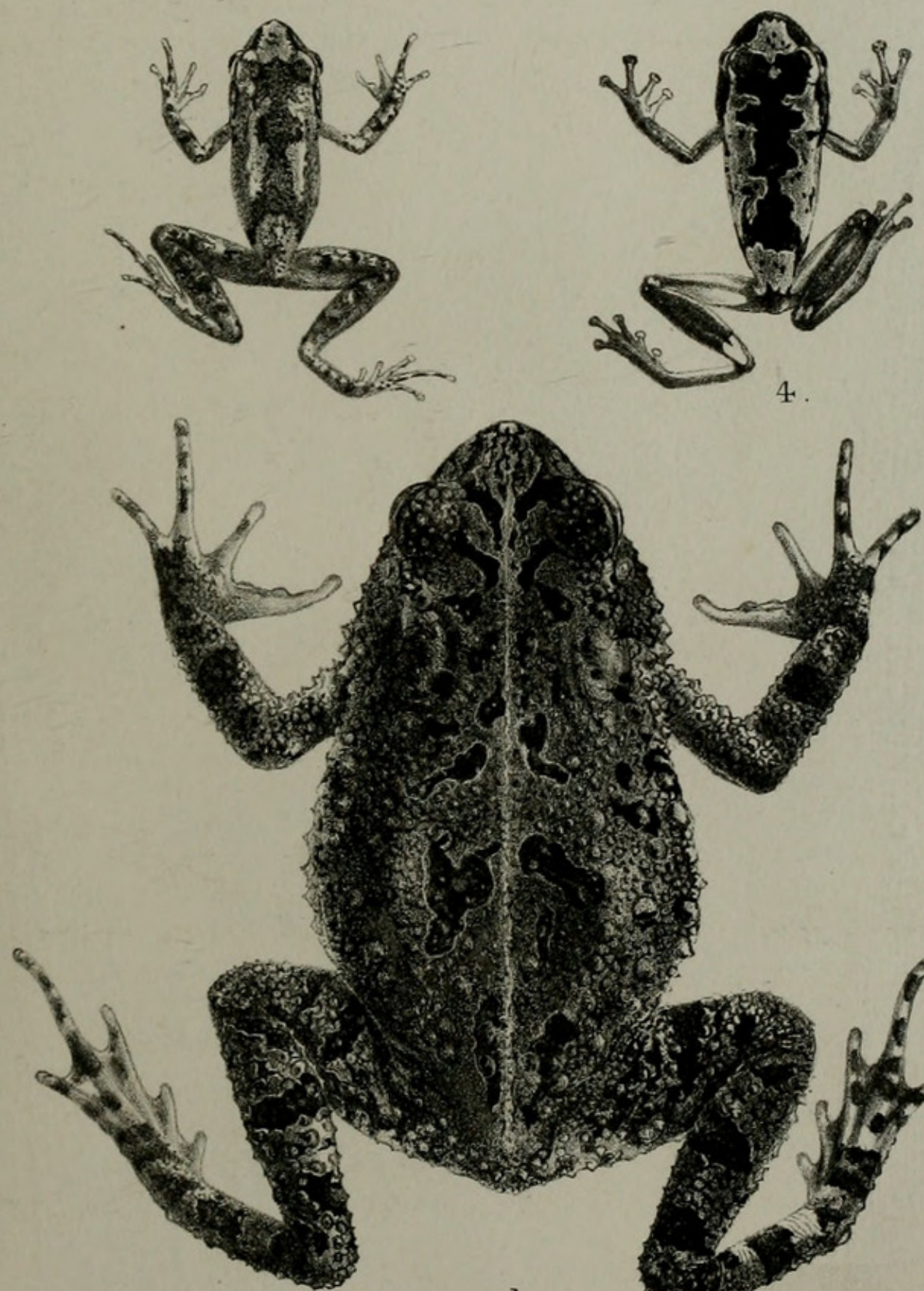

P.J.Smit del et lith.
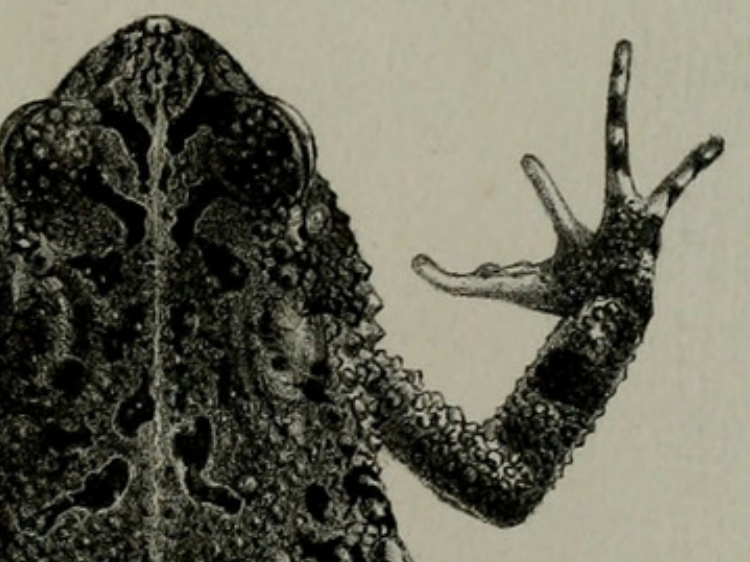

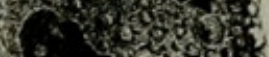
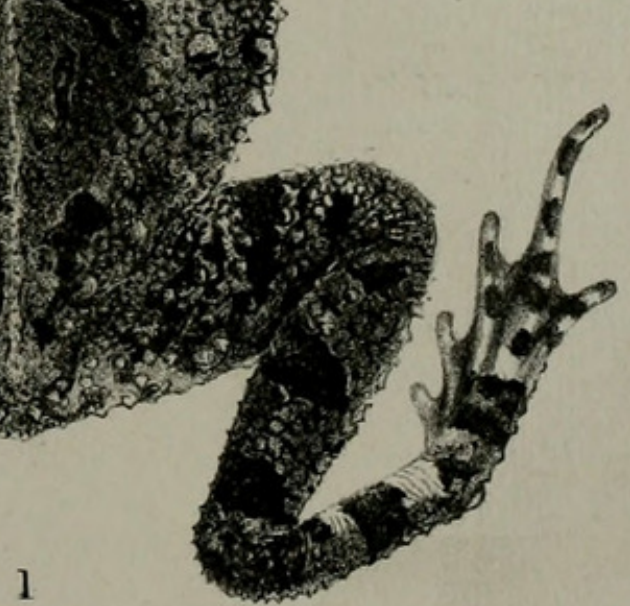

Mintern Bros imp

1.BUFO LATIFRONS. 2.ARTHROLEPTIS INGUINALIS 3.DILOBATES PLATYCEPHAL,US. 4RAPPIA PLATYCEPS. 


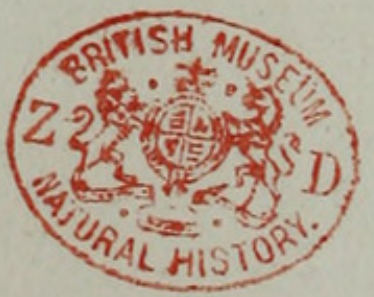



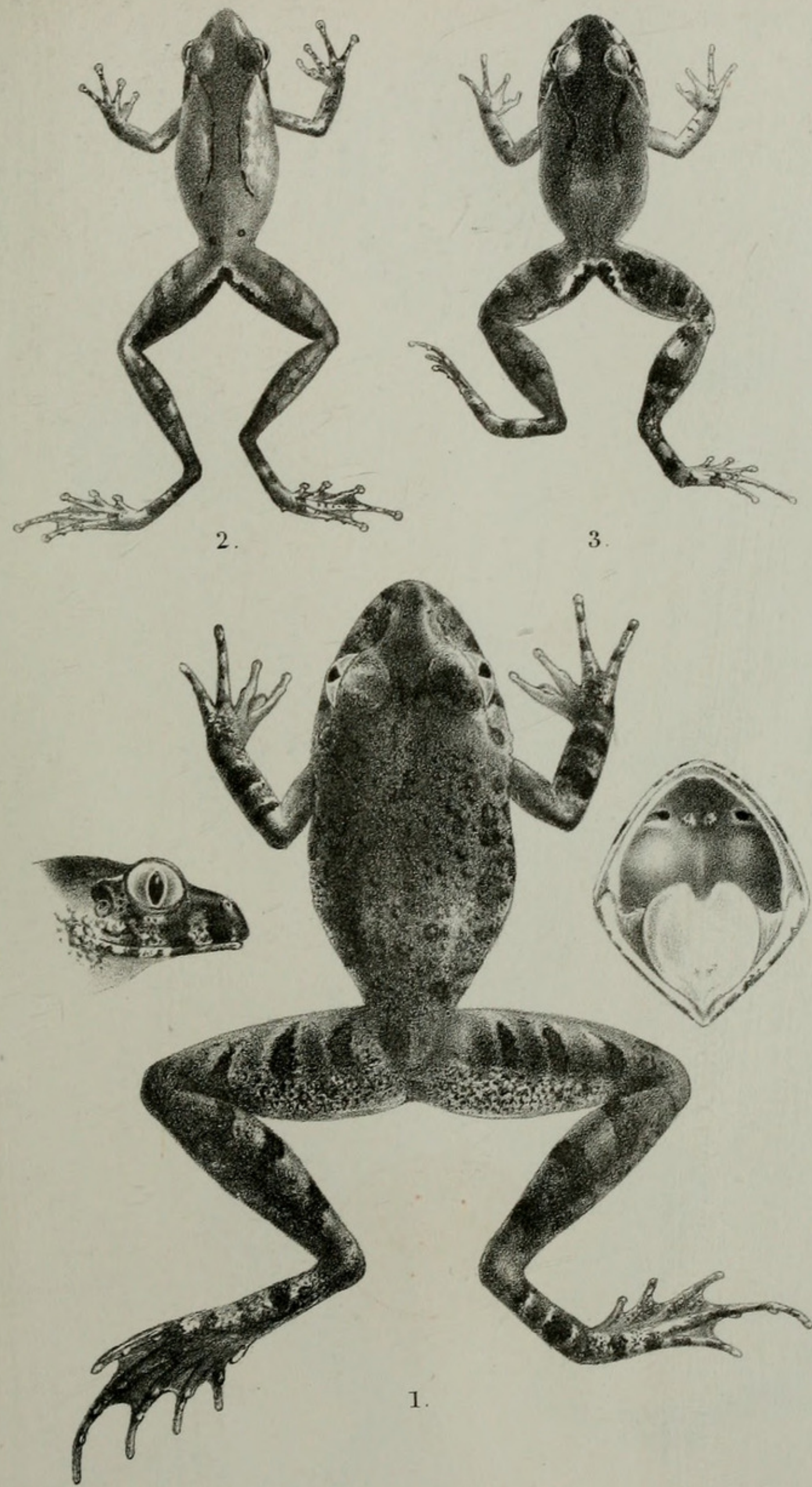

P.J. Smit del et lith. 
(2) 
P.Z.S 1900. PI.XXIX.
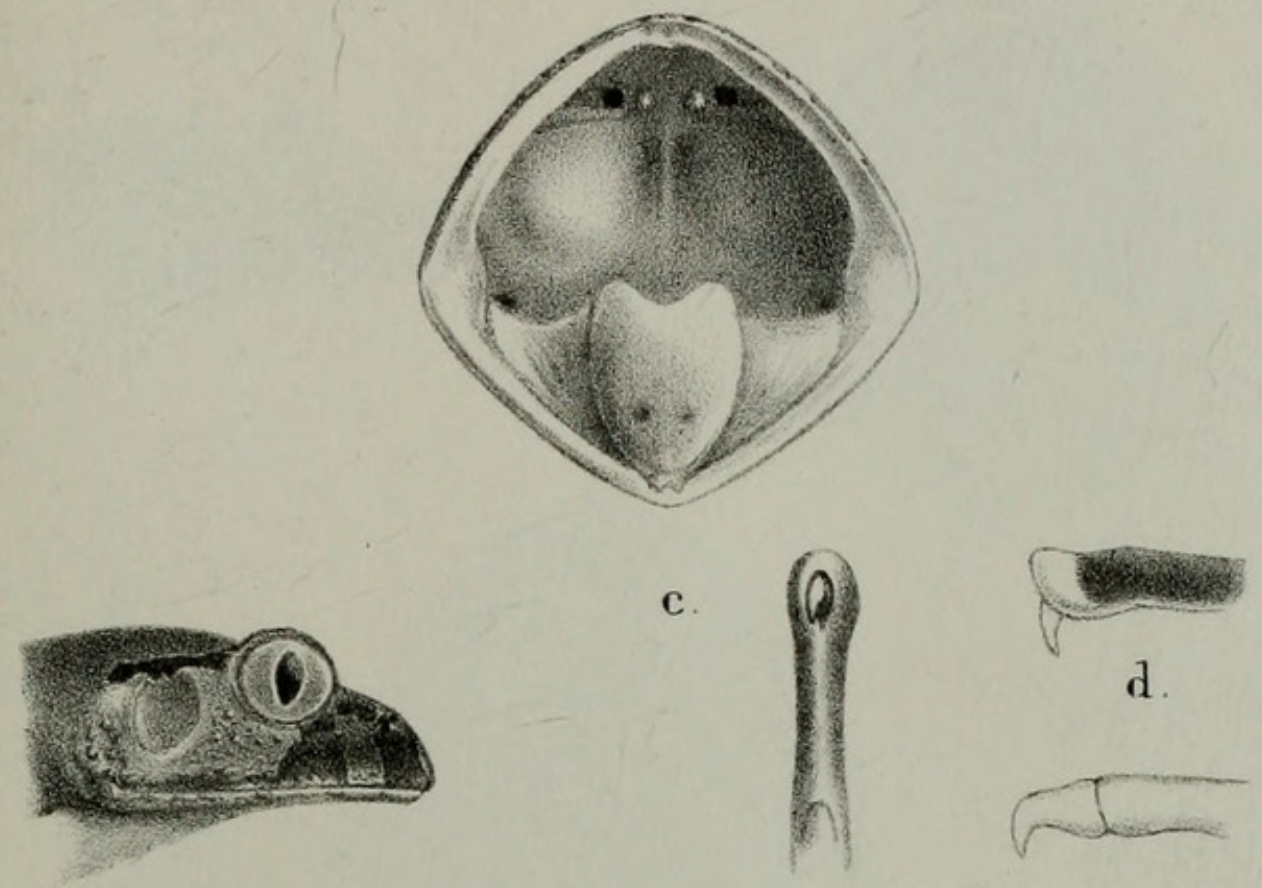

b

e.

f.

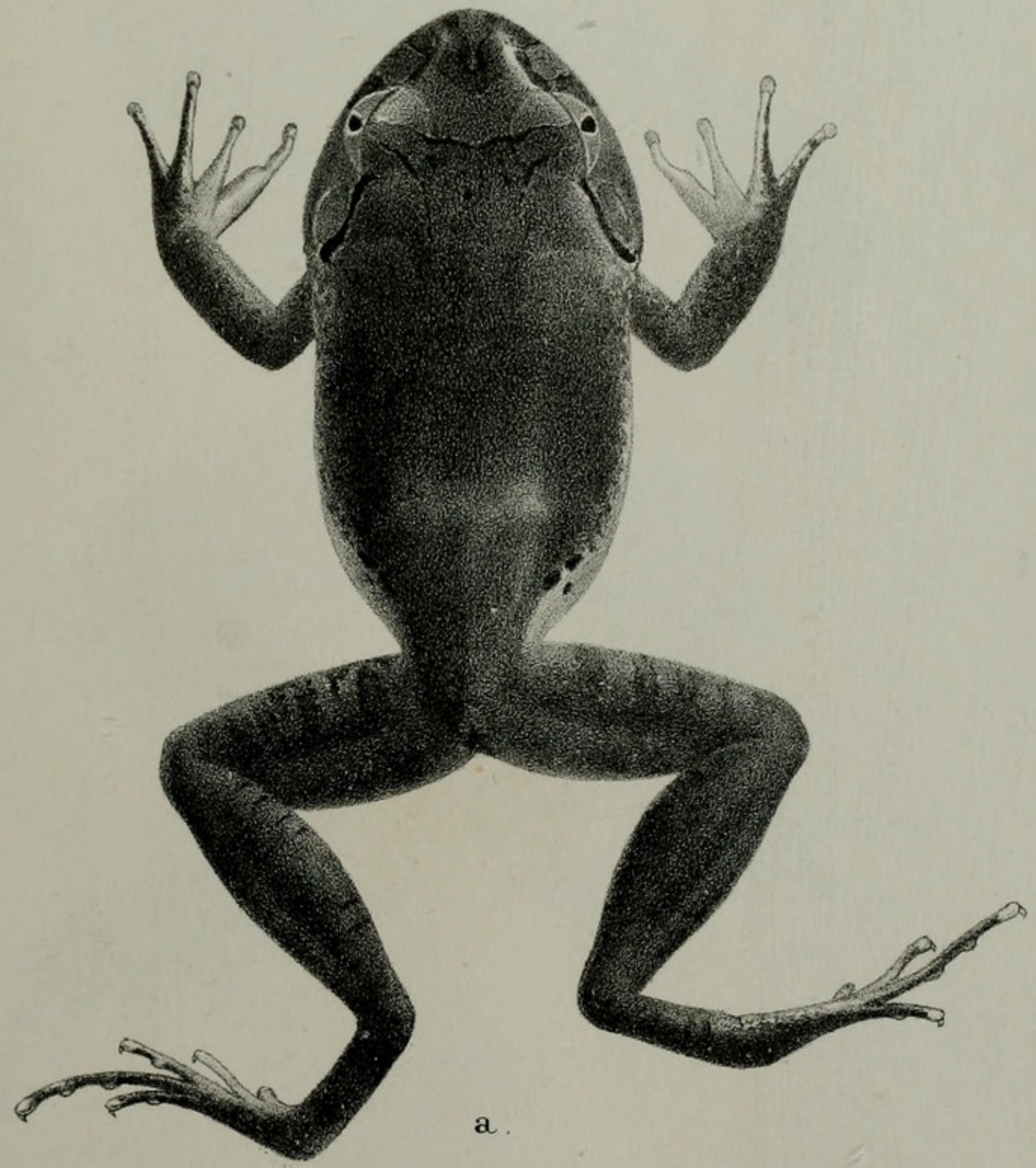

P. J.Smit del et lith Mintern Bros.imp. 




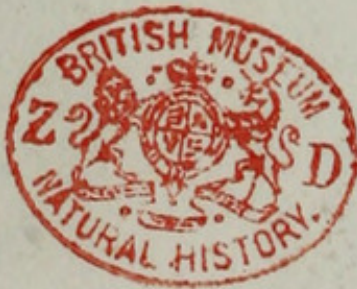


P.Z.S.1900.PI.XXXI

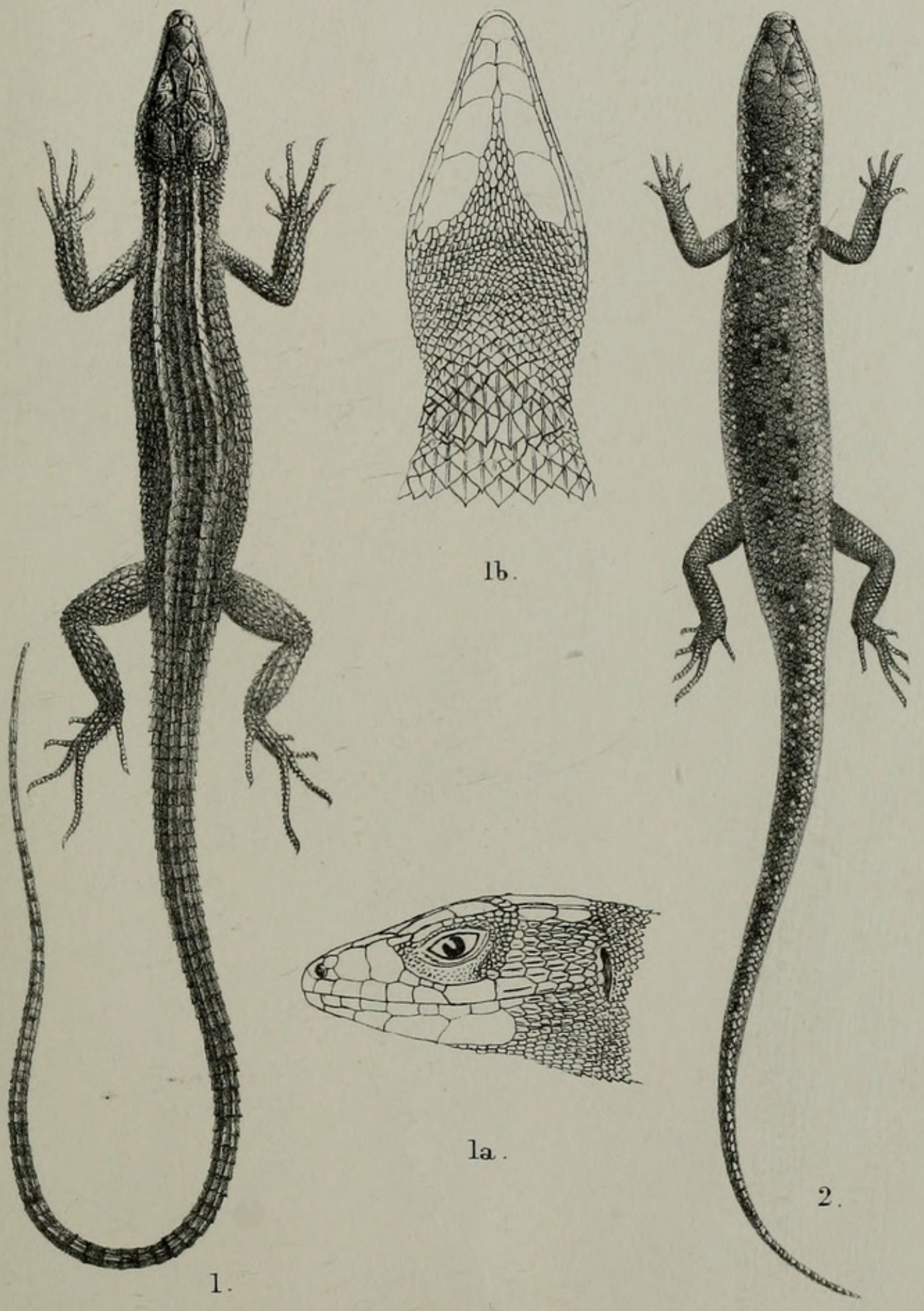

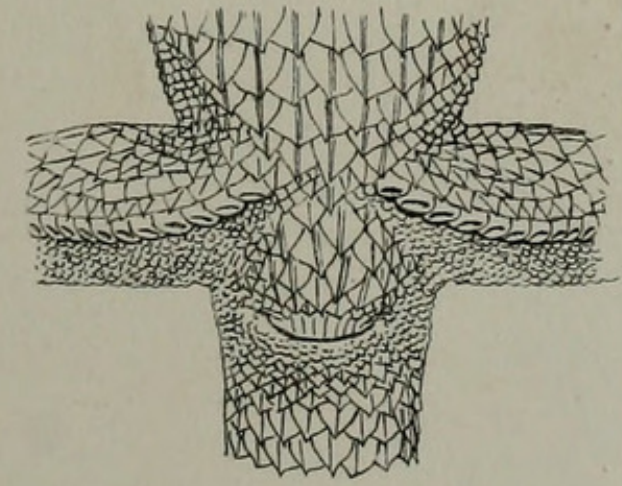

1 c.

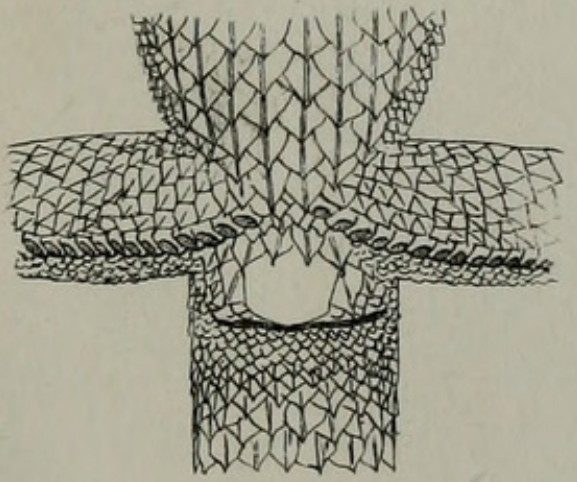

$1 d$.

P.J. Smit del.et lith.

Mintern Bros imp

1.POROMERA FORDII. 2.MABUIA BATESII. 


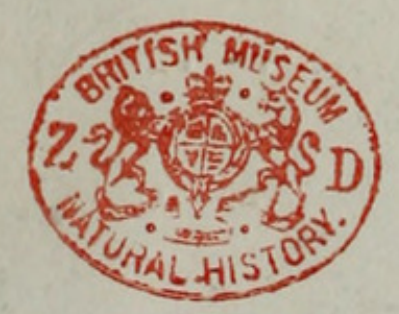




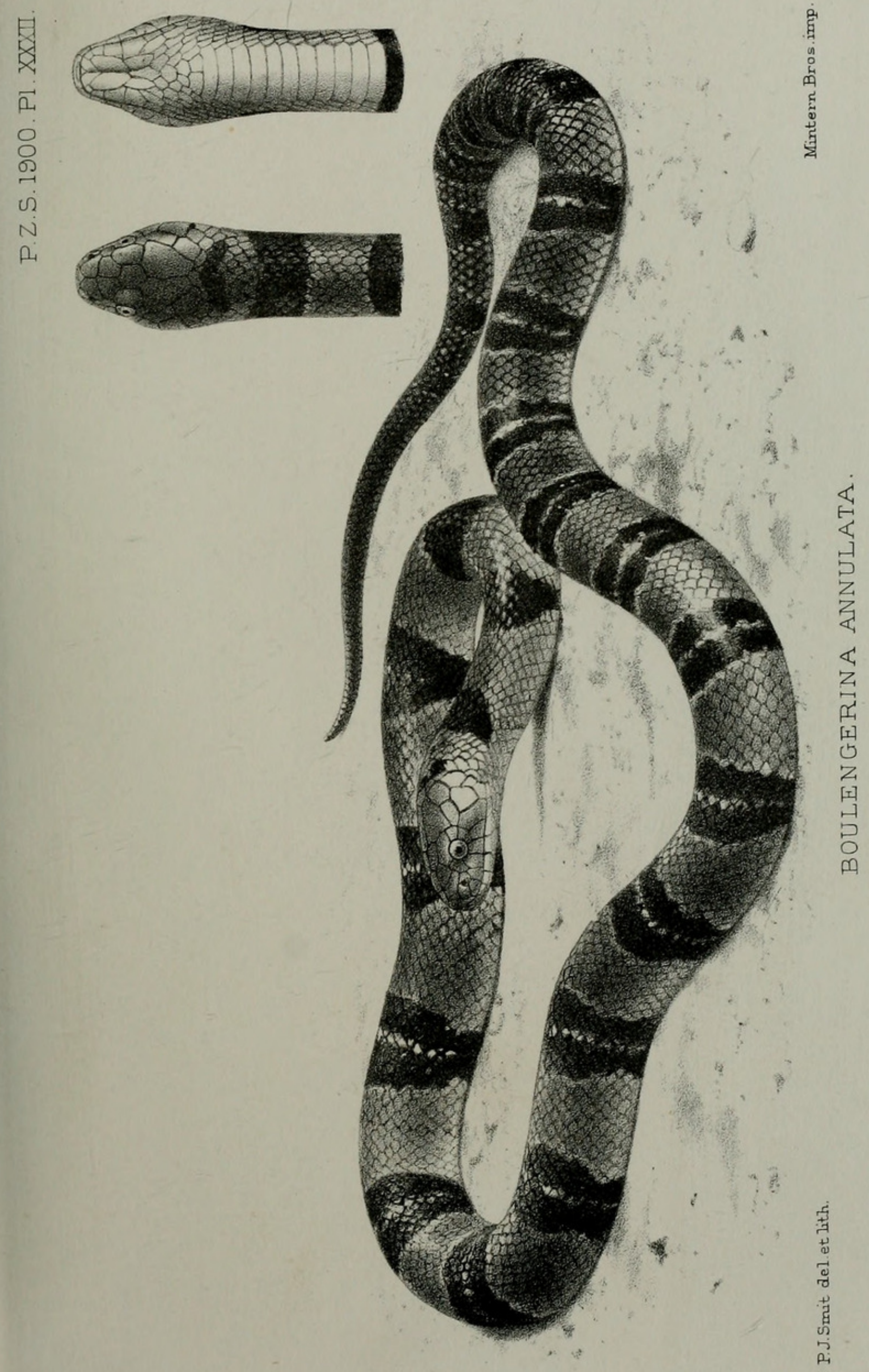


YRAL HIST 


\section{On the Birds of Hainan. By W. R. Ogilvie Grant.}

[Received March 4, 1900.]

\section{(Plates XXXIII. \& XXXIV.)}

The present paper, which gives a complete list of all the species of Birds known to occur in the island of Hainan, is based on the collection made by the late Mr. John Whitehead in the so-called 'Five-Finger Mountains' (Ngau-tchi-lea) in the interior. During this expedition he unfortunately fell a victim to the terrible forestfever, for which, it appears, the island is; at certain seasons, notorious.

I had arranged with $\mathrm{Mr}$. Whitehead that he should again proceed to the Philippines and complete his work there by investigating the fauna of the highlands of Mindanao and other islands forming the southern part of the archipelago, which he had not been able to visit during his previous expedition. It was further agreed that he should, if possible, explore the highlands of Formosa and Hainan.

On the 10th February 1899 he arrived at Manila, but after remaining there two weeks, during which time fighting between the Americans and Philipinos (Tagalos) continued daily, he was reluctantly obliged to give up all idea of collecting in the Philippines, and, returning to Hong-Kong, made his way to Hainan.

While in Manila he engaged the services of four Philipinos, including two of his most valued collectors who had accompanied him during his former expedition in the Philippines. Through the kindness of the late Mr. Whitehead's relations, I have been permitted to make use of his diary giving an account of his journey in Hainan; and I feel sure that the following extracts, melancholy though they be, will prove to be of interest as the last record of how this brave man and unrivalled field-naturalist lost his life in the cause of science ${ }^{1}$.

\section{DIARY.}

March 5th. Leave Hong-Kong for Hainan. Voyage to Hoihow. Stranded in the 'Hatin' for four days on a sandbank; afraid of losing our baggage; an anxious time. Get taken off the steamer by the 'Hoihow.' Experience difficulties in reaching the shore at low water. Mud-flats covered with flocks of Waders: Dunlins, Greenshanks, Stilts, Golden Plover, Redskanks, Curlews, and Sandplovers; also white-necked Crows.

On arriving in the town visit the Consul, and meet with great kindness from Mr. Jüdell, who puts me up. Baggage comes off in boats and arrives at daylight the next day.

1 An account of the late Mr. John Whitehead's scientific career will be found in 'Country Life,' vol. vii. no. 159, pp. 72, 73, 20th January, 1900. 
10th. Consulted the American missionaries, who are inclined to throw cold water on my visit to Nodia, their place inland, and can give no information! Determine not to ask their assistance any more. The Portuguese Padre Baptista promises to help me, and I hope to start in a few days. Mr. Jüdell rides with me to Kiungchu, a walled city, with narrow streets, stinks, darkness and crowds of people, a terrible-looking place-my first visit to a Chinese town. Pass many lepers on the road begging, minus fingers and toes and at times feet and hands-an awful sight!

13th. Left Hoinow for Pak-siang, which is the riverside port of Kiung-chu. I left Hoihow at 1.30, and arrived at the Padre Baptista's house in about an hour, and subsequently we went to meet the boat which, with men and baggage, left Hoihow this morning at 10 A.M. The Chinamen had filled up the boat with rice and flour for their own food, so consequently we had to move some of it. The Chinese always do their best to score off the European, and as a rule succeed. One hour's walk over a narrow road paved with big stones brought us to Pak-siang. The river runs through a sandy barren country, almost treeless, and no good to the collector, so one must go on. The sides of the river, where they are high, are of red burnt clay of voleanic origin, underneath this clay is sand and here and there a stratum of sea-shells. The river is broad and very shallow, the boats requiring to be pulled along by the men for long distances.

We have passed a number of bamboo water-wheels for irrigating purposes, and where these occur the river is dammed with a bamboo fence. When this has been passed, navigation once more becomes easy.

We have seen numerous birds, Ospreys, Kites, Crows, Magpies, a Cormorant, a Grebe, numbers of Waders, more especially Greenshanks, Herons, and black Storks, as well as Kingfishers of two kinds. Our boat is a dirty barge and smells very strong, but one might be worse off.

The Chinese work naked and are without shame, the greatest savages I have met with.

15th. Still going up stream with a nice wind, and make good progress, though our mat sail is much destroyed.

16th. Still going up stream, but slowly. Arrive at Ting-au, a small walled Chinese town. We have got porters for Sieum-tinsan, where the Padre Baptista has a priest, and we remain for the night.

17th. Left this morning with twenty-eight porters; could not get off early as the Chinese talked so much, but at 9.30 A.M. they were on their way. The country is almost a sandy desert; there has been no rain for so long that the rice and potato crop will in all probability be a failure: all the trees have been cut down and burnt, and a more arid place it would be difficult to find. We stopped to-night at Teen-heng-si, in a most horrible squalid house with a foul open drain at the door; unfortunately we were too late to camp outside. 
18th. After passing a horrible night, we started off at daylight for a 30 -mile walk over the sandy arid country, a truly miserable spot. Camped at night by the side of a river at Nam-lu-as (I am fully determined, if possible, never to enter a Chinese house again), and passed a fairly good night.

19th. Walked twenty miles to-day and at 3 o'clock reached Leamui, another wretched place; in fact the whole country is horrible and almost entirely cleared of trees-the Chinese burning down the forest to keep back the Lois or aborigines. I am afraid there are no birds, but fleas and other insects are everywhere.

20th. Went a long walk over the mountains to see if we could find collecting ground, but the place is very bare. I saw a Peregrine and several other birds.

21st. Getting baggage into small packs. I find my Chinese carriers a very great nuisance. Visited the Mandarin, and hope to start to-morrow.

22nd. Again visited Mandarin. His rifles are clean outside, but the rifling is eaten away with rust! Saw two Loi with their hair done up in front in a knob, like the horn of a unicorn.

23rd. Went for a walk over the bare mountain-sides, but caught a few nice butterflies on some flowering-plants. Saw a small redcoloured deer, two Peregrines, and, in the evening, some Nightjars, which settled on the tops of rocks on the summit of the hill. Their note is a curious shrill chirp, which, like that of a ventriloquist, seems to come from the ground near one's feet. Francolins are very common here. The porters say they will start to-morrow.

24th. The porters did not turn up till nearly 10 A.M.; then, as usual, went after their sticks; subsequently we had to visit the Mandarin, so did not leave until 12.30. After walking over some twelve or fifteen miles of the usual barren country, we reached a Chinese village, where we put up in the Joss-house, which was clean and well away from the stinks of the crowd.

25th. Started for the mountains again to-day, arriving at 5 P.м. at a small village, where we camped for the night. Saw a few birds, a Henicurus in the river, and a number of Pericrocoti, also a few Palceornis javanicus. I see neither the white Crow nor the Magpie so far inland. Francolins are still abundant. We meet every day Chinese carrying bundles of skins of deer, monkeys, and pangolins, so I am sure we are not far from some large forests.

26 th. Our Chinese porters refuse to go any further to-day; they say they have no rice, but, the truth is, they are done up and want to rest. The Mandarin sent two soldiers with us, so that we should be looked after; they have proved most useful. Some Chinese wanted to prevent our going through their village yesterday : one of them was, I think, drunk and nearly had a row with us. The country is slightly less barren, but still a miserable place for collecting in. Rain all night. The hills have been so enveloped in clouds, that I have not yet been able to see the mountain-tops. I hope to reach our destination some time to-morrow.

27 th. Instead of reaching our destination to-day, the Chinese 
have taken us a day's, journey further away from the mountains, as they say there is no road this (the north) side, so we have had to tramp over bare hills in a broiling sun. My old trouble dysentery is a great worry to me. The Lois or Lü, as the Chinese call them, are, so far as the men go, nearly like the Chinese. The hair is at times a pigtail tied in a knob, but more often a knob of hair tied in front, which looks like a unicorn's horn. Their villages are small, the houses of grass and sloped like an arch, and they live on the ground. The women are quite distinct from the Chinese, wearing very short skirts of blue, or blue with a red-and-white pattern.

28th. Still on the march. Arrived at Lü village in the evening, but the men seemed so disagreeable, that we went about half a mile away and camped. They then followed to see all they could, and were amazed at our guns. Bought half a big pig for $\$ 1 \cdot 50$.

29th. Left early, as I wanted to camp near the mountain. Sent Andres and Juan off at 4 A.M. to look for a spot. Nearly had a row with our Chinese porters, but formed up in their rear so that they had to go on after using a good deal of bad language at us. Have struck a nice place for a camp, close to a fine rocky stream not far from the mountains. Hear lots of birds. Am very seedy with dysentery, Juan with fever. Busy building a house all day.

30th. Busy house-building. Caught some beautiful butterflies in the river. Saw a fine Kingfisher, I think Alcedo euryzona, also some monkeys.

31st. This being Good Friday, we have resolved not to begin collecting to-day-unlucky--but to finish off the house. It rained this morning and was very cold before daylight. A cloudy day, saw no butterflies. Begin collecting to-morrow.

APrIL 1st. At last we were able to go shooting. Andres brought in four birds. Hills very steep, sand and rocks; this is the reason why they are left alone by the natives. Sand-flies awful. Butterflies numerous in the river-bed. Saw a large Kingfisher and some squirrels.

Natives visit us daily : fowls 10 cts., ducks 25 cts., eggs $\frac{1}{2}$ ct.

2nd. Very seedy with dysentery. Juan shot a Silver Pheasant which may be new (see Gennceus whiteheadi, p. 503), and a fine Paradise Flycatcher. Heat and sand-flies awful.

3rd-19th. All ill with fever and dysentery.

19th-30th. The bird collection is going along slowly-my men being all ill one day or another, one or two have been ill every day with fever. I am perhaps in better health than I have been for some time. Lū women catching caterpillars for food. It rains heavily and thunders every afternoon, and our life here, owing to fever, is most miserable.

Mar 1st-6th. All my men ill with bad fever. The two Chinese and myself do not suffer much.

7th. I saw a Lū with some rat-traps identical with those made 
by the Kina Balu Dusans. Changed into my new house. Very fine for the last few days, no rain. Men (Philipinos) hopelessly ill, and have done nothing for a fortnight. Sent the Chinese soldier out to shoot for me; want to see if he is worth anything.

9th. Three of my Manila men left me to-day of their own accord. I trust they will reach Hoihow safely. It makes me very sad all this illness. I gave them the option of going, as I should be very sorry to be the cause of the death of any one of them.

10 th. To-day is very wet; the Manila men will have a sad time of it, I expect. My boy Juan is still with me, not because he cares about staying with me, but because he was too ill to start with the others. The Chinese soldier is doing my shooting and gets on very well.

11 th-16th. Am trying to work on with one boy, who is not much use at bird-skinning. The Lü are beginning to bring things, which is a good job, so perhaps I shall get on after all.

20th. Attacked again by fever-very seedy-useless. John Afar also.

21st-23rd. Nearly dead with fever-no food-no depression of temperature.

24th May. (Diary ends.)

The faithful Chinese servants carried Mr. Whitehead's body and all his belongings to Hoihow, and his remains were interred in the cemetery by the sea. The journey from the interior was accomplished in 19 days.

Through the kindness of the Consul, Mr. Butler O'Brien, Whitehead's zoological collections were carefully packed and shipped to England, arriving safely in due course. The collection of birds, numbering about 250 skins, all in the most perfect condition, includes many striking novelties, the most remarkable being a very peculiar Jay (Urocissa whiteheadi), a splendid Silver Pheasant (Gennceus whiteheadi), and an equally fine Night-Heron (Nycticorax magnifica). The two last-named species have been well figured by $\mathrm{Mr}$. H. Grönvold in the accompanying drawings.

That Mr. Whitehead should have succeeded, under the most adverse circumstances, in obtaining such splendid results in a comparatively short time, indicates that much still remains to be done in the highlands of the interior of Hainan, but, as his diary too clearly shows, the deadly climate of the forests will probably deter even the most hardy explorer from following in his footsteps.

[The species of which specimens were obtained in the FiveFinger Mountains are marked with an asterisk.]

1. Corvus levaillanti.

Corvus sinensis, Moore; Swinhoe, Ibis, 1870, p. 348, fig. 1.

Corone levaillanti (Lesson); Sharpe, Cat. B. Brit. Mus. iii. p. 39 (1877).

Proc. Zoor. Soc.-1900, No. XXXI. 
Corvus levaillanti, Lesson; Hartl. Abh. nat. Ver. Bremen, xii. pp. 299, 312 (1892).

Hainan birds of this species appear to belong to a slightly larger race.

Common about the towns of Hainan (Swinhoe).

\section{Corvus torquatus.}

Corvus torquatus, Less.; Swinhoe, Ibis, 1870, p. 350 ; Sharpe, Cat. B. Brit. Mus. iii. p. 21 (1877); Hartl. Abh. nat. Ver. Bremen, xii. pp. 299, 312 (1892).

Common in the plains of North and North-west Hainan (Swinhoe).

\section{Pida PICA.}

Pica media, Blyth; Swinhoe, Ibis, 1870, p. 350.

Pica pica (Linn.), Sharpe, Cat. B. Brit. Mus. iii. p. 62 (1877); Styan, Ibis, 1893, p. 431.

Pica caudata, Hartl. Abh. nat. Ver. Bremen, xii. pp. 299, 312 (1892), xiv. p. 366 (1898).

Abundant everywhere (Swinhoe).

4. UROCISSA ERYTHRORHYNCHA.

Urocissa erythrorhyncha (Gmel.); Sharpe, Cat. B. Brit. Mus. iii. p. 71 (1877); Hartl. Abh. nat. Ver. Bremen, xii. pp. 299, 312 (1892).

An example of this species was procured in North Hainan by Tetsu, the late Mr. Schmacker's Japanese collector, and identified by Dr. Hartlaub.

\section{5. *UROCISSA WHITEHEAdi.}

Urocissa whiteheadi, Grant, Bull. B. O. C. vol. x. p. xviii (1899).

This remarkable species may be characterized as follows:Sexes similar one to another in plumage. Head, back, fore-neck, and chest dark earthy brown, darkest on the ear-coverts, and shading into grey on the sides and flanks, and into yellowish buff on the middle of the breast, belly, and under tail-coverts; feathers of the crown rounded at the extremity and edged with whitish brown; rump greyish brown; upper tail-coverts black, tipped with white; wings black, except the lesser and median wingcoverts, which are white save at the base; tips of the primaryquills, margins of the terminal half of the outer webs of the secondaries, and the tips of the greater wing-coverts pure white; middle tail-feathers grey, widely tipped with white and with a subterminal black band; the outer feathers similarly marked, but with the white tips increasing in size and shaded with yellow; axillaries and under wing-coverts clear yellowish white. "Iris straw-colour; bill red, shading into brownish yellow at the base; 
feet dark brown." $-J . W$. Total length about 18 inches ; culmen 1.9 ; wing $8 \cdot 2$; tail $9 \cdot 4$; tarsus 1.95 .

Mr. Whitehead was fortunate in obtaining a nest and eggs of this remarkable new species. The nest, a very slightly concave platform, is semitransparent, and formed of dry stems of creepers and roots, firmly interwoven.

The eggs, six in number, have the ground-colour pale greenish blue, sparingly spotted and dotted with light brown. The average measurements are $1.4 \times 1$ inch.

\section{6. *Dendrocitta sinensis.}

Dendrocitta sinensis (Lath.); Swinhoe, Ibis, 1870, p. 351; Sharpe, Cat. B. Brit. Mus. iii. p. 81 (1877); Styan, Ibis, 1893, p. 431 ; Hartl. Abh. nat. Ver. Bremen, xiv. p. 366 (1898).

"Iris dull lake; bill black; feet dull brownish black."-J. W.

Not uncommon among the fine woods of Shuy-wei-sze, Central Hainan (Swinhoe).

Mountains of South-west Hainan (Styan).

7. *Sturnia sinensis.

Temenuchus sinensis (Gmel.); Swinhoe, Ibis, 1870, p. 352.

Sturnia sinensis, Sharpe, Cat. B. Brit. Mus. xiii. p. 68 (1890); Hartl. Abh. nat. Ver. Brem. xii. pp. 219, 314 (1892); Styan, Ibis, 1893, p. 431 ; Hartl. Abh. nat. Ver. Bremen, xiv. p. 365 (1898).

ㅇ. "Iris greyish white; bill whitish blue, cobalt at base; feet whitish brown."-J. $W$.

Common on the coast of Hainan in March (Swinhoe).

Mountains of South-west Hainan (Styan).

\section{8. *Acridotheres cristatellús.}

Acridotheres philippensis, Bonap.; Swinhoe, Ibis, 1870, p. 352.

Acridotheres cristatellus (Gmel.) ; Sharpe, Cat. B. Brit. Mus. xiii. p. $92(1890)$.

o. "Iris orange-yellow; bill whitish green, base of lower mandible pinkish; feet yellowish brown."- $J . W$.

Abundant about all towns and villages (Swinhoe).

9. Spodiopsar cineraceus.

Sturnus cineraceus, Temm. ; Swinhoe, Ibis, 1870, p. 352.

Spodiopsar cineraceus, Sharpe, Cat. B. Brit. Mus. xiii. pp. 41, $665(1890)$.

Poliopsar cineraceus, Hartl. Abh. nat. Ver. Bremen, xii. pp. 299, 314 (1892).

Met with during February (Swinhoe).

10. Spodiopsar sericeus.

Spodiopsar sericeus (Gmel.); Sharpe, Cat. B. Brit. Mus. xiii. pp. 44,665 (1890). 
Poliopsar sericeus (Gmel.); Hartl. Abh. nat. Ver. Bremen, xii. pp. 299, 314 (1892).

Adult and young were obtained by Mr. Schmacker's collector, Tetsu, in North Hainan (Hartlaub).

\section{1. "Temnurus niger.}

Crypsirhina nigra, Styan, Bull. B. O. C. vol. i. p. vi (1892); id. Ibis, 1893, p. 55.

Temnurus niger, Sharpe, Bull. B. O. C. vol. i. p. xix (1892); Styan, Ibis, 1893, p. 431.

Temnurus schmackeri, Styan, Ibis, 1893, p. 426 (descript. null.).

It is doubtful whether this species is really distinct from the type of Temnurus truncatus, which is said to have come from Cochin China and is preserved in the Paris Museum.

Obtained by Tetsu at Liuwowan, on the north slopes of the mountains of South-west Hainan.

\section{2. *Mainatus intermedius.}

Eulabes hainanus, Swinhoe, Ibis, 1870, p. 352.

Mainatus intermedius (A. Hay); Sharpe, Cat. B. Brit. Mus. xiii. p. $104(1890)$.

"Iris brown ; bill orange-red, tip and lappet orange-yellow ; feet yellow."-J. $W$.

Though Swinhoe saw these Grackles in the cages in the towns of Hainan, he never met with them in a wild state.

Several birds were obtained by the late $\mathrm{Mr}$. Whitehead in the Five-Finger Mountains.

\section{3. * Chaptia menea.}

Chaptia anea (Vieill.); Sharpe, Cat. B. Brit. Mus. iii. p. 243, (1877).

o. " Iris dark bazel; bill and feet black." $-J . W$.

This is the first time this species has been recorded from Hainan.

\section{4. *Buchanga LeUCOGENYS.}

Buchanga leucogenys, Wald.; Swinhoe, Ibis, 1870 , p. 245 ; Sharpe, Cat. B. Brit. Mus. iii. p. 251 (1877); Styan, Ibis, 1893, p. 429 .

o. "Iris lake; bill and feet black."-J. W.

Not rare in the woods of Central Hainan (Swinhoe).

Mountains of South-west Hainan (Styan).

\section{Buohanga atra.}

Dicrurus macrocercus, Vieill.; Swinhoe, Ibis, 1870, p. 244.

Buchanga atra (Hermann); Sharpe, Cat. B. Brit. Mus. iii. p. 246 (1877); Hartl. Abh. nat. Ver. Bremen, xii. pp. 299, 313 (1892) ; Styan, Ibis, 1893 , p. 429 ; Hartl. Abh. nat. Ver. Bremen, xiv. p. 357 (1898).

Found in all eultivated parts of Hainan (Swinhoe). 


\section{Buchanga cineracea.}

Buchanga mouhoti, Wald.; Swinhoe, Ibis, 1870, p. 245.

Buchanga innexa, Swinhoe, Ibis, 1870, p. 246.

Buchanga cineracea (Horsf.); Sharpe, Cat. B. Brit. Mus. iii. p. 250 (1877); Hartl. Abh. nat. Ver. Bremen, xii. pp. 299, 313 (1892).

No reference is made in the 'Catalogue of Birds' to Buchanga innexa Swinhoe. The British Museum Collection now contains the female type of this species, which appears to be an immature example of $B$. cineracea ; the male type has apparently disappeared.

North-west and Central Hainan (Swinhoe).

\section{7. *Dissemurus paradiseus.}

Dissemurus paradiseus (Linn.) ; Sharpe, Cat. B. Brit. Mus. iii. p. 258 (1877).

In none of the specimens are the feathers on the back of the neck much elongated.

\begin{tabular}{|c|c|c|c|c|c|}
\hline $\begin{array}{l}\text { Crest. } \\
\text { in. } \\
1 \cdot 8\end{array}$ & $\begin{array}{l}\text { Culmen. } \\
\text { in. } \\
1.5\end{array}$ & $\begin{array}{l}\text { Wing. } \\
\text { in. } \\
6 \cdot 3\end{array}$ & $\begin{array}{l}\text { Tail. } \\
\text { in. } \\
6 \cdot 9\end{array}$ & $\begin{array}{l}\text { Tail to tip } \\
\text { of racket. } \\
\text { in. } \\
16.5\end{array}$ & $\begin{array}{c}\text { Tarsus. } \\
\text { in. } \\
1 \cdot 1\end{array}$ \\
\hline $2 \cdot 0$ & 1.5 & $6 \cdot 5$ & $6 \cdot 3$ & $14 \cdot 1$ & $\begin{array}{l}1 \cdot 1 \\
1 \cdot 2\end{array}$ \\
\hline $2 \cdot 2$ & $1 \cdot 4$ & $6 \cdot 3$ & $6 \cdot 1$ & $14 \cdot 4$ & $1 \cdot 1$ \\
\hline $1 \cdot 85$ & $1 \cdot 4$ & $6 \cdot 1$ & $6 \cdot 8$ & $14 \cdot 4$ & $1 \cdot 1$ \\
\hline
\end{tabular}

This Drongo is recorded for the first time from Hainan.

\section{8. * OrIOLUS DIFFUSUS.}

Oriolus chinensis, Swinhoe (nec Linn.), Ibis, 1870, p. 342.

Oriolus diffusus, Sharpe, Cat. B. Brit. Mus. iii. p. 197 (1877); Styan, Ibis, 1893 , p. 429 ; Hartl. Abh. nat. Ver. Bremen, xiv. p. 356 (1898).

Northern slopes of the mountains of South-west Hainan (Styan). North-central Hainan (Hartlaub).

\section{Oriolus nigellicaudus.}

Psaropholus ardens, var. nigellicauda, Swinhoe, Ibis, 1870 , p. 342. Psaropholus nigellicauda, Hartl. Abh. nat. Ver. Bremen, xii. pp. 299, 313 (1892).

Oriolus nigellicaudus, Sharpe, Cat. B. Brit. Mus. iii. p. 221 (1877). Tai-ping-sze, Central Hainan, and Yulinkan, South Hainan (Swinhoe).

North Hainan (Hartlaub).

20. Munia topela.

Munia topela, Swinhoe, Ibis, 1870, p. 354; Sharpe, Cat. B. Brit. Mus. xiii. p. 351 (1890); Hartl. Abh. nat. Ver. Bremen, xii. pp. 299, 315 (1892); Styan, Ibis, 1893, p. 431; Hartl. Abh. nat. Ver. Bremen, xiv. p. 362 (1898).

Common in Hainan (Swinhoe).

Hoihow (Hartlaub).

Northern slope of the mountains of South-west Hainan (Styan). 


\section{1. *UROLONCHA SQUAMICOLLIS.}

Munia acuticauda, Swinhoe (nec Hodgs.), Ibis, 1870, p. 354.

Uroloncha squamicollis, Sharpe, Cat. B. Brit. Mus. xiii. p. 359 (1890).

. "Iris light hazel ; upper mandible black, lower whitish blue; feet dull black." - J. W.

Common (Swinhoe).

\section{Passer montanus.}

Passer montanus (Linn.); Swinhoe, Ibis, 1870, p. 354 ; Sharpe, Cat. B. Brit. Mus. xii. p. 301 (1888).

This is the domestic Sparrow of Hainan (Swinhoe).

23. Emberiza fucata.

Emberiza fucata, Pall.; Swinhoe, Ibis, 1870 , p. 354; Sharpe, Cat. B. Brit. Mus. xii. p. 493 (1888); Styan, Ibis, 1893, p. 431.

Lingmun, Central Hainan, 23rd February (Swinhoe).

Northern slopes of the mountains of South-west Hainan (Styan).

\section{Emberiza spodocephala.}

Emberiza spodocephala, Pall.; Swinhoe, Ibis, 1870, p. 354 ; Sharpe, Cat. B. Brit. Mus. xii. p. 522 (1888).

Common about gardens in February (Swinhoe).

\section{5. *EMBeriza AUREOLA.}

Emberiza aureola, Pall.; Swinhoe, Ibis, 1870 , p. 354 ; Sharpe, Cat. B. Brit. Mus. xii. p. 509 (1888); Hartl. Abh. nat. Ver. Bremen, xii. pp. 299, 315 (1892).

"Iris dark brown; bill whitish brown on the culmen; feet light pinkish brown." $-J . W$.

Haosuy, West Hainan, 29th March (Swinhoe).

North Hainan, 19th March (Hartlaub).

The late Mr. Whitehead obtained an adult male on the FiveFinger Mountains, 8th May.

\section{Alauda gulgula.}

Alauda coelivox, Swinhoe, Ibis, 1870, p. 354.

Alauda sala, Swinhoe, Ibis, 1870 , p. 354.

Alauda gulgula, var. sala, Sharpe, Cat. B. Brit. Mus. xiii. p. 575 (1890).

Alauda wattersi, Swinhoe; Styan, Ibis, 1893, p. 431.

The varieties Alauda coelivox and A. sala are both found in Hainan.

The former is common in all cultivated parts of Hainan and even met with at Lingmun, Central Hainan (Swinhoe).

The latter was obtained at Hoitow, West Hainan (Swinhoe).

Northern slopes of the mountains of South-west Hainan (Styan). 


\section{Motacilla ocularis.}

Motacilla ocularis, Swinhoe, Ibis, 1870, p. 346 ; Sharpe, Cat. B. Brit. Mus. x. p. 471, pl. iv. figs. 5, 6 (1885).

Tolerably common (Swinhoe).

The three specimens obtained by Swinhoe in Hainan are no longer to be found, they are not in the Seebohm Collection nor are they mentioned in the Catalogue of the Tristram Collection.

28. Motacilla leucopsis.

Motacilla francisi, Swinhoe, Ibis, 1870, p. 345.

Motacilla leucopsis, Gould; Sharpe, Cat. B. Brit. Mus. x. p. 482 (1885) ; Styan, Ibis, 1893 , p. 428 ; Hartl. Abh. nat. Ver. Bremen, xiv. p. 354 (1898).

Two specimens were obtained by Swinhøe. It was recorded from Hoihow, North Hainan, by Hartlaub, and from South-western Hainan by Styan.

29. Motacilla melanope.

Calobates boarula, Linn.; Swinhoe, Ibis, 1870, p. 346.

Motacilla melanope, Pall.; Sharpe, Cat. B. Brit. Mus. x. p. 497 (1885) ; Styan, Ibis, 1893, p. 428 ; Hartl. Abh. nat. Ver. Bremen, xiv. p. 354 (1898).

Not common (Swinhoe).

South-west Hainan (Styan).

Hoihow, North Hainan (Hartlaub).

30. Motacilla taivana.

Budytes taivanus, Swinhoe, Ibis, 1870, p. 346.

Motacilla taivana, Sharpe, Cat. B. Brit. Mus. x. p. 514 (1885).

The bird collected by Swinhoe is now in the Liverpool Museum.

31. Motacilla borealis.

Budytes cinereocapillus, Swinhoe (nec Savi), Ibis, 1870, p. 346.

Motacilla borealis, Sundev. ; Sharpe, Cat. B. Brit. Mus. x. p. 522, pl. vii. figs. 1-3 (1885).

The example collected by Swinhoe on West Island, South Hainan, is now in the British Museum Collection.

32. Anthus maculatus.

Pipastes agilis (Sykes); Swinhoe, Ibis, 1870, p. 347.

Anthus maculatus, Hodgs.; Sharpe, Cat. B. Brit. Mus. x. p. 547 (1885); Hartl. Abh. nat. Ver. Bremen, xii. pp. 299, 311 (1892).

The British Museum Collection possesses a young bird obtained by Swinhoe, who says that the species was to be found at most of the places he visited.

North Hainan (Hartlaub).

33. ANthus RichaRdi.

Corydalla richardi (Vieill.); Swinhoe, Ibis, 1870, p. 347. 
Anthus richardi, Sharpe, Cat. B. Brit. Mus. x. p. 564 (1885); Hartl. Abh. nat. Ver. Bremen, xii. pp. 299, 311 (1892); Styan, Ibis, 1893 , p. 428 ; Hartl. Abh. nat. Ver. Bremen, xiv. p. 354 (1898).

Two specimens collected by Swinhoe are now in the British Museum Collection.

Common (Swinhoe).

Hoihow, North Hainan (Hartlaub).

South-west Hainan (Styan).

\section{Anthus cervinus.}

Anthus cervinus (Pall.); Swinhoe, Ibis, 1870, p. 347; Sharpe, Cat. B. Brit. Mus. x. p. 585 (1885); Styan, Ibis, 1893, p. 428; Hartl. A bh. nat. Ver. Bremen, xiv. p. 354 (1898).

Often met with in small parties (Swinhoe).

Hoihow, North Hainan (Hartlaub).

South-west Hainan (Styan).

35. Anthus rosaceus.

Anthus rosaceus, Hodgs.; Sharpe, Cat. B. Brit. Mus. x. p. 589 (1885); Hartl. Abh. nat. Ver. Bremen, xiv. p. 354 (1898).

Dr. Hartlaub records two males from Hoihow, North Hainan.

36. * Еthopyga CHRISTIN

Athopyga christince, Swinhoe, Ann. Mag. N. H. (4) iv. p. 436 (1869) ; id. Ibis, 1870 , p. 236 ; Walden, Ibis, 1870 , p. 36, pl. i. fig. 1; Gadow, Cat. B. Brit. Mus. ix. p. 30 (1884); Styan, Ibis, 1893 , p. 430 ; Hartl. Abh. nat. Ver. Bremen, xiv. p. 361 (1898).

Urodrepanis christince (Swinh.); Shelley, Monogr. Nect. i. p. 79, pl. 26.

" $\sigma$. Eye and bill black; feet dark brown."- $J . W$.

Shuy-wei-sze and Lingmun, Central Hainan (Swinhoe).

Liuwowan, northern slope of the mountains of South-west Hainan (Styan).

\section{Cinnyris RHizophor $x$.}

Cinnyris rhizophorce (Swinhoe); Shelley, Monogr. Nect.i. p. 163, pl. 52 ; Gadow, Cat. B. Brit. Mus. ix. p. 89 (1884); Styan, Ibis, 1893 , p. 430.

Arachnechthra rhizophorce, Swinhoe, Ann. Mag. N. H. (4) iv. p. 436 (1869); id. Ibis, 1870, p. 237 ; Hartl. Abh. nat. Ver. Bremen, xii. pp. 299, 309 (1892), xiv. p. 361 (1898).

Plentiful throughout Hainan, except in the neighbourhood of the capital (Swinhoe).

Hoihow, North Hainan (Hartlaub \& Styan).

38. Dichum cruentatum.

Dicaum cruentatum (Linn.); Swinhoe, Ibis, 1870, p. 239 ; Sharpe, Cat. B. Brit. Mus. x. p. 15 (1885); Hartl. Abh. nat. Ver. Bremen, 
xii. pp. 299, 309 (1892); Styan, Ibis, 1893, p. 431 ; Hartl. Abh. nat. Ver. Bremen, xiv. p. 361 (1898).

Everywhere a common species (Swinhoe).

\section{9. *DicæUM Minullum.}

Dicceum minullum, Swinhoe, Ibis, 1870 , p. 240 ; Sharpe, Cat. B. Brit. Mus. x. p. 47 (1885).

This species, hitherto known only from the unique type specimen which was dropped in the streets of London and lost (see Sharpe, Cat. B. Brit. Mus. x. p. 47, footnote), is represented by a male in the present collection.

\section{0. *ZOSTEROPS PALPEBRosa.}

Zosterops palpebrosa (Temm.); Sharpe, Cat. B. Brit. Mus. ix. p. 165 (1884).

Zosterops simplex, Swinhoe, Ibis, 1861, p. 331 (S. China); id. Ibis, 1870, p. 348 (Hainan).

Zosterops neglecta, Seebohm, Bull. B. O.C. vol. i. p. xxvi (1893); id. Ibis, 1893, pp. 219, 258 (E. Java).

The Silver-eye from China and Hainan differs somewhat from typical Z. palpebrosa from India in having the sides of the breast and the flanks much less conspicuously washed with grey.

There is an example of $Z$. palpebrosa in the British Museum Collection, labelled "Laccadives, Hume Coll." This bird is perfectly similar in plumage to $Z$. neglecta, Seebohm, from East Java. The latter appears to me to be indistinguishable from examples of Z. palpebrosa from China and Hainan-that is to say, from Z. simplex of Swinhoe.

"Iris light brown, bill black, base of lower mandible pale blue, feet greyish green." $-J$. $W$.

Met with in all parts of the island (Swinhoe).

41. *Parus cinereus.

Parus cinereus, Vieill.; Swinhoe, Ibis, 1870, p. 348 ; Gadow, Cat. B. Brit. Mus. viii. p. 16 (1883).

Three Tits from the Five-Finger Mts., Hainan, differ slightìy from typical $P$. cinereus in having the sides and flanks pure white, but this difference appears to me to be too slight to warrant their separation.

"Iris and bill black, feet greyish lead-colour."-J. W.

42. *Lanius schach.

Lanius schach, Linn.: Swinhoe, Ibis, 1870, p. 240; Gadow, Cat. B. Brit. Mus. viii. p. 261 (1883); Hartl. Abh. nat. Ver. Bremen, xii. pp. 299, 312 (1892).

" $\delta$. Iris brown, bill and feet black." $-J . W$.

Appears to be fairly common.

43. Lanius superoiliosus.

Lanius superciliosus, Lath.; Gadow, Cat. B. Brit. Mus. viii. 
p. 273 (1883) ; Hartl. Abh. nat. Ver. Bremen, xii. pp. 299, 312 (1892); Styan, Ibis, 1893, p. 429.

North Hainan (Hartlaub).

South-west Hainan (Styan).

44. Lanius fuscatus.

Lanius fuscatus, Less. ; Swinhoe, Ibis, 1870, p. 241; Gadow, Cat. B. Brit. Mus. viii. p. 263 (1883) ; Styan, Ibis, 1893, p. 429; Hartl. Abh. nat. Ver. Bremen, xiv. p. 358 (1898).

Central Hainan (Swinhoe).

Nodouha, North Central Hainan (Styan).

North Hainan (Hartlaub).

\section{Lanius Lucionensis.}

Lanius lucionensis, Linn.; Swinhoe, Ibis, 1870, p. 241 ; Gadow, Cat. B. Brit. Mus. viii. p. 274 (1883).

Lanius luzionensis, Linn. ; Hartl. Abh. nat. Ver. Bremen, xii. pp. 299, 312 (1892).

Seen, but not procured, in North and West Hainan (Swinhoe).

North Hainan (Hartlaub).

\section{6. *'TEPHRODORNIS PELVIOA.}

Tephrodornis pelvicus (Hodgs.) ; Swinhoe, Ibis, 1870, p. 241; Sharpe, Cat. B. Brit. Mus. iii. p. 376 (1877); Styan, Ibis, 1893, p. 429 ; Hartl. Abh. nat. Ver. Bremen, xiv. p. 358 (1898).

" $\delta$. Iris brown; bill black; feet brown." $-J . W$.

Central Hainan (Swinhoe).

Nodouba, North Central, and Liuwowan, northern slopes of the mountains of South-west Hainan (Styan).

North Hainan (Hartlaub).

\section{Artamus fuscus.}

Artamus fuscus, Vieill.; Swinhoe, Ibis, 1870, p. 247 ; Sharpe, Cat. B. Brit. Mus. xiii. p. 11 (1890).

Yu-lin-kan Bay, South Hainan (Swinhoe).

48. Phylloscopus plumbeitarsus.

Phyllopneuste plumbeitursus, Swinhoe, Ibis, 1870, p. 345.

Phylloscopus plumbeitarsus, Seebohm, Cat. B. Brit. Mus. v. p. 45 (1881).

West coast of Hainan towards the end of March (Swinhoe).

49. Phylloscopus superciliosus.

Reguloides supercitiosus (Gmel.); Swinhoe, Ibis, 1870, p. 345.

Phylloscopus superciliosus, Seebohm, Cat. B. Brit. Mus. v. p. 68 (1881); Hartl. Abh. nat. Ver. Bremen, xii. pp. 299, 309 (1892).

Common in February (Swinhoe).

North Hainan (Hartlaub). 
50. Lusciniola fuscata.

Phyllopneuste fuscata, Blyth ; Swinhoe, Ibis, 1870, p. 345.

Lusciniola fuscata, Seebohm, Cat. B. Brit. Mus. v. p. 127 (1881);

Hartl. Abh. nat. Ver. Bremen, xii. pp. 299, 310 (1892).

Often met with in Hainan (Swinhoe).

North Hainan (Hartlaub).

51. Cettita minuta.

Calamoherpe minuta, Swinhoe, Ibis, 1870 , p. 345.

Cettia minuta, Seebohm, Cat. B. Brit. Mus. v. p. 141 (1881); Grant, Ibis, 1894, p. 508; Hartl. Abh. nat. Ver. Bremen, xiv. p. 352 (1898).

Frequently seen and heard in February about the gardens and villages near the capital, Kiung-chu (Swinhoe).

North Hainan (Hartlaub).

52. Cetetitia canturiens.

Calanoherpe canturians, Swinhoe, Ibis, 1870 , p. 345.

Cettia canturiens, Seebohm, Cat. B. Brit. Mus. v. p. 141 (1881); Hartl. Abh. nat. Ver. Bremen, xiv. p. 352 (1898).

Common in February near Kiung-chu (Swinhoe).

North Hainan (Hartlaub).

53. Prinia extensicauda.

Drymoeca extensicauda, Swinh. Ibis, 1870, p. 345.

Prinia inornata, Sykes; Sharpe, Cat. B. Brit. Mus. vii. p. 195 (1833) ; Styan, Ibis, 1893, p. 427 ; Hartl. Abh. nat. Ver. Bremen, xiv. p. 350 (1898).

Prinia extensicauda, Oates, Faun. Brit. Ind., Birds, i.p. 454 (1889).

Common (Swinhoe).

North Hainan (Hartlaub).

South-west Hainan (Styan).

54. *Burnesia sonitans.

Prinia sonitans, Swinhoe, Ibis, 1870, p. 345.

Burnesia sonitans, Sharpe, Cat. B. Brit. Mus. vii. p. 205 (1883); Styan, Ibis, 1893, p. 427 ; Hartl. Abh. nat. Ver. Bremen, xiv. p. 351 (1898).

"Iris brown; bill black; feet pinkish brown."-J. W.

Seen about the gardens at Kiung-chu, North Hainan, and Nychu, South Hainan (Swinhoe).

Interior of Hainan (Hartlaub).

South-west Hainan (Styan).

55. Sutoria sutoria.

Sutoria sutoria (Forst.); Sharpe, Cat. B. Brit. Mus. vii. p. 215 (1883).

Orthotomus longicauda (Gmel.); Hartl. Abh. nat. Ver. Bremen, xii. pp. 299, 310 (1892).

North Hainan (Hartlaub). 
56. *Graminicola striata.

Graminicola striata, Styan, Bull. B. O. C. vol. i. p. vi (1892); id. Ibis, 1893 , p. 427 ; Hartl. Abh. nat. Ver. Bremen, xiv. p. 350 (1898).

A female specimen, collected by Whitehead, is in somewhat worn plumage; it appears to be very closely allied to $G$. bengalensis, if, indeed, it is really distinct; but the latter has the black on the head and back more pronounced and the rufous edges to the feathers less conspicuous. Many specimens of $G$. bengalensis have the feathers of the rump more or less narrowly streaked with black. I do not consider this character of much importance.

"Iris brown; bill dull pink, blackish along the culmen; feet pinkish white." $-J$. $W$.

This species is new to the British Museum Collection.

Leimumon and Leimoi, northern slope of the mountains of South-west Hainan (Styan \& Hartlaub).

57. Cisticola cisticola.

Cisticola schcenicola, Bonap.; Swinhoe, Ibis, 1870, p. 345 ; Hartl. Abh. nat. Ver. Bremen, xii. pp. 299, 310 (1892).

Cisticola cisticola (Temm.); Sharpe, Cat. B. Brit. Mus. vii. p. 259 (1883).

Grassy hills of North Hainan (Swinhoe \& Hartlaub).

58. Turdus musicus.

Turdus musicus, Linn.; Hartl. Abh. nat. Ver. Bremen, xiv. p. 346 (1898).

Hartlaub records a male from Hainan.

59. TURdus Cardis.

Turdus cardis, Temm.; Swinhoe, Ibis, 1870, p. 248; Hartl. Abh. nat. Ver. tremen, xii. pp. 299, 303 (1892).

Merula cardis, Seebohm, Cat. B. Brit. Mus. v. p. 261 (1881); Styan, Ibis, 1893, p. 427.

Kiung-chu, North Hainan, February (Swinhoe \&Hartlaub), and Tai-ping-sze, Central Hainan, 20th February (Swinhoe).

South-west Hainan (Styan).

60. Turdus chrysolaus.

Turdus chrysolaus, Temm.; Swinhoe, Ibis, 1870, p. 248.

Merula chrysolaus, Seebohm, Cat. B. Brit. Mus. v. p. 275 (1881).

Chinlan River, North-east Hainan, 6th March (Swinhoe).

61. Turdus mandarinus.

Turdus mandarinus, Bonap.; Swinhoe, Ibis, 1870, p. 248.

Merula mandarina, Seehohm, Cat. B. Brit. Mus. v. p. 238 (1881).

Merula sinensis, Hartl. Abh. nat. Ver. Bremen, xii. pp. 299, 303 (1892).

North Hainan (Swinhoe \& Hartlaub).

Occasionally seen in North-west and Central Hainan (Swinhoe). 
62. *Geocichla citrina.

Geocichla citrina (Lath.); Swinhoe, Ibis, 1870, p. 248 ; Seebohm, Cat. B. Brit. Mus. v. p. 172 (1881).

An immature male obtained on 25th April, 1899, has the earcoverts partially dusky brown.

"Iris dark brown; bill black; feet yellowish white."-J. W.

Observed by Swinhoe at Shuy-wei-sze, Central Hainan, but not obtained. Mr. Whitehead's specimen is the first that has actually been secured in Hainan.

63. Monticola solitarius.

Petrocincla manilla (Bodd.); Swinhoe, Ibis, 1870, p. 248.

Monticola solitaria (P. L. S. Müller); Seebohm, Cat. B. Brit. Mus. v. p. 319 (1881); Hartl. Abh. nat. Ver. Bremen, xii. pp. 299, 304 (1892); Styan, Ibis, 1893, p. 427.

Kiung-chu-fu and Hoihow, 27th December, North Hainan (Swinhoe \& Hartlaub); February, Lingshuy, S.E. Hainan, 11th March, Haosuy, West Hainan, 29th March (Swinhoe) ; South-west Hainan (Styan).

\section{Monticola cyanus.}

Monticola cyanus (Linn.); Seebohm, Cat. B. Brit. Mus. v. p. 316 (1881); Hartl. Abh. nat. Ver. Bremen, xii. pp. 299, 304 (1892), xiv. p. 348 (1898).

Hoihow, N. Hainan (Hartlaub).

\section{RUticilla aURorea.}

Ruticilla aurorea (Gmel.); Swinhoe, Ibis, 1870, p. 344; Seebohm, Cat. B. Brit. Mus. v. p. 345 (1881).

Gardens of Kiung-chu, February (Swinhoe).

\section{Ruticilla RUfiventris.}

Ruticilla rufiventris, Jerdon; Seebohm, Cat. B. Brit. Mus. v. p. 342 (1881); Hartl. Abh. nat. Ver. Bremen, xii. pp. 299, 306 (1892).

Dr. Hartlaub has identified a female from Hainan as belonging to this species. $R$. rufiventris is a bird of North China and Mongolia, wintering in North and Central India, and it is somewhat surprising that it should turn up in Hainan ; it is, however, very unlikely that any mistake could bave been made in the identification.

\section{Erithacus calliope.}

Erithacus calliope (Pall.); Seebohm, Cat. B. Brit. Mus. v. p. 305 (1881); Hartl. Abh. nat. Ver. Bremen, xii. pp. 299, 305 (1892); Styan, Ibis, 1893, p. 428.

North Hainan (Hartlaub).

South-west Hainan (Styan). 
68. Erithacus sibilans.

Erithacus sibilans (Swinh.); Seebohm, Cat. B. Brit. Mus. v. p. 297, pl. xvii. (1881); Hartl. Abh. nat. Ver. Bremen, xii. pp. 299, 304 (1892).

North Hainan, 15th December (Hartlaub).

69. Pratincola maura.

Pratincola indica, Swinhoe, Ibis, 1870, p. 344.

Pratincola maura, Pall.; Sharpe, Cat. B. Brit. Mus. iv. p. 188 (1879); Hartl. Abh. nat. Ver. Bremen, xii. pp. 299, 305 (1892); Styan, Ibis, 1893, p. 428; Hartl. Abh. nat. Ver. Bremen, xiv. p. 351 (1898).

Near Kiung-chu and Hoihow, North Hainan, February (Swinhoe $\&$ Hartlaub).

South-west Hainan (Styan).

70. *Copsychus saularis.

Copsychus saularis (Linn.); Swinhoe, Ibis, 1870, p. 343; Sharpe, Cat. B. Brit. Mus. vii. p. 61 (1883) ; Hartl. Abh. nat. Ver. Bremen, xii. pp. 299, 308 (1892); Styan, Ibis, 1893, p. 427.

" $\delta$. Iris dark brown; bill black; feet brown."-J. W.

Common in North and West Hainan (Swinhoe).

South-west Hainan (Styan).

71. *Cittocincla minor.

Cittacincla macrura, var. minor, Swinhoe, Ibis, 1870, p. 345.

Cittacincla tricolor, Styan, Ibis, 1893, p. 427.

Kittacincla macroura?, Hartl. Abh. nat. Ver. Bremen, xiv. p. 348 (1898).

Cittocincla brevicauda, Grant, Ibis, 1899, p. 584.

The characters which distinguish this species from C. tricolor are its somewhat smaller size (wing 3.4 inches), the brownish edges to the outer webs of the primaries, the shorter middle pair of tailfeathers, not greatly exceeding the second pair in length, and the smaller white tips to the four outer pairs.

In addition to the male obtained by Whitehead, the British Museum possesses three birds collected by Swinhoe. These differ from the type in having the middle pair of tail-feathers longer than the following pair, but agree in having the outer webs of the primaries brownish and the white tips to the tail-feathers shorter.

Central Hainan (Swinhoe).

Nodouho, interior of North Hainan (Styan \& Hartlaub).

72. *Henicurus sinensis.

Henicurus sinensis, Gould; Sharpe, Cat. B. Brit. Mus. vii. p. 313 (1883).

ㅇ. "Iris and bill black; feet pinkish white."-J. $W$.

This species is recorded for the first time from Hainan. 
Besides adults the collection contains a quite young bird, apparently just fledged, in an interesting stage of plumage.

73. *TROChaLOPTERON CANORUM.

Leucodiopterum sinense (Gmel.); Swinhoe, Ibis, 1870, p. 250.

Trochalopteron canorum (Linn.); Sharpe, Cat. B. Brit. Mus. vii. p. 376 (1883); Styan, Ibis, 1893, p. 427 ; Hartl. Abh. nat. Ver. Bremen, xiv. p. 348 (1898).

"Iris greenish yellow; bill yellow-red-brown; feet pinkish brown."-J. $W$.

Interior of Hainan (Swinhoe).

Interior of South-west Hainan (Styan \& Hartlaub).

74. *Garrulax semitorquata, sp. n.

Adult male. Most nearly allied to G. pectoralis (Gould), having the ear-coverts similarly striped. It is, however, much smaller and at once distinguished by the following characters:- the black band surrounding the throat is widely interrupted in the middle, the outer webs of the outer primary-quills are brownish buff instead of white, and the tips of the tail-feathers are fulvous buff.

Adult female. Differs from the male only in having the white streaks on the ear-coverts more strongly marked.

"Iris straw-colour to reddish brown; upper mandible lead-black, lower and feet lead-grey."- $J$. $W$.

Total length about $11 \cdot 0$ inches; culmen $1 \cdot 25$; wing $5 \cdot 1$; tail $4 \cdot 8$; tarsus $1 \cdot 75$.

Hab. Five-Finger Mts., interior of Hainan.

75. *GarRULAX schmaCKeri.

Garrulax moniliger, Styan (nec Hodgs.), Ibis, 1893, p. 427.

Garrulax schmackeri, Hartl. Abh. nat. Ver. Bremen, xiv. p. 349 (1898).

This species evidently belongs to the more slender-billed group and is closely allied to G. moniliger (Hodgs.), having the ear-coverts similarly coloured. It is, however, an altogether smaller bird and may be at once distinguished by the wide bright fulvous tips to the tail-feathers. The adult has the base of the fore-neck tinged with buff, while in a quite young bird this part is pure white; in other respects the plumage of the young bird does not differ from that of the adult.

This species is new to the British Museum Collection.

G. schmackeri: culm. $1 \cdot 05$ in.; wing $4 \cdot 2-4 \cdot 3$; tail $4 \cdot 5$; tarsus $1 \cdot 5$. G. moniliger: $\quad, 1.2$ in.; " $4 \cdot 8-5 \cdot 0 ;, 4.9$; , $1 \cdot 7$. Interior of South-west Hainan (Styan \& Hartlaub).

76. *Dryonastes Castanotis.

Dryonastes castanotis, Grant, Ibis, 1899, p. 584.

This very distinct species is perhaps most nearly allied to D. rufin collis from India.

The general colour above is slate-grey, tinged with greenish on 
the lower back and upper tail-coverts; the lores and feathers surrounding the eye and on the fore part of the cheek black; the hinder part of the cheek and ear-coverts with a large rounded patch of bright chestnut; the chin, throat, and upper part of the chest brownish black; and the rest of the underparts grey, tinged with greenish on the flanks, thighs, and under tail-coverts.

"Bill and eye black; legs and feet dark blackish brown."-J. W. Total length $10 \cdot 7$ inches; wing $5 \cdot 0$; tail $5 \cdot 0$; tarsus $1 \cdot 75$.

$\mathrm{Hab}$. Five-Finger Mts., interior of Hainan.

77. *Dryonastes monachus.

Garrulax monachus, Swinhoe, Ibis, 1870, p. 248 ; Hartl. Abh. nat. Ver. Bremen, xii. pp. 299, 309 (1892).

Dryonastes monachus, Sharpe, Cat. B. Brit. Mus. vii. p. 457 (1883) ; Styan, Ibis, 1893, p. 427.

"Iris brown; bill black; legs and feet dusky black."-J. W.

Interior of Hainan (Swinhoe).

South-west Hainan (Styan).

78. *Pomatorhinus nigrostellatus.

Pomatorhinus nigrostellatus, Swinhoe, Ibis, 1870, p. 250; Sharpe, Cat. B. Brit. Mus. vii. p. 425(1883); Hartl. Abh. nat. Ver. Bremen, xii. pp. 299, 308 (1892); Styan, Ibis, 1893, p. 427.

Pomatorhinus musicus, Hartl. Abh. nat. Ver. Bremen, xiv. p. 348 (1898) (part., Hainan).

This species, though nearly allied to the Chinese form P. stridulus, Swinh., may be at once distinguished by the dark olive colour of the upper parts and the deep reddish-brown middles to the feathers of the fore-neck and chest.

"Tip of upper and lower mandible straw-yellow; iris pale brown; feet dark brown."- $J$. $W$.

Central Hainan (Swinhoe).

Interior of South-west Hainan (Styan).

79. *StaChYRIDOPSIS RUFICEPS.

Stachyrhis prcecognitus, Swinhoe, Ibis, 1866, p. 310 (Formosa).

Stachyridopsis ruficeps (Blyth); Sharpe, Cat. B. Brit. Mus. vii. p. 598 (1883).

This is the first time this species has been recorded from Hainan.

There appear to be three fairly well-marked races of S. ruficeps :-

$a$. Typical examples from India with the cap extending over the nape, and of the pale chestnut-colour characteristic of Chinese birds.

$b$. Chinese examples with the cap confined to the crown and generally of a pale chestnut-colour.

c. Birds from Formosa and Hainan with the cap of a deeper chestnut-colour and extending on to the nape. This is the form which has been described as S. procognitus by Swinhoe.

"Iris deep lake; upper mandible black, lower white; legs greyish yellow." $-J . W$. 
80. *ALCIPPE MORRISONIANA.

Alcippe morrisoniana, Swinh.; Sharpe, Cat. B. Brit. Mus. vii. p. 621 (1883).

Alcippe morrisonia, Swinh.; Styan, Ibis, 1893, p. 428 ; Hartl. Abh. nat. Ver. Bremen, xiv. p. 350 (1898).

"Iris lake-brown; bill black; feet brownish yellow."-J. W.

Interior of South-west Hainan (Styan \& Hartlaub).

\section{1. *HERPoRNis TYRANNULUS.}

Herpornis tyrannulus, Swinhoe, Ibis, 1870 , p. 347, pl. x.; Sharpe, Cat. B. Brit. Mus. vii. p. 637 (1883); Styan, Ibis, 1893, p. 428; Hartl. Abh. nat. Ver. Bremen, xiv. p. 353 (1898).

Cryptolopha bicolor, Styan, Bull. B. O. C. vol. i. p. vi (1892); id. Ibis, 1893 , p. 55.

$J . W$.

"Iris black; bill pink; ridge of culmen brown ; feet pink." -

Central Hainan (Swinhoe).

Interior of South-west Hainan (Styan).

Hummocks, North Hainan (Hartlaub).

\section{2. *Pycnonotus hainanus.}

Ixus hainanus, Swinhoe, Ibis, 1870 , p. 253 ; Hartl. Abh. nat. Ver. Bremen, xii. pp. 299, 308 (1892).

Pycnonotus hainanus, Swinhoe; Sharpe, Cat. B. Brit. Mus. vi. p. 150 (1881); Styan, Ibis, 1893, p. 428; Hartl. Abh. nat. Ver. Bremen, xiv. p. 355 (1898).

"Iris, bill, and feet black."- $J$. W.

Throughout Hainan and the adjacent island of Naochu (Swinhoe).

\section{3. *Hemixus castanonotus.}

Hemixus castanonotus, Swinhoe, Ibis, 1870 , p. 251, pl. ix. fig. 1 ; Sharpe, Cat. B. Brit. Mus. vi. p. 51 (1881); Seebohm, P.Z. S. 1890 , pl. xxvii. fig. 2 (breast wrongly coloured); Styan, Ibis, 1893, p. 428 ; Hartl. Abh. nat. Ver. Bremen, xiv. p. 355 (1898).

Swinhoe's type specimen, as figured by Seebohm, has had the breast stained with some brownish matter; hence the plate, as pointed out by $\mathrm{Mr}$. Styan, is misleading.

ס. " Iris hazel; bill black ; feet brownish black."-J. $W$.

Tai-ping-sze and Lingmun, Central Hainan (Swinhoe).

Interior of South-west Hainan (Styan).

\section{Spizixus CINEREICAPILLUS.}

Spizixus cinereicapillus, Swinhoe ; Sharpe, Cat. B. Brit. Mus. vi. p. 173 (1881); Hartl. Abh. nat. Ver. Bremen, xii. pp. 299, 308 (1892).

Hartlaub records the occurrence of this species in Hainan.

Proc. Zool. Soc.-1900, No. XXXII. 
85. *HYPSIPETES PERNIGER.

Hypsipetes perniger, Swinhoe, Ibis, 1870 , p. 251, pl. ix. fig. 2 ; Sharpe, Cat. B. Brit. Mus. vi. p. 41 (1881); Hartl. Abh. nat. Ver. Bremen, xii. pp. 209, 307 (1892); Styan, Ibis, 1893, p. 429 ; Hartl. Abh. nat. Ver. Bremen, xiv. p. 355 (1898).

๙. "Iris brown ; bill, legs, and feet vermilion." $-J . W$.

North Hainan (Swinhoe, Styan, \& Hartlaub).

Central and South Hainan (Swinhoe).

86. * Criniger palLidus.

Criniger pallidus, Swinhoe, Ibis, 1870, p. 252 ; Sharpe, Cat. B. Brit. Mus. vi. p. 81 (1881); Sharpe, Bull. B. O. C. vol. i. p. xix (1892); Styan, Ibis, 1893, p. 429; Hartl. Abh. nat. Ver. Bremen, xiv. p. 356 (1898).

Pinarocichla schmackeri, Styan, Bull. B. O. C. vol. i. p. vi (1892); id. Ibis, 1893, p. 54.

"Iris brown; upper mandible brown, lower blue-grey; feet pinkish brown."-J. $W$.

Central and South Hainan (Swinhoe).

Northern slopes of the mountains of South-west Hainan (Styan).

\section{7. * ChLoRopsis LazULINA.}

Phyllornis lazulina, Swinhoe, Ibis, 1870, p. 255 ; Hartl. Abh. nat. Ver. Bremen, xiv. p. 356 (1898).

Chloropsis lazulina (Swinh.) ; Sharpe, Cat. B. Brit. Mus. vi. p. 19 (1881) ; Styan, Ibis, 1893, p. 429.

o. "Iris dark brown; bill black; feet lead-grey."-J. W.

Central and South Hainan (Swinhoe).

Northern slopes of the mountains of South-west Hainan (Styan).

88. *Campophaga saturata.

Volvocivora saturata, Swinhoe, Ibis, 1870, p. 242.

Campophaga saturata (Swinh.); Sharpe, Cat. B. Brit. Mus. iv. p. 66 (1879); Styan, Ibis, 1893, p. 429; Hartl. Abh. nat. Ver. Bremen, xiv. p. 357 (1898).

ơ. "Iris brown; bill black; feet dusky black."-J. W.

Throughout Hainan (Swinhoe).

89. *Graudalus maciI.

Graucalus macii, Lesson; Sharpe, Cat. B. Brit. Mus. iv. p. 34 (1879); Styan, Ibis, 1893 , p. 429 ; Swinhoe (nec Swinh. 1863), Ibis, 1870 , p. 242.

Graucalus rex pineti, Hartl. (nec Swinh.), Abh. nat. Ver. Bremen, xiv. p. 357 (1898).

ㅇ moulting. " "Iris dark brown ; bill and feet black." $-J . W$. Tai-ping-sze, Central Hainan (Swinhoe).

Northern slope of the mountains of South-west Hainan (Styan). 
90. Pericrocotus cantonensis.

Pericrocotus cantonensis, Swinhoe, Ibis, 1870 , p. 244 (Nao-chu); Sharpe, Cat. B. Brit. Mus. iv. p. 84 (1879).

This species, though found on the adjacent island of Nao-chu, has not yet been met with in Hainan.

\section{1. *Pericrocotus fraterculus.}

Pericrocotus fraterculus, Swinhoe, Ibis, 1870, p. 244 ; Oates, Faun. Brit. India, Birds, i. p. 481 (1889).

Pericrocotus elegans, Sharpe (nec M‘Clell.), Cat. B. Brit. Mus. iv. p. 73 (1879) ; Hartl. Abh. nat. Ver. Bremen, xii. pp. 299, 307 (1892); Styan, Ibis, 1893, p. 429 ; Hartl. Abh. nat. Ver. Bremen, xiv. p. 358 (1898).

o. " Iris, bill, and feet black." $-J . W$.

Common on all parts of the island (Swinhoe).

92. *Pericrocotud griseigularis.

Pericrocotus griseigularis, Gould ; Sharpe, Cat. B. Brit. Mus. iv. p. 83 (1879).

o. "Iris, bill, and feet black."- $J$. $W$.

A male from Hainan appears to belong to the typical form from Formosa. Continental birds from China seem to differ from typical examples from Formosa in having the top of the head and back greyer, and they are, moreover, somewhat larger.

This is the first time this species has been recorded from Hainan.

93. Pericrocotus cinereus.

Pericrocotus cinereus, Lafr.; Swinhoe, Ibis, 1870, p. 244 (Naochu); Sharpe, Cat. B. Brit. Mus. iv. p. 83 (1879).

This species was procured by Swinhoe on the adjacent island of Nao-chu, but has not yet been found in Hainan itself.

94. Hemichelidon SIBIRICA.

Hemichelidon sibirica (Gmel.); Sharpe, Cat. B. Brit. Mus. iv. p. 120 (1879); Hartl. Abh. nat. Ver. Bremen, xiv. p. 359 (1898).

Hartlaub records a male from Hoihow, North Hainan.

95. Hemichelidon ferrugineus.

Butalis ferruginea (Hodgs.); Swinhoe, Ibis, 1870, p. 247.

Hemichetidon ferrugineus, Sharpe, Cat. B. Brit. Mus. iv. p. 122 (1879).

West coast of Hainan, 29th and 30th March (Swinhoe).

96. Alseonax latirostris.

Butalis cinereoalba (T. \& S.); Swinhoe, Ibis, 1870, p. 247.

Alseonax latirostris (Raffl.); Sharpe, Cat. B. Brit. Mus. iv. p. 127 (1879); Styan, Ibis, 1893, p. 430.

Gardens about Kiung-chu-fu, North Hainan, February (Swinhoe). South-west Hainan (Styan). 
97. Muscicapa albicilla.

Erythrosterna leucura (Swains.); Swinhoe, Ibis, 1870, p. 247.

Muscicapa albicilla, Pall.; Sharpe, Cat. B. Brit. Mus. iv. p. 162 (1879) ; Styan, Ibis, 1893, p. 430 ; Hartl. Abh. nat. Ver. Bremen, xiv. p. 359 (1898).

Tai-ping-sze, Central Hainan, 19th February (Swinhoe).

South-west Hainan (Styan).

Hoihow, North Hainan (Hartlaub).

98. Poliomyias luteola.

Erythrosterna mugimaki (Temm.) ; Swinhoe, Ibis, 1870, p. 247.

Poliomyias luteola (Pall.); Sharpe, Cat. B. Brit. Mus. iv. p. 201 (1879).

On the adjacent island of Nao-chu, 5th April (Swinhoe).

99. *Xanthopygia Narcissina.

Xanthopygia narcissina (Temm.); Swinhoe, Ibis, 1870, p. 247 ; Sharpe, Cat. B. Brit. Mus. iv. p. 249 (1879).

Swinhoe records this species from the adjacent island of Nao-chu on the 5th April.

This is the first time this species has been procured on Hainan.

100. * XaNTHOPYGIA CYANOMELANA.

Cyanoptila cyanomelaena (T. \& S.); Swinhoe, Ibis, 1870, p. 247.

Xanthopygia cyanomelaena, Sharpe, Cat. B. Brit. Mus. iv. p. 251 (1879).

Niltava cyanomelcena, Hartl. Abh. nat. Ver. Bremen, xii. pp. 299, 306 (1892).

Haosuy, West Hainan, 29th March, and adjacent island of Nao-chu, 5th April (Swinhoe).

101. *Xanthopygia fUliginosa.

Xanthopygia fuliginosa (Vig.); Sharpe, Cat. B. Brit. Mus. iv. p. $253(1879)$.

‥ "Iris and feet dark brown; bill black."-J. W.

This is the first time this widely distributed Indo-Chinese species has been met with in Hainan, where it is evidently a resident and breeds. Young birds just able to fly were among those sent home.

\section{2. *Siphia haINANa.}

Siphia pallidipes (Jerd.)?; Styan, Ibis, 1893, p. 430 ; Hartl. Abh. nat. Ver. Bremen, xiv. p. 359 (1898).

Siphia hainana, Grant, Bull. B. O. C. vol. x. p. xxxvi (1900).

Adult male. Allied to male of S. pallidipes (Jerd.), but much smaller. The blue on the upper parts darker and brighter; the forehead and superciliary stripes bright cobalt-blue; flanks and sides of belly grey, slightly washed with fulvous.

"Iris and bill black; feet dusky black."-J. W. 
Adult female. Differs conspicuously from the female of S. pallidipes (Jerd.), the general colour of the head and upper parts being darker and more uniform, the upper tail-coverts and outer webs of the tail-feathers being olive-brown tinged with rufous instead of chestnut; but the most conspicuous difference is to be found in the colour of the throat, fore-neck, and chest, which are pale rust-colour instead of deep orange-rust.

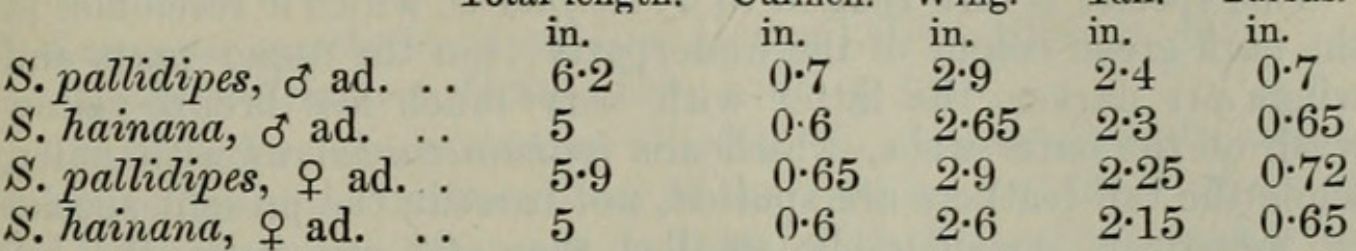

Mr. Styan records examples from Leimumon on the northern slopes of the mountains of South-west Hainan and from Nodouba in the interior of Northern Hainan.

\section{3. * Hүротhymis azUREA.}

Myiagra azurea (Bodd.); Swinhoe, Ibis, 1870, p. 247.

Hypothymis azurea, Sharpe, Cat. B. Brit. Mus. iv. p. 274 (1879); Hartl. Abh. nat. Ver. Bremen, xii. pp. 299, 307 (1892).

Hypothymis occipitalis (Vig.); Styan, Ibis, 1893, p. 430 ; Hartl. Abh. nat. Ver. Bremen, xiv. p. 360 (1898).

Common (Swinhoe).

104. RHIPIDURA ALBICOLlis.

Rhipidura albicollis (Vieill.); Sharpe, Cat. B. Brit. Mus. iv. p. 317 (1879); Styan, Ibis, 1893, p. 430 ; Hartl. Abh. nat. Ver. Bremen, xiv. p. 360 (1898).

Styan records this species from Hainan.

105. *TERPSIPHONE PRINCEPS.

Terpsiphone princeps (Temm.); Sharpe, Cat. B. Brit. Mus. iv. p. 361 (1879) ; Styan, Ibis, 1893, p. 430.

o. " Iris black; orbital skin and bill rich cobalt-blue, inclining to purple; feet cobalt." $-J . W$.

Hoihow, North Hainan, 10th October (Styan).

106. *Cryptolopha fulvifacies.

Cryptolopha fulvifacies, Swinh.; Sharpe, Cat. B. Brit. Mus. iv. p. 406 (1879).

o. "Iris dark brown; upper mandible brown, lower dull yellow; feet brownish yellow." $-J . W$.

This is the first time this little Flycatcher has been recorded from Hainan.

107. Hirundo gutturalis.

Hirundo gutturalis, Scop.; Swinhoe, Ibis, 1870, p. 240 ; Sharpe, Cat. B. Brit. Mus. x. p. 134 (1885).

Recorded by Swinhoe from all parts of the coast of Hainan. 


\section{8. *Gecinus hainands.}

Gecinus hainanus, Grant, Ibis, 1899, p. 584.

This species is most nearly allied to G. guerini (Malh.) from China, but distinguished by the darker green colour of the upper and under parts; in G. guerini the general colour of the upper parts is dull greyish green and the underparts are similarly coloured, but paler, inclining to whitish grey tinged with green.

This species is also related to G. occipitalis, which it resembles in the dark green colour of the underparts; but the upper parts and wings are darker, the latter with very much less bronze-yellow wash on the outer webs, which are indistinctly barred with paler, while the tail-feathers are spotted, not barred ; the present species is, moreover, considerably smaller than $G$. occipitalis, the bill especially being shorter and less stout.

\begin{tabular}{llll} 
& $\begin{array}{c}\text { Culmen. } \\
\text { in. }\end{array}$ & $\begin{array}{c}\text { Wing. } \\
\text { in. }\end{array}$ & \multicolumn{1}{c}{$\begin{array}{l}\text { Tail. } \\
\text { in. }\end{array}$} \\
G. hainanus, o adult (type).. & $1 \cdot 5$ & $5 \cdot 3$ & $3 \cdot 8$ \\
G. occipitatis, o adult . . . . . & $1 \cdot 7$ & $5 \cdot 6-5 \cdot 9$ & $4 \cdot 2-4 \cdot 5$
\end{tabular}

$H a b$. Five-Finger Mts., interior of Hainan.

"Iris white; bill grey-black, base greenish white; feet leadgrey." $-J . W$.

\section{9. *Chrysophlegma styani.}

Chrysophlegma styani, Grant, Ibis, 1899, p. 585.

This species is most nearly allied to $C$. wrayi Sharpe and C. ricketti Styan. From the latter it differs in being much smaller and in having the terminal part of the outer primaries mostly uniform black, as in C. wrayi. From C. wrayi it may be at once distinguished by its larger size and by the dark brownish-chestnut crown, the pale (Californian) gold nuchal crest, and the dark smokegrey underparts; in these respects it resembles $C$. ricketti.

The female of $C$. styani further differs from the female (type) of $C$. wrayi in having the feathers of the middle of the throat paler brown and margined with rufous instead of white.

$\begin{array}{ll}\text { Wing. } & \text { Tail. } \\ \text { in. } & \text { in. }\end{array}$

Type of $C$. ricketti $\ldots \ldots \ldots \ldots \ldots, 6 \cdot 8 \quad 5 \cdot 2$

Type of $C$. styani $\ldots \ldots \ldots \ldots \ldots, 6 \cdot 0 \quad 4 \cdot 5$

$\begin{array}{llll}\text { Type of } C \text {. wrayi } \ldots \ldots \ldots \ldots \ldots & 5 \cdot 6 & 4 \cdot 0\end{array}$

" Iris dark claret; bill dusky black, lower mandible green at base ; feet olive-green." $-J$. $W$.

$H a b$. Five-Finger Mts., interior of Hainan.

\section{0. *Dendrocopus CABANisi.}

Picus cabanisi, Gould, B. Asia, vi. pl. xvii. (1857).

Dendrocopus cabanisi (Malh.); Hargitt, Cat. B. Brit. Mus. xviii. p. 218 (1890) ; Styan, Ibis, 1893, p. 431. 
Picus mandarinus, Malh.; Swinhoe, Ibis, 1870, p. 94 ; Hartl. Abh. nat. Ver. Bremen, xiv. p. 366 (1898).

"Iris brown; bill lead-black ; feet brownish black."-J. $W$.

Yulinkan Bay, South Hainan (Swinhoe).

South-west Hainan (Styan).

Interior of North Hainan (Hartlaub).

\section{1. *Lepocestes hainanus.}

Lepocestes pyrrhotis, Styan (nec Hodgs.), Ibis, 1893, p. 431.

Lepocestes hainanus, Grant, Ibis, 1899, p. 585.

This species is most nearly allied to $L$. sinensis Rickett, which it resembles in the darker colour of the mantle; but the feathers of the lower back and rump are dark brown, indistinctly tipped with rufous, never barred with buff; the chin and throat are more rufous; the general colour of the underparts less dark; and the flanks and under tail-coverts uniform without any traces of bars. The black bars on the wings and tail-feathers are wider apart and less numerous.

$J . W$.

"Iris brown; bill straw-yellow; legs dull blackish brown."-

\section{2. *IYNGIPICUS KALEENSIS.}

Picus kaleensis, Swinhoe, Ibis, 1870, p. 95.

Iyngipicus kaleensis, Swinh.; Hargitt, Cat. B. Brit. Mus. xviii. p. 315 (1890) ; Styan, Ibis, 1893, p. 431; Hartl. Abh. nat. Ver. Bremen, xiv. p. 366 (1898).

"Iris dark brown; bill slate-grey, whitish at base of lower mandible; feet olive-green."--J. $W$.

Central Hainan (Swinhoe).

Interior of South-west Hainan (Styan).

Interior of North Hainan (Hartlaub).

\section{Micropternus Holroydi.}

Micropternus holroydi, Swinhoe, Ibis, 1870, p. 95 ; Hargitt, Cat. B. Brit. Mus. xviii. p. 403 (1890); Styan, Ibis, 1893, p. 431 ; Hartl. Abh. nat. Ver. Bremen, xiv. p. 366 (1898).

Central Hainan (Swinhoe).

Nodouha, interior of North Hainan, May (Styan \& Hartlaub).

\section{4. *Cyanops Faber.}

Megalcema faber, Swinhoe, Ibis, 1870, p. 96, pl.iv. fig. 1; Hartl. Abh. nat. Ver. Bremen, xii. pp. 299, 317 (1892), xiv. p. 367 (1898).

Cyanops faber, Shelley, Cat. B. Brit. Mus. xix. p. 75 (1891); Styan, Ibis, 1893 , p. 432.

o. " Iris brown; upper mandible black, lower greyish at base, terminal half black; feet green-olive." $-J . W$.

Central Hainan (Swinhoe).

Nodouha, interior of North Hainan (Styan $\&$ Hartlaub). 


\section{5. *Paleornis fasciata.}

Palceornis javanica, Swinh. (nec Osb.), Ibis, 1870, p. 93.

Palcoornis fasciata (Müll.); Salvad. Cat. B. Brit. Mus. xx. p. 464 (1891); Styan, Ibis, 1893, p. 433.

Palcoornis lathami, Finsch; Hartl. Abh. nat. Ver. Bremen, xii. pp. 299, 322 (1892), xiv. p. 368 (1898). J. $\stackrel{+}{W}$.

‥ "Iris pale straw-yellow; bill black; feet olive-green."-

Tai-ping-sze, Central Hainan, and near Hao-suy Harbour, Northwest Hainan (Swinhoe).

Nam-fung, interior of North Hainan, 26th May ; Ting-on, 13th January, and Leimumon, northern slope of the mountains of South-west Hainan (Styan).

\section{6. *CuCulus Micropterus.}

Cuculus micropterus, Gould; Shelley, Cat. B. Brit. Mus. xix. p. 241 (1891); Styan, Ibis, 1893, p. 433; Hartl. Abh. nat. Ver. Bremen, xiv. p. 368 (1898).

o. " Iris dark brown; orbital skin, feet, and gape bright yellow; lower mandible greenish, upper blackish grey."-J. $W$.

Interior of South-west Hainan (Styan).

Interior of North Hainan (Hartlaub).

\section{Cacomantis merulinus.}

Polyphasia tenuirostris, Swinhoe, Ibis, 1870, p. 230.

Cacomantis merutinus (Scop.); Shelley, Cat. B. Brit. Mus. xix. p. 268 (1891); Hartl. A bh. nat. Ver. Bremen, xii. pp. 299, 319 (1892).

Near Kiung-chu, North Hainan, February and March (Swinhoe). North Hainan, December and March (Hartlaub).

\section{8. * Chalcococcix maculatus.}

Chalcococcyx maculatus (Gmel.); Shelley, Cat. B. Brit. Mus. xix. p. 291 (1891).

o. "Iris red-brown; bill orange, tip black; feet brownish green." $-J . W$.

This species is new to Hainan.

\section{Eudynamis honorata.}

Eudynamis malayana, Cab. \& Heine; Swinhoe, Ibis, 1870, p. 231. Eudynamis honorata (Linn.); Shelley, Cat. B. Brit. Mus. xix. p. 316 (1891) ; Hartl. Abh. nat. Ver. Bremen, xii. pp. 299, 318 (1892); Styan, Ibis, 1893, p. 433.

Eudynamis maculatus (Gmel.); Hartl. Abh. nat. Ver. Bremen, xiv. p. 368 (1898).

Common throughout Hainan (Swinhoe). 


\section{0. *Centropus sinensis.}

Centropus viridis, Swinhoe (nec Scop.), Ibis, 1870, p. 235.

Centropus rufipennis, Swinhoe (nec Illiger), Ibis, 1870, p. 234.

Centropus sinensis (Steph.); Shelley, Cat. B. Brit. Mus. xix. p. 343 (1891); Hartl. Abh. nat. Ver. Bremen, xii. pp. 299, 318 (1892), xiv. p. 368 (1898).

"Iris lake-red; bill and feet black."-J. W.

Common throughout Hainan (Swinhoe).

121. Centropus bengalensis.

Centropus bengalensis (Gmel.); Shelley, Cat. B. Brit. Mus. xix. p. 352 (1891); Styan, Ibis, 1893, p. 433.

Interior of South-west Hainan (Styan).

122. *RHOPODYTES TRISTIS.

Rhopodytes tristis (Less.); Shelley, Cat. B. Brit. Mus. xix. p. 386 (1891) ; Styan, Ibis, 1893, p. 433.

Zanclostomus tristis, Swinhoe, Ibis, 1870, p. 234 ; Hartl. Abh. nat. Ver. Bremen, xii. pp. 299, 318 (1892), xiv. p. 367 (1898).

o. " Iris dark brown; bill dull emerald-green ; orbital skin dull scarlet; feet dull bluish olive-green."-J. $W$.

Central, South-east, and South Hainan (Swinhoe).

Leimumon, northern slopes of the mountains of South-west Hainan (Styan).

\section{3. *Harpactes hainanus.}

Harpactes erythrocephalus, Styan (nec Gould), Ibis, 1893, p. 433.

Harpactes hainanus, Grant, Bull. B. O. C. vol.x. p. xxxvii (1900).

Adult male. Differs from the male of $H$. erythrocephatus in having the head dull purplish crimson, not shading into crimson-scarlet on the nape ; the upper parts much browner, especially the mantle and upper back, and with very little trace of chestnut on the lower back, rump, and upper tail-coverts, the latter being dark chestnut; the lower part of the chest, next the white band, dull crimson instead of scarlet-crimson. In addition to the above differences, the white tips to the outer tail-feathers are shorter, the longest scarcely exceeding $1 \cdot 1$ inch. From $H$. yamakanensis Rickett, from Fohkien, the Hainan bird may be at once distinguished by the colour of the upper parts.

Iris hazel; bill black, base and orbital skin dark purplish French blue ; feet pinkish brown.

o. Total length 12 inches; wing $5 \cdot 5$; tail 6 .

Adult female. Differs from the female of $H$. erythrocephalus in having the general colour of the upper parts and chest much browner.

ㅇ. Total length 12 inches; wing $5 \cdot 3$; tail $5 \cdot 7$.

This species has already been obtained by Mr. Schmaker's collector Tetsu at Leimumon, on the northern slopes of the mountains of South-west Hainan, but was identified by Mr. Styan with H. erythrocephalus, Gould. 
124. Cypselus pacificus.

Cypselus pacificus, Lath. ; Swinhoe, Ibis, 1870, p. 89.

Micropus pacificus, Hartert, Cat. B. Brit. Mus. xvi. p. 448 (1892). Apus pacificus, Hartert, Das Tierreich, Macropt. p. 86 (1897).

Observed in large numbers in Nychow Harbour, South Hainan (Swinhoe).

\section{Cypselus subfurcatus.}

Cypselus subfurcatus, Blyth; Swinhoe, Ibis, 1870, p. 89 ; Hartl. Abh. nat. Ver. Bremen, xiv. p. 361 (1898).

Micropus subfurcatus, Hartert, Cat. B. Brit. Mus. xvi. p. 456 (1892).

Apus subfurcatus, Hartert, Das Tierreich, Macropt.p. 88 (1897).

North and South Hainan (Swinhoe \& Hartlaub).

126. TACHORNIS INFUMATA.

Cypselus tinus, Swinhoe, Ibis, 1870, p. 90.

Tachornis infumatus (Sclat.); Hartert, Cat. B. Brit. Mus. xvi. p. 467 (1892).

Central, South-east, and South Hainan (Swinhoe).

127. * CAPRIMULGUS JOTAKA.

Caprimulgus jotaka, Temm. \& Schleg.; Swinhoe, Ibis, 1870, p. 89 (Nao Chau) ; Hartert, Cat. B. Brit. Mus. xvi. p. 552 (1892).

Caprimulgus indicus jotaka, Hartert, Das Tierreich, Caprimulg. p. 61 (1897).

The two specimens collected by Whitehead, though considerably different one from another, agree in general characters with typical C. jotaka, but are somewhat smaller :--

a. Wing $7 \cdot 1$ inches; tail $4 \cdot 4$.

b. " $7 \cdot 8$, ; , $5 \cdot 1$.

The smaller bird has the general colour of the head, wing-coverts, and scapulars grey, and in this respect, as well as in the larger white markings on the four outer quills, differs considerably from $b$, the latter having many more of the feathers of the crown largely mixed with black, while the scapulars and wing-coverts are more conspicuously marked with black and rufous. Both Whitehead's birds belong to the smaller form obtained by Swinhoe on the adjacent island of Nao Chau.

128. Merops sumatranus.

Merops sumatranus, Raffl.; Sharpe, Cat. B. Brit. Mus. xvii. p. 61 (1892); Styan, Ibis, 1893, p. 432.

Two immature birds from the Hummocks, North Hainan, 18th September (Styan).

129. *NyctionNis ATHERTONI.

Nyctiornis athertoni (Jard. \& Selby); Sharpe, Cat. B. Brit. Mus. xvii. p. 88 (1892). 
"Iris dark brown; bill black, base of lower mandible grey; feet dull yellow."-J. $W$.

This is the first time this species has been recorded from Hainan.

130. *UPUPA INDICA.

Upupa indica, Reichenb.; Salvin, Cat. B. Brit. Mus. xvi. p. 10 (1892); Styan, Ibis, 1893, p. 432.

Upupa ceylonensis, Reichb.; Swinhoe, Ibis, 1870, p. 91 ; Hartl. Abh. nat. Ver. Bremen, xii. pp. 299, 318 (1892), xiv. p. 367 (1898).

"Iris black; bill dusky black, pinkish at base; feet dusky brown."-J. W.

Common throughout Hainan (Swinhoe).

\section{Ceryle varia.}

Ceryle rudis, Swinhoe (nec Linn.), Ibis, 1870, p. 92 ; Styan, Ibis, 1893, p. 433 ; Hartl. Abh. nat. Ver. Bremen, xiv. p. 367 (1898).

Ceryle varia (Strickl.); Sharpe, Cat. B. Brit. Mus. xvii. p. 112 (1892); Hartl. Abh. nat. Ver. Brem. xii. pp. 299, 319 (1892).

Common throughout Hainan (Swinhoe).

132. * CeRYLE LUGUBRIS.

Ceryle lugubris (Temm.); Sharpe, Cat. B. Brit. Mus. xvii. p. 115 (1892).

Ceryle guttata, Vigors ; Styan, Ibis, 1893, p. 433.

"Bill lead-black; feet dark brown."-J. $W$.

Interior of South-west Hainan (Styan).

133. *ALCEDO ISPIDA.

Alcedo bengalensis, Gmel.; Swinhoe, Ibis, 1870 , p. 92.

Alcedo ispida, Linn.; Sharpe, Cat. B. Brit. Mus. xvii. p. 141 (1892).

o imm. "Iris brown; bill black ; feet brown, soles yellow."J. $W$.

Common in all open country (Swinhoe).

134. *ALCEDo GRANDIS.

Alcedo grandis, Blyth; Sharpe, Cat. B. Brit. Mus. xvii. p. 156 (1892).

Adult ${ }^{\circ}$. "Iris dark brown; upper bill black, lower dull red; feet coral-red." $-J$. $W$.

This is the first time that this very rare species has been met with outside Northern India.

135. * Ceyx tridactyla.

Ceyx tridactyla (Pall.); Sharpe, Cat. B. Brit. Mus. xvii. p. 174 (1892).

This species has not previously been met with in Hainan. 


\section{6. *HaLCYON SMYrRensis.}

Halcyon smyrnensis (Linn.); Swinh. Ibis, 1870, p. 93; Sharpe, Cat. B. Brit. Mus. xvii. p. 222 (1892); Hartl. Abh. nat. Ver. Bremen, xii. pp. 299, 319 (1892); Styan, Ibis, 1893, p. 433; Hartl. Abh. nat. Ver. Bremen, xiv. p. 367 (1898).

Once met with at Haosuy, North-west Hainan (Swinhoe).

Interior of South-west Hainan (Styan).

Hoihow, North Hainan (Hartlaub).

137. Halcyon pileatus.

Halcyon pileatus (Bodd.); Swinhoe, Ibis, 1870, p. 93; Sharpe, Cat. B. Brit. Mus. xvii. p. 229 (1892); Styan, Ibis, 1893, p. 433; Hartl. Abh. nat. Ver. Bremen, xiv. p. 367 (1898). (1892).

Entomobia pileata, Hartl. Abh. nat. Ver. Brem. xii. pp. 299, 319

Haosuy, North-west Hainan, and the adjacent island of Nao-chu.

Interior of South-west Hainan (Styan).

Hoihow, North Hainan (Hartlaub).

138. *Eurystomus CALONyx.

Eurystomus calonyx, Hodgs.; Sharpe, Cat. B. Brit. Mus. xvii. p. 38, pl. ii. fig. 2 (1892); Styan, Ibis, 1893, p. 432.

Eurystomus orientalis, Hartl. (nec Linn.), Abh. nat. Ver. Bremen, xiv. p. 367 (1898).

Hoihow, North Hainan, 29th Sept. (Styan).

139. SCOPS LẸMPIJI.

Ephialtes lettia, Swinhoe (nec Hodgs.), Ibis, 1870, p. 88.

Ephialtes umbratilis, Swinhoe, Ibis, 1870 , p. 342, footnote.

Scops lempiji, Blyth; Sharpe, Cat. B. Brit. Mus. ii. p. 91 (1875).

Scops umbratilis, Sharpe, Cat. B. Brit. Mus. ii. p. 93 (1875).

A male shot near Kiung-chu, North Hainan, February (Swinhoe). The type of E. umbratilis Swinh. is now in the British Museum Collection. It resembles dark Indian examples of S. lempiji and is perfectly similar to specimens of $S$. lempiji from Sadia, Assam, collected by Colonel Godwin-Austen.

\section{Ninox JaPonica.}

Ninox japonicus (T. \& S.) ; Swinh. Ibis, 1870 , p. 88 ; Grant, Ibis, 1896, p. 111.

Ninox scutulata, Sharpe (nec Raff.), Cat. B. Brit. Mus. ii. p. 156 (1875).

Kiung-chu, North Hainan, 2nd April, and Haosuy, North-west Hainan, 29th March (Swinhoe).

The birds collected by Swinhoe are typical $N$. japonica.

141. *Glaucidium whitelyi.

Glaucidium whitelyi (Blyth); Sharpe, Cat. B. Brit. Mus. ii. p. 222 (1875). 
\%. "Iris straw-yellow; bill and feet greenish yellow."-J. $W$. Hainan.

This is the first time this Chinese species has been procured in

142. AsIo ACCIPITRINus.

Asio accipitrinus (Pall.); Sharpe, Cat. B. Brit. Mus. ii. p. 234 (1875).

Otus brachyotus, Steph.; Hartl. Abh. nat. Ver. Bremen, xii. pp. 299, 320 (1892).

Hartlaub records a specimen from North Hainan.

143. Circus spilonotus.

Circus spilonotus, Kaup ; Swinhoe, Ibis, 1870, p. 87 ; Sharpe, Cat. B. Brit. Mus. i. p. 58 (1874) ; Styan, Ibis, 1893, p. 433.

Swinhoe observed this species near the city of Ting-gan on the 15th of February and also in the neighbourhood of Kiung-chu in North Hainan.

Styan records it from the interior of South-west Hainan.

\section{Circus melanoleucus.}

Circus melanoleucus (Forst.); Sharpe, Cat. B. Brit. Mus.i. p. 61 (1874); Hartl. Abh. nat. Ver. Bremen, xii. pp. 299, 321 (1892).

Hartlaub records an adult male from North Hainan.

\section{Circus macrurus.}

Circus macrurus (Gmel.) ; Sharpe, Cat. B. Brit. Mus. i. p. 67 (1874) : Hartl. Abh. nat. Ver. Bremen, xii. pp. 299, 322 (1892), xiv. p. 369 (1898).

Hoihow, North Hainan, 19th December (Hartlaub).

146. *Lophospiza trivirgata.

Astur trivirgatus (Temm.); Sharpe, Cat. B. Brit. Mus. i. p. 105 (1874).

"Iris straw; cere greenish yellow; bill black, base of lower mandible bluish; feet dull yellow."-J. $W$.

I consider that Kaup is fully justified in distinguishing this bird from Astur, the long occipital crest and half-feathered tarsi being characters of importance.

This is the first time this species has been recorded from Hainan.

\section{Circus erruginosus.}

Circus ceruginosus (Linn.) ; Swinhoe, Ibis, 1870, p. 87 ; Sharpe, Cat. B. Brit. Mus. i. p. 69 (1874); Hartl. Abh. nat. Ver. Bremen, xiii. pp. 299, 321 (1892); Styan, Ibis, 1893, p. 433; Hartl. Abh. nat. Ver. Bremen, xiv. p. 369 (1898).

North Hainan, 15th February (Swinhoe \& Hartlaub).

Leimumon, northern slope of the mountains of South-west Hainan (Hartlaub \& Styan). 


\section{8. *Astur badius.}

Micronisus badius (Gmel.); Swinhoe, Ibis, 1870, p. 84.

Astur badius (Gmel.); Sharpe, Cat. B. Brit. Mus. i. p. 109 (1874).

Astur poliopsis, Hartl. (nec Hume), Abh. nat. Ver. Bremen, xii. pp. 299,322 (1892).

$J . W$.

"Iris straw-yellow ; bill black, base bluish; feet light yellow."-

Examples from Hainan have the crown of the head darker and the cheeks greyer than is the case in the majority of Indian examples ; there is, however, a female from Tipperah, in the British Museum Collection, which is absolutely indistinguishable from the two Hainan birds before me. The measurements are as follows:-Wing 8.8 to $8 \cdot 9$; tail 6.8 to $7 \cdot 1$ inches.

An adult male, Shuy-wei-sze, Central Hainan, 19th February (Swinhoe).

North Hainan (Hartlaub).

\section{ACCIPITER NISUs.}

Accipiter nisus (Linn.) ; Swinhoe, Ibis, 1870, p. 84; Sharpe, Cat. B. Brit. Mus. i. p. 132 (1874).

Swinhoe records the Common Sparrow-Hawk from Tai-ping-sze, Central Hainan, 20th February.

150. *ACCIPITER AFFINIS.

Accipiter virgatus (Temm.); Sharpe, Cat. B. Brit. Mus. i. p. 150 (1874) [part.].

Accipiter affinis, Hodgs.; Grant, Ibis, 1896, p. 107.

"Cere yellowish." $-J . W$.

Like Formosan examples, the Hainan Sparrow-Hawk belongs to the larger Himalayan form. Whitehead procured two adult females from the Five-Finger Mountains; this species had not previously been met with in Hainan.

\section{BUteo PLUMipes.}

Buteo japonicus, Swinhoe, Ibis, 1870 , p. 87.

Buteo plumipes (Hodgs.); Sharpe, Cat. B. Brit. Mus. i. p. 180 pl. vii. fig. 1 (1874); Styan, Ibis, 1893, p. 433.

Buteo hemilasius (Temm. \& Schl.); Sharpe, Cat. B. Brit. Mus. i. p. 182 (1874) ; Hartl. Abh. nat. Ver. Bremen, xii. pp. 299, 322 (1892).

Island of Naochow, 2nd February ; Ling-suy, South-east Hainan, 11th March; Heongpoo, West Hainan, 25th March (Swinkoe).

Interior of South-west Hainan (Styan).

North Hainan, 11th February (Hartlaub).

152. *SpizaËtus Nipalensis.

Spizaëtus nipalensis (Hodgs.); Sharpe, Cat. B. Brit. Mus. i. p. 267 (1874). 
o imm. "Iris yellow; bill black, base blue; cere and feet dull yellow." $-J . W$.

Recorded from Hainan for the first time.

153. SpiLoRnis Mela Notis.

Spilornis mutherfordi, Swinhoe, Ibis, 1870, p. 85.

Spilornis melanotis (Jerdon); Sharpe, Cat. B. Brit. Mus. i. p. 289 (1874); Hartl. Abh. nat. Ver. Bremen, xii. pp. 299, 322 (1892); Styan, Ibis, 1893, p. 433.

Spilornis cheela, Hartl. Abh. nat. Ver. Bremen, xiv. p. 369 (1898).

Forests of Central Hainan near Tai-ping-sze (Swinhoe).

North Hainan (Hartlaub).

Liu-wo-wan, northern slope of the mountains of South-west Hainan (Styan).

\section{Miluves melanotis.}

Milvus govinda, Swinhoe (nec Sykes), Ibis, 1870, p. 88 .

Milvus melanotis, T. \& S.; Sharpe, Cat. B. Brit. Mus. i. p. 324 (1874).

Abundant throughout Hainan (Swinhoe).

\section{Falco communis.}

Falco communis, Gmel.; Sharpe, Cat. B. Brit. Mus. i. p. 376 (1874); Hartl. Abh. nat. Ver. Bremen, xii. pp. 299, 320 (1892).

Hartlaub records an adult male from North Hainan, 12th December.

\section{Cerchneis tinnunculus.}

Tinnunculus alaudarius, Gray; Swinhoe, Ibis, 1870, p. 84.

Cerchneis tinnunculus (Linn.); Sharpe, Cat. B. Brit. Mus. i. p. 425 (1874).

Frequent throughout Hainan and in the small adjacent island of Nao-chu (Swinhoe).

\section{Pandion haliaëtus.}

Pandion haliaëtus (Linn.); Sharpe, Cat. B. Brit. Mus. i. p. 449 (1874); Swinhoe, Ibis, 1870 , p. 86.

Harbours of Hainan (Swinhoe).

\section{Polioa ËrUS HUMILIS.}

Polioaëtus ichthyaëtus, Horsf.; Sharpe, Cat. B. Brit. Mus. i. p. 452 (1874) [part.].

Polioaëtus plumbers (Hodgs.); Styan, Ibis, 1893, p. 434.

Polioaëtus humilis (Müll. \& Schl.); Blanf. Faun. Brit. Ind., Birds, iii. p. 371 (1895).

Liuwowan, northern slope of the mountains of South-west Hainan, 15th December (Styan). 


\section{Pelecanus philippensis.}

Pelecanus manillensis, Oates (nec Gmel.); Styan, Ibis, 1893, p. 434.

Pelecanus philippensis, Gmel.; Grant, Cat. B. Brit. Mus. xxvi. p. 471 (1898); Hartl. Abh. nat. Ver. Bremen, xiv. p. 380 (1898). Hoihow, North Hainan (Hartlaub).

160. Phalacrocorax carbo.

Phalacrocorax carbo (Linn.); Styan, Ibis, 1893, p. 434; Grant, Cat. B. Brit. Mus. xxvi. p. 340 (1898); Hartl. Abh. nat. Ver. Bremen, xiv. p. 380 (1898).

Hoihow, North Hainan (Hartlaub).

161. Sula sula.

Sula fusca, Vieill. ; Swinhoe, Ibis, 1870, p. 367.

Sula sula(Linn.); Grant, Cat. B. Brit. Mus. xxvi. p. 436 (1898). Seen by Swinhoe near Ting-gan, North Hainan.

162. Nettopus coromandelianus.

Nettopus coromandelianus (Gmel.); Styan, Ibis, 1893, p. 435 ; Salvad. Cat. B. Brit. Mus. xxvii. p. 68 (1895).

Nettapus coromandelicus, Hartl. Abh. nat. Ver. Bremen, xiv. p. 378 (1898).

Nodouho, interior of North Hainan (Hartlaub).

163. Mareca Penelope.

Anas penelope (Linn.); Swinhoe, Ibis, 1870, p. 366.

Mareca penelope, Salvad. Cat. B. Brit. Mus. xxvii. p. 227 (1895). North Hainan (Swinhoe).

164. Nettion CReCCA.

Anas crecca, Linn.; Swinhoe, 1bis, 1870, p. 366.

Nettion crecca, Salvad. Cat. B. Brit. Mus. xxvii. p. 243 (1895).

North Hainan (Swinhoe).

\section{Querquedula circia.}

Querquedula circia (Linn.); Styan, Ibis, 1893, p. 435 ; Salvad. Cat. B. Brit. Mus. xxvii. p. 293 (1895); Hartl. Abh. nat. Ver. Bremen, xiv. p. 379 (1898).

Hoihow, North Hainan (Styan \& Hartlaub).

166. Ibis Mela Nocephala.

Ibis melanocephala (Lath.); Hartl. Abh. nat. Ver. Bremen, xii. pp. 299, 326 (1892); Styan, Ibis, 1893, p. 434 ; Sharpe, Cat. B. Brit. Mus. xxvi. p. 7 (1898); Hartl. Abh. nat. Ver. Bremen, xiv. p. 374 (1898).

Hoihow, North Hainan (Styan \& Hartlaub). 


\section{Leptoptilus Javanicus.}

Leptoptilus javanicus (Horsf.); Swinhoe, Ibis, 1870, p. 364 ; Sharpe, Cat. B. Brit. Mus. xxvi. p. 317 (1898).

Swinhoe observed this bird on several occasions in Central Hainan.

\section{Pseudotantalus leucocephalus.}

Pseudotantalus leucocephalus (Forst.); Sharpe, Cat. B. Brit. Mus. xxvi. p. 323 (1898).

Tantalus leucocephalus, Hartl. Abh. nat. Ver. Bremen, xiv. p. 373 (1898).

Hoikow, North Hainan (Hartlaub).

169. Ardea cinerea, Linn.; Swinhoe, Ibis, 1870 , p. 365 ; Hartl. Abh. nat. Ver. Bremen, xii. op. 299, 324 (1892); Sharpe, Cat. B. Brit. Mus. xxvi. p. 74 (1898).

Seen in all parts of the island (Swinhoe).

170. Herodias timoriensis.

Herodias alba, Swinhoe (nec Linn.), Ibis, 1870, p. 365.

Herodias timoriensis (Cuv.); Sharpe, Cat. B. Brit. Mus. xxvi. p. 98 (1898).

Common (Swinhoe).

171. Garzetta garzetta.

Herodias garzetta, (Linn.); Swinhoe, Ibis, 1870, p. 365.

Ardea garzetta, Hartl. Abh. nat. Ver. Bremen, xii. pp. 299, 325 (1892).

Garzetta garzetta, Sharpe, Cat. B. Brit. Mus. xxvi. p. 118 (1898). Common (Swinhoe).

\section{NyCTICORAX NYCTICORAX.}

Nycticorax griseus, Linn. ; Swinhoe, Ibis, 1870 , p. 365 ; Styan, Ibis, 1893 , p. 434 ; Hartl. Abh. nat. Ver. Bremen, xiv. p. 373 (1898).

Nycticorax nycticorax, Sharpe, Cat. B. Brit. Mus. xxvi. p. 146 (1898).

Often seen in large flocks (Swinhoe).

Hoihow, North Hainan (Styan \& Hartlaub).

173. *Nycticorax magnifica. (Plate XXXIII.)

Nycticorax magnifica, Grant, Ibis, 1899, p. 586.

This species is most nearly allied to N. leuconotus (Wagl.), but differs chiefly in the following particulars:-The back is uniform brown like the wings; some of the concealed feathers of the lower back have a subterminal oval white spot at the extremity; a white band runs from behind the eye to the base of the long black crest (3 inches in length); the chin, throat, and fore part of the sides

Proc. Zoou. Soc.-1900, No. XXXIII. 
of the neck are white; the hinder parts of the sides of the neck chestnut; the middle of the fore-neck reddish brown, widely edged on either side with black; some of the intermediate feathers with pale buff middles; the rest of the underparts white, with wide irregular margins of reddish brown; and the thighs are dark reddish brown on the outer and white on the inner aspect.

"Iris dark brown; skin round the eye and base of bill sulphur greenish yellow; rest of bill black ; feet pea-green."-J. W.

Total length about 20 inches; culmen 3.1 ; wing 11.9 ; tail 4.9 ; tarsus $2 \cdot 95$.

This magnificent Night-Heron is not very closely allied to any known form; the style of the coloration of the lower parts is most like that of Gorsachius melanolophus.

Hab. Five-Finger Mountains, interior of Hainan.

\section{4. *ARdeola bacohus.}

Ardeola prasinosceles, Swinhoe, Ibis, 1870, p. 365 ; Styan, Ibis, 1893, p. 434.

Ardeola bacchus (Bonap.); Sharpe, Cat. B. Brit. Mus. xxvi. p. 211 (1898).

"A male in changing plumage has the iris straw-yellow; bill at base and skin round eye yellowish green, remainder of bill black; feet dull yellow."- $J$. $W$.

Abundant about paddy-fields and moist places (Swinhoe).

175. Ardenta sinensis.

Ardetta sinensis (Gmel.); Styan, Ibis, 1893, p. 434; Sharpe, Cat. B. Brit. Mus. xxvi. p. 227 (1898).

Recorded from Hainan by Styan.

176. Dupetor Flavicollis.

Ardetta flavicollis (Lath.); Styan, Ibis, 1893, p. 434.

Dupetor flavicollis (Lath.); Sharpe, Cat. B. Brit. Mus. sxvi. p. 247 (1898).

Recorded by Styan from Hainan.

177. Grus Grus.

Grus cinerea, Meyer \& Wolf; Swinhoe, Ibis, 1870, p. 362.

Grus lilfordi, Sharpe, Cat. B. Brit. Mus. xxiii. p. 252 (1894).

Common in plains and open country (Swinhoe).

178. Arenaria interpres.

Strepsilas interpres (Linn.); Swinhoe, Ibis, 1870, p. 361 ; Hartl. Abh. nat. Ver. Bremen, xii. pp. 300, 332 (1892); Styan, Ibis, 1893 , p. 436 ; Hartl. Abh. nat. Ver. Bremen, xiv. p. 375 (1898).

Arenaria interpres (Linn.); Sharpe, Cat. B. Brit. Mus. xxiv. p. 92 (1896).

Common at Poochin River, North-west Hainan, 5th March (Swinhoe).

Hoihow, North Hainan (Hartlaub). 
179. Hoplopterus ventralis.

Hoplopterus ventralis (Wagl.); Swinhoe, Ibis, 1870, p. 361 ; Sharpe, Cat. B. Brit. Mus. xxiv. p. 159 (1896).

Procured at Lingshuy, S.E. Hainan, 18th March (Swinhoe).

\section{Charadrius dominicus.}

Charadrius longipes, Temm.; Swinhoe, Ibis, 1870, p. 360.

Charadrius fulvus, Gmel.; Hartl. Abh. nat. Ver. Bremen, xii. pp. 300, 331 (1892) ; Styan, Ibis, 1893, p. 436 ; Hartl. Abh. nat. Ver. Bremen, xiv. p. 374 (1898).

Charadrius dominicus, P. L. S. Müll.; Sharpe, Cat. B. Brit. Mus. xxiv. p. 195 (1896).

West Hainan, 21st-23rd March, and Hoihow, North Hainan, 2nd April (Swinhoe).

Interior of North Hainan (Hartlaub).

\section{1. ОсптноDromus GeOFFroyi.}

Agralitis geoffroyi, Wagl.; Swinhoe, Ibis, 1870, p. 360.

Charadrius geoffroyi, Styan, Ibis, 1893, p. 436.

Ochthodromus geoffroyi, Sharpe, Cat. B. Brit. Mus. xxiv. p. 217 (1896); Hartl. Abh. nat. Ver. Bremen, xiv. p. 374 (1898).

A specimen from Paklai, West Hainan (Swinhoe).

Hoihow, North Hainan, 11th December (Hartlaub).

182. Ochthodromus Mongolicus.

Egialitis mongolicus (Pall.); Swinhoe, Ibis, 1870, p. 360.

Charadrius mongolicus, Styan, Ibis, 1893, p. 436.

Ochthodromus mongolus, Sharpe, Cat. B. Brit. Mus. xxiv. p. 223 (1896).

Ochthodromus mongolicus, Hartl. Abh. nat. Ver. Bremen, xiv. p. 374 (1898).

Chillan River, N.E. Hainan, 7th March, and Hungpe, N.W. Hainan, 30th March (Swinhoe).

Hoihow, North Hainan, 10th December (Hartlaub).

183. ※getalitis dubia.

AEgialitis intermedius (Ménétr.); Swinhoe, Ibis, 1870, p. 361. (1896).

Égialitis dubia (Scop.); Sharpe, Cat. B. Brit. Mus. xxiv. p. 263

Recorded from Hainan by Swinhoe.

\section{Egitalitis ALEXaNDRina.}

Egialitis dealbatus, Swinhoe, Ibis, 1870, p. 361.

Charadrius cantianus (Lath.); Styan, Ibis, 1893, p. 436.

Egialitis alexandrina (Linn.); Sharpe, Cat. B. Brit. Mus. xxiv.

p. 275 (1896).

Recorded from Hainan by Swinhoe. 
185. NuMENIUS PHEOPUS.

Numenius phceopus (Linn.); Hartl. Abh. nat. Ver. Bremen, xii. pp. 299, 327 (1892), xiv. p. 375 (1898); Sharpe, Cat. B. Brit. Mus. xxiv. p. 355 (1896).

Hoihow, North Hainan, 25th Nov. (Hartlaub).

186. Numenius arquatus.

Numenius major, Swinhoe, Ibis, 1870, p. 363.

Numenius arquatus (Linn.); Sharpe, Cat. B. Brit. Mus. xxiv. pp. 341, 753 (1896).

Lingshuy, South-east Hainan, 11th March (Swinhoe).

Hoihow, North Hainan, Feb.-April (Swinhoe).

187. Numenius Variegatus.

Numenius variegatus (Scop.); Styan, Ibis, 1893, p. 437 ; Sharpe, Cat. B. Brit. Mus. xxiv. p. 361 (1896); Hartl. Abh. nat. Ver. Bremen, xiv. p. 375 (1898).

Hoihow, North Hainan (Hartlaub \& Styan).

188. Limosa NOV Æ ZEALANdiא.

Limosa uropygialis, Gould; Swinhoe, Ibis, 1870, p. 362.

Limosa nova zealandice, Gray; Sharpe, Cat. B. Brit. Mus. xxiv. p. 377 (1896).

Limosa baueri, Naum.; Hartl. Abh. nat. Ver. Bremen, xiv. p. 376 (1898).

Hungpe, North-west Hainan, 30th March (Swinhoe).

Hoihow, North Hainan, Feb. and April (Swinhoe \& Hartlaub).

189. Limosa limosa.

Limosa melanuroides, Gould; Styan, Ibis, 1893, p. 437.

Limosa limosa (Linn.); Sharpe, Cat. B. Brit. Mus. xxiv. p. 381 (1896).

Limosa melanura (Leisl.); Hartl. Abh. nat. Ver. Bremen, xiv. p. 375 (1898).

Hoihow, North Hainan (Styan \& Hartlaub).

190. Totanus fuscus.

Totanus fuscus (Linn.); Hartl. Abh. nat. Ver. Bremen, xii. pp. 299, 328 (1892); Styan, Ibis, 1893, p. 437 ; Sharpe, Cat. B. Brit. Mus. xxiv. p. 409 (1896).

Hoihow, North Hainan, 31st January (Hartlaub \& Styan).

\section{Totanus CalidRis.}

Totanus calidris (Linn.); Swinhoe, Ibis, 1870, p. 364; Hartl. Abh. nat. Ver. Bremen, xii. pp. 299, 328 (1892); Sharpe, Cat. B. Brit. Mus. xxiv. p. 414 (1896).

Hoihow, North Hainan, 5th February and 9th December (Swinhoe \& Hartlaub). 
192. Totanus stagnatilis.

Totanus stagnatilis, Bechst.; Swinhoe, Ibis, 1870, p. 364 ; Hartl. Abh. nat. Ver. Bremen, xii. pp. 299, 328 (1892) ; Styan, Jbis, 1893, p. 437 ; Sharpe, Cat. B. Brit. Mus. xxiv. p. 422 (1896); Hartl. Abh. nat. Ver. Bremen, xiv. p. 376 (1898).

Hoihow, North Hainan, December, February, April (Swinhoe \& Hartlaub).

\section{Totanus glareola.}

Totanus glareola (Gmel.); Swinhoe, Ibis, 1870, p. 363 ; Hartl. Abh. nat. Ver. Bremen, xii. pp. 299, 328 (1892).

Rhyacophilus glareola (Gm.); Sharpe, Cat. B. Brit. Mus. xxiv. p. 491 (1896).

Kiung-chu-fu, North Hainan, 2nd April (Swinhoe).

\section{Squatarola helvetica.}

Squatarola helvetica (Linn.); Swinhoe, Ibis, 1870, p. 360 ; Hartl. Abh. nat. Ver. Bremen, xii. pp. 300, 331 (1892); Sharpe, Cat. B. Brit. Mus. xxiv. p. 436 (1896); Hartl. Abh. nat. Ver. Bremen, xiv. p. 374 (1898).

Charadrius helveticus, Linn.; Styan, Ibis, 1893, p. 436.

Hungpe Lagoon, West Hainan, 30th March (Swinhoe).

Hoihow, North Hainan, 12th December (Hartlaub).

\section{Tringoides hypoledcus.}

Tringoides hypoleucus (Linn.); Swinhoe, Ibis, 1870, p. 363; Sharpe, Cat. B. Brit. Mus. xxiv. p. 456 (1896).

Actitis hypoleucus (Linn.); Hartl. Abh. nat. Ver. Bremen, xii. pp. 299 (1892).

Totanus hypoleucus, Hartl. Abh. nat. Ver. Bremen, xii. p. 328 (1892).

Common everywhere (Swinhoe).

\section{Terekia cinerea.}

Totanus terekius (Lath.); Hartl. Abh. nat. Ver. Bremen, xii. p. 328 (1892).

Terekia cinerea (Güld.); Hartl. Abh. nat. Ver. Bremen, xii. p. 299 (1892) ; Sharpe, Cat. B. Brit. Mus. xxiv. p. 474 (1896). Hoihow, North Hainan, 17th December (Swinhoe).

197. Glottis nebularius.

Totanus glottis (Lath.); Swinhoe, Ibis, 1870, p. 364; Styan, Ibis, 1893 , p. 437 ; Hartl. Abh. nat. Ver. Bremen, xiv. p. 376 (1898).

Glottis nebularius (Gunner); Sharpe, Cat. B. Brit. Mus. xxiv. p. 481 (1896).

Very common about Hoihow, February (Swinhoe \& Hartlaub). 


\section{CaLidris arenaria.}

Calidris arenaria (Linn.) ; Swinhoe, Ibis, 1870, p. 363 ; Styan, Ibis, 1893 , p. 437 ; Sharpe, Cat. B. Brit. Mus. xxiv.p. 526(1896); Hartl. A bh. nat. Ver. Bremen, xiv. p. 375 (1898).

Hungpe, North-west Hainan (Swinhoe).

Hoihow, North Hainan (Hartlaub).

199. EURHYNORHYNCHUS PYGMAUS.

Eurhynorhynchus pygmaus (Linn.); Hartl. Abh.nat.Ver. Bremen, xii. pp. 300,330 (1892); Styan, Ibis, 1893, p. 437 ; Sharpe, Cat. B. Brit. Mus. xxiv. p. 535 (1896); Hartl. Abh. nat. Ver. Bremen, xiv. p. 377 (1898).

Hoihow, North Hainan (Hartlaub).

200. Tringa RUFicollis.

Tringa albescens, Temm.; Swinhoe, Ibis, 1870, p. 363.

Tringa ruficollis, Pall.; Styan, Ibis, 1893, p. 437.

Limonites ruficollis (Pall.); Sharpe, Cat. B. Brit. Mus. xxiv. p. 545 (1896).

Hungpe, North-west Hainan, 30th March (Swinhoe).

201. Tringa temmincki.

Tringa temmincki, Leisl.; Hartl. Abh. nat. Ver. Bremen, xii. pp. 300,329 (1892), xiv. p. 377 (1898).

Limonites temmincki (Leisl.); Sharpe, Cat. B. Brit. Mus. xxiv. p. 555 (1896).

Hoihow, North Hainan, 25th November (Hartlaub).

202. Tringa subarquata.

Tringa subarcuatus (Güld.); Styan, Ibis, 1893, p. 437.

Ancylochilus subarquatus (Güld.); Sharpe, Cat. B. Brit. Mus. xxiv. p. 586 (1896).

Tringa subarquata, Hartl. Abh. nat. Ver. Bremen, xii. pp. 300, 329 (1892), xiv. p. 376 (1898).

Hoihow, North Hainan, 17th December (Hartlaub).

203. Tringa canutus.

Tringa canutus, Linn.; Hartl. Abh. nat. Ver. Bremen, xii. pp. 300, 329 (1892); Sharpe, Cat. B. Brit. Mus. xxiv. p. 593 (1896).

North Hainan, 17th December.

204. Tringa crassirostris.

Tringa crassirostris, Temm. \& Schleg.; Hartl. Abh. nat. Ver. Bremen, xii.pp. 300, 329 (1892); Styan, Ibis, 1893, p. 436 ; Sharpe, Cat. B. Brit. Mus. xxiv. p. 600 (1896); Hartl. Abh. nat. Ver. Bremen, xiv. p. 376 (1898).

Hoihow, North Hainan, 24th November, 16th December, and 26th January (Hartlaub). 


\section{TRINGa alpina.}

Tringa cinclus (Linn.); Hartl. Abh. nat. Ver. Bremen, xii. pp. 300, 329 (1892); Styan, Ibis, 1893, p. 437.

Tringa alpina (Linn.); Swinhoe, Ibis, 1870, p. 363 ; Hartl. Abh. nat. Ver. Bremen, xiv. p. 377 (1898).

Pelidna alpina, Sharpe, Cat. B. Brit. Mus. xxxiv. p. 602 (1896).

Hoihow, North Hainan, 11th December and 15th January (Swinhoe \& Hartlaub).

\section{Limicola PLATYRHYNCHA.}

Tringa platyrkyncha, Temm.; Swinhoe, Ibis, 1870, p. 363; Styan, Ibis, 1893 , p. 437.

Limicola platyrhyncha (Temm.); Sharpe, Cat. B. Brit. Mus. xxiv. p. 612 (1896).

Hoihow, North Hainan, 5th February (Swinhoe).

207. Gallinago stenura.

Gallinago stenura (Bonap.); Swinhoe, Ibis, 1870, p. 362 ; Hartl. Abh. nat. Ver. Bremen, xii. pp. 300, 330 (1892); Styan, Ibis, 1893, p. 436 ; Sharpe, Cat. B. Brit. Mus. xxiv. p. 619 (1896).

Common throughout Hainan (Swinhoe).

208. Gallinago gallinago.

Gallinago scolopacina, Bonap.; Swinhoe, Ibis, 1870, p. 362.

Gallinago gallinago, Sharpe, Cat. B. Brit. Mus. xxiv. p. 633 (1896).

Common near Kiung-chu, North Hainan, February (Swinhoe).

209. Scotopax RUSTICULA.

Scolopax rusticula (Linn.); Styan, Ibis, 1893, p. 671; Sharpe, Cat. B. Brit. Mus. xxiv. p. 671 (1896); Hartl. Abh. nat. Ver. Bremen, xiv. p. 375 (1898).

North Hainan (Hartlaub).

210. Rostratula capensis.

Rhynchcea bengalensis (Linn.); Swinhoe, Ibis, 1870, p. 362.

Rhynchcea capensis (Linn.); Hartl. Abh. nat. Ver. Bremen, xii. pp. 300, 331 (1892); Styan, Ibis, 1893, p. 436 ; Hartl. Abh. nat. Ver. Bremen, xiv. p. 375 (1898).

Rostratula capensis (Linn.); Sharpe, Cat. B. Brit. Mus. xxiv. p. 683 (1896).

Hoihow, North Hainan (Swinhoe \& Hartlaub).

211. Phalaropus hyperboreus.

Lobipes hyperboreus (Linn.) ; Swinhoe, Ibis, 1870, p. 363.

Phalaropus hyperboreus, Sharpe, Cat. B. Brit. Mus. xxiv.

p. 698 (1896).

Hungpe, North-west Hainan, 4th April (Swinhoe). 
212. Hydroprogne CASPIA.

Sterna caspia, Pall.; Swinhoe, Ibis, 1870, p. 366 ; Hartl. Abh. nat. Ver. Bremen, xii. pp. 300, 334 (1892).

Hydroprogne caspia, Saunders, Cat. B. Brit. Mus. xxv. p. 32 (1896).

Plentiful at Hoihow, North Hainan, Feb. to April (Swinhoe \& Hartlaub).

213. Sterna sinensis.

Sterna sinensis (Gmel.); Styan, Ibis, 1893, p. 437 ; Saunders, Cat. B. Brit. Mus. xxv. p. 113 (1896).

Sternula sinensis, Hartl. A bh. nat. Ver. Bremen, xiv. p. 380 (1898).

Hoihow, North Hainan (Hartlaub).

214. Sterna melanadchen.

Sterna melanauchen, Temm.; Swinhoe, Ibis, 1870, p. 367; Saunders, Cat. B. Brit. Mus. xxv. p. 126 (1896).

Hoihow Harbour, North Hainan (Swinhoe).

215. LaRUS SAUNDERSI.

Larus saundersi, Swinhoe; Hartl. Abh. nat. Ver. Bremen, xii. pp. 300, 334 (1892); Styan, Ibis, 1893, p. 437; Saunders, Cat. B. Brit. Mus. xxv. p. 183 (1896).

North Hainan (Hartlaub).

216. Larus RIDIBUndus.

Larus ridibundus, Linn.; Saunders, Cat. B. Brit. Mus. xxv. p. 207 (1896); Hartl. Abb. nat. Ver. Bremen, xiv. p. 379 (1898).

Hoihow, North Hainan (Hartlaub).

217. Larus canus.

Larus niveus, Pall.; Swinhoe, Ibis, 1870, p. 366.

Larus canus, Linn.; Saunders, Cat. B. Brit. Mus. xxv. p. 277 (1896).

Hoihow Harbour, North Hainan, and Hungpe, North-west Hainan, February to April (Swinhoe).

218. Podicipes PHILIPPENSIS.

Podiceps philippensis (Bonnat.) ; Swinhoe, Ibis, 1870, p. 366 ; Hartl. Abh. nat. Ver. Bremen, xii. pp. 300, 334 (1892).

Tachybaptes fluviatilis, Styan (nec Tunst.), Ibis, 1893, p. 437.

Podicipes philippensis, Grant, Cat. B. Brit. Mus. xxvi. p. 511 (1898).

Often seen (Swinhoe).

219. Gallindla chloropus.

Gallinula chloropus (Linn.); Hartl. Abb. nat. Ver. Bremen, 
xii. pp. 300, 332 (1892) ; Sharpe, Cat. B. Brit. Mus. xxiii. p. 169 (1894).

Recorded from North Hainan by Hartlaub.

220. Gallicrex cinereus.

Gallicrex cinereus (Gm.); Styan, Ibis, 1893, p. 436 ; Sharpe, Cat. B. Brit. Mus. xxiii. p. 183 (1894); Hartl. Abh. nat. Ver. Bremen, xiv. p. 378 (1898).

Hoihow, North Hainan (Hartlaub).

221. Fulica atra.

Fulica atra, Linn.; Hartl. Abh. nat. Ver. Bremen, xii. pp. 300, 332 (1892); Sharpe, Cat. B. Brit. Mus. xxiii. p. 210 (1894).

North Hainan (Hartlaub).

222. *TRERON NIPALENSIS.

Treron nipalensis (Hodgs.); Salvad. Cat. B. Brit. Mus. xxi. p. 34 (1893) ; Styan, Ibis, 1893, p. 435.

"Iris orange; bill pale yellow ; base of bill and feet orange red."-J. $W$.

Interior of South-west Hainan (Styan).

223. Osmotrenon Bicincta.

Osmotreron domvilii, Swinhoe, Ibis, 1870, p. 354; Styan, Ibis, 1893 , p. 435.

Osmotreron bicincta (Jerd.); Salvad. Cat. B. Brit. Mus. xxi. p. 57 (1893); Hartl. Abh. nat. Ver. Bremen, xiv. p. 370 (1898).

Interior of Hainan (Swinhoe).

224. Carpophaga onea.

Carpophaga sylvatica (Tick.) ; Swinhoe, Ibis, 1870, p. 355.

Carpophaga oenea, Salvad. Cat. B. Brit. Mus. xxi. p. 190 (1893). Shuy-wei-sze, Central Hainan, 18th February, and Hungpe, West Hainan, 30th March (Swinhoe).

225. *Carpophaga griseicapilla.

Carpophaga griseicapilla, Wald.; Salvad. Cat. B. Brit. Mus. xxi. p. 217 (1893).

"Iris pale bluish white; bill and feet dull red; tip of bill dull grey."-J. $W$.

Recorded from Hainan for the first time.

226. Columba punicea.

Columba punicea (Tick.); Salvad. Cat. B. Brit. Mus. xxi. p. 306 (1893).

Alsocomus puniceus, Tick.; Styan, Ibis, 1893, p. 435; Hartl. Abh. nat. Ver. Bremen, xiv. p. 370 (1898).

Nam-fung, interior of North Hainan (Styan \& Hartlaub). 


\section{7. *Macropygia MiNor.}

Macropygia tusatia, var. minor, Swinh. Ibis, 1870, p. 355.

Macropygia swinhoii, W. Ramsay, Ibis, 1890, p. 218 ; Salvad. Cat. B. Brit. Mus. xxi. p. 340 (1898); Styan, Ibis, 1893, p. 435 ; Hartl. Abb. nat. Ver. Bremen, xiv. p. 370 (1898).

Two specimens in the Whitehead collection have the somewhat smaller measurements of $M$. minor, but are identical in plumage with typical M. tusalia, the colour of the back, wings, and tail being absolutely similar. The female type of $M$. minor has the back unusually dark and almost devoid of all trace of rufous cross-bars. The pair of birds sent home by Whitehead are the first really fine specimens that have been brought to Europe, and they seem to show that though some examples of $M$. minor are darker than typical $M$. tusalia, others are indistinguishable in plumage, and only differ in their somewhat smaller size.

סे. Wing $7 \cdot 1$; tail $7 \cdot 2$ inches.

ㅇ. , $6 \cdot 8 ;, 6 \cdot 8$, ,

"Iris narrow, pale yellow" bill dusky black; feet coral-red."J. $W$.

Tai-ping-sze, Central Hainan, Nychow, South Hainan (Swinhoe). Nam-fung, interior of North Hainan, May (Styan \& Hartlaub).

228. TURTUR ORIENTALIs.

Turtur rupicola (Pall.); Swinhoe, Ibis, 1870, p. 356 ; Hartl. Abh. nat. Ver. Bremen, xii. pp. 299, 323 (1892); Styan, Ibis, 1893, p. 435 ; Hartl. Abh. nat. Ver. Bremen, xiv. p. 370 (1898).

Turtur orientalis (Lath.); Salvad. Cat. B. Brit. Mus. xxi. p. 403 (1893).

A few near Kiung-chu, February (Swinhoe).

229. TURTUR HUMHLIS.

Turtur humilis (Temm.); Swinhoe, Ibis, 1870, p. 356 ; Salvad. Cat. B. Brit. Mus. xxi. p. 434 (1893); Styan, Ibis, 1893, p. 435.

Obtained at Kiung-chu, 10th February, and occasionally seen in other parts of the island (Swinhoe).

230. *TURTUR CHINENSIS.

Turtur chinensis (Scop.); Swinhoe, Ibis, 1870, p. 356; Hartl. Abh. nat. Ver. Bremen, xii. pp. 299, 324 (1892); Salvad. Cat. B. Brit. Mus. xxi. p. 439 (1893).

"Iris pale brownish yellow ; bill black; feet dull coral-red."J. $W$.

Found everywhere (Swinhoe).

231. Chalcophaps iNdica.

Chalcophaps indica (Linn.); Swinhoe, Ibis, 1870, p. 356 ; Hartl. Abh. nat. Ver. Bremen, xii. pp. 299, 323 (1892); Salvad. Cat. B. Brit. Mus. xxi. p. 514 (1893); Styan, Ibis, 1893, p. 435 ; Hartl. Abh. nat. Ver. Bremen, xiv. p. 370 (1898). 
Once obtained at Shuy-wei-sze, Central Hainan, 27th February (Swinhoe).

Lui-wo-wan, northern slope of the mountains of South-west Hainan; Nodouha, interior of North Hainan, and the Hummocks, near the coast of North Hainan (Styan \& Hartlaub).

232. TURN1X DUSSUMIERI.

Turnix dussumieri (Temm.); Hartl. Abh. nat. Ver. Bremen, xii. pp. 299, 324 (1892); Grant, Cat. B. Brit. Mus. xxii. p. 540 (1893).

Hartlaub records a specimen from North Hainan on the 24th March.

233. Caccabis chukar.

Caccabis chukar (Gray); Grant, Cat. B. Brit. Mus. xxii. p. 113 (1893); Hartl. Abh. nat. Ver. Bremen, xiv. p. 371 (1898).

Hartlaub records a pair from Hainan.

234. *Francolinds chinensis.

Francolinus sinensis, Swinhoe, Ibis, 1870, p. 359 ; Hartl. Abh. nat. Ver. Bremen, xiv. p. 372 (1898).

Francolinus chinensis (Osbeck); Hartl. Abh. nat. Ver. Brem. xii. pp. 299, 324 (1892); Grant, Cat. B. Brit. Mus. xxii. p. 136 (1893); Styan, Ibis, 1893, p. 435.

"Iris hazel; bill dusky black, base whitish; feet orange-yellow."-J. $W$.

Common everywhere (Swinhoe).

235. ARBoricola ARDENs.

Arboricola ardens, Styan, Ibis, 1893, p. 436, pl. xii.; Grant, Cat. B. Brit. Mus. xxii. p. 210 (1893).

The only specimen known of this remarkable Tree-Partridge was obtained at Luiwowan, on the northern slope of the mountains of South-west Hainan, in the month of December.

236. CotURnix COTURNIx.

Coturnix communis, Bonn.; Hartl. Abh. nat. Ver. Bremen, xii. pp. 299, 324 (1892).

Coturnix coturnix (Linn.) ; Grant, Cat. B. Brit. Mus. xxii. p. 231 (1893).

North Hainan, 29th January (Hartlaub).

237. Excalfactoria chinensis.

Excalfactoria chinensis, Swinhoe (nec Linn.), Ibis, 1870, p. 360 ; Grant, Cat. B. Brit. Mus. xxii. p. 250 (1893).

Seen by Swinhoe, but not obtained. It is quite possible that the Hainan bird should be referred to the subspecies $E$. lineata.

238. *Genn aus whiteheadi. (Plate XXXIV.)

Gennoeus whiteheadi, Grant, Ibis, 1899, p. 586.

The male of this remarkably fine species of Silver Pheasant 
is most nearly allied to G. nycthemerus, but, as may be seen from the accompanying drawing (Plate XXXIV.), differs conspicuously in many important particulars.

Crown black with a slight blue gloss; nuchal erest rather long (2.5 inches) and similarly coloured, the longer feathers being decomposed.

Adult male. Nape and upper mantle pure white; each feather of the lower mantle, back, rump, and shorter upper tail-coverts with one black submarginal band on each web, forming an arrowhead black marking, which gradually increases in width towards the tail, most of the feathers being also narrowly fringed with black. Wing-coverts similar, but with the black markings much coarser. Longer upper tail-coverts and secondaries very boldly marked with successive black arrow-heads. Primary-quills black, with wide oblique white markings. Middle tail-feathers pure white; second and third pairs white, with wide (about 0.5 inch) oblique black bands on the outer web; the latter pair with some irregular black marking on the inner web also; remaining pairs white, with wide oblique black bands on both webs forming an irregular arrow-head pattern. Underparts black, some of the feathers of the sides with narrow white middles. Iris brownish yellow; naked wattle and skin on sides of face scarlet; bill greenish white ; legs coral-red.

Total length 35 inches ; wing $9 \cdot 4$; tail 20 ; tarsus $3 \cdot 15$.

Adult female. Most nearly resembles the female of $G$. andersoni, but is much darker. The feathers of the neck and mantle mostly black with wide white shaft-streaks; the underparts, including the under tail-coverts, similar, but with wider white middles. Outer tail-feathers uniform dark chestnut, with indistinct vermiculations of black. Iris light brown; upper mandible greenish brown, lower dull green; naked skin on face red; legs and feet bright scarlet.

Total length 21.5 inches ; wing 8.1 ; tail 8.8 ; tarsus 2.9 .

Mr. Whitehead secured three adult males and one female of this splendid Silver Pheasant.

$H a b$. Five-Finger Mountains, interior of Hainan.

\section{Gallus gallus.}

Gallus fermigineus (Gmel.); Swinhoe, Ibis, 1870, p. 357; Styan, Ibis, 1893, p. 435 ; Hartl. Abh. nat. Ver. Bremen, xiv. p. 371 (1898).

Gallus gallus (Linn.); Grant, Cat. B. Brit. Mus. xxii. p. 344 (1893).

Gallus bankiva, Temm.; Hartl. Abh. nat. Ver. Bremen, xii. p. 324. Throughout Hainan (Swinhoe).

EXPLANATION OF THE PLATES.

Plate XXXIII.

Nycticorax magnifica, p. 493.

Plate XXXIV.

Gennceus whiteheadi, ơ ㅇ, p. 503. 


\section{$2 \mathrm{BHL}$ Biodiversity Heritage Library}

1900. "W. T. BLANFORD, Esq., LL.D., F.E.S., Vice-President, in the Chair." Proceedings of the Zoological Society of London 1900, 429-516.

https://doi.org/10.1111/j.1096-3642.1890.tb01723.x.

View This Item Online: https://www.biodiversitylibrary.org/item/97409

DOI: https://doi.org/10.1111/j.1096-3642.1890.tb01723.x

Permalink: https://www.biodiversitylibrary.org/partpdf/72568

\section{Holding Institution}

Natural History Museum Library, London

\section{Sponsored by}

Natural History Museum Library, London

\section{Copyright \& Reuse}

Copyright Status: Public domain. The BHL considers that this work is no longer under copyright protection.

This document was created from content at the Biodiversity Heritage Library, the world's largest open access digital library for biodiversity literature and archives. Visit BHL at https://www.biodiversitylibrary.org. 